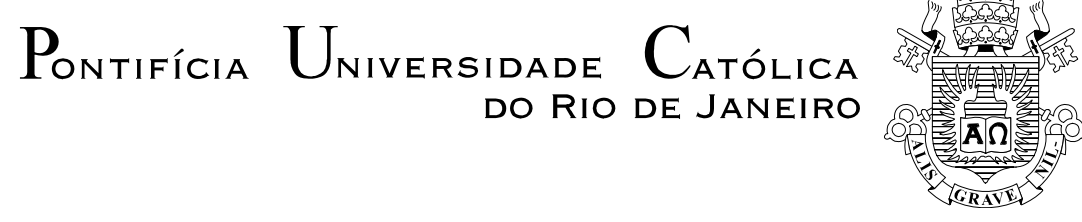

Rafael Soares Firmino

Situações Subjetivas Existenciais do Nascituro

Dissertação de Mestrado

Dissertação apresentada ao Programa de PósGraduação em Direito da PUC-Rio como requisito parcial para obtenção do título de Mestre em Direito.

Orientadora: Profa. Caitlin Sampaio Mulholland 
Pontifícia Universidade Católica $_{\text {a }}$

\section{Rafael Soares Firmino}

\section{Situações Subjetivas Existenciais do Nascituro}

Dissertação apresentada como requisito parcial para obtenção do título de Mestre pelo Programa de Pósgraduação em Direito do Departamento de Direito da PUCRio. Aprovada pela Comissão Examinadora abaixo assinada.

Prof ${ }^{\mathrm{a}}$ Caitlin Sampaio Mulholland

Orientadora

Departamento de Direito - PUC-Rio

Profa. Maria Celina Bodin de Moraes

Departamento de Direito - PUC-Rio

Prof. Carlos Edison do Rêgo Monteiro Filho

UERJ

Profa. Mônica Herz

Vice-Decana de Pós-Graduação do Centro de

Ciências Sociais - PUC-Rio

Rio de Janeiro, 08 de abril de 2014. 
Todos os direitos reservados. É proibida a reprodução total ou parcial do trabalho sem autorização da universidade, do autor e do orientador.

\section{Rafael Soares Firmino}

Pós-graduação em Direito Civil e Processo Civil pelas Faculdades Integradas de Caratinga - FIC (2007) e graduação em Direito pelas Faculdades Integradas de Caratinga - FIC (2004). É professor das Faculdades Doctum - Campus Manhuaçu desde 2008.

Ficha Catalográfica

Firmino, Rafael Soares.

Situações Subjetivas Existenciais do Nascituro./ Rafael Soares Firmino; orientadora: Caitlin Sampaio Mulholland 2014.

112 f. ; $30 \mathrm{~cm}$

Dissertação (mestrado)-Pontifícia Universidade Católica do Rio de Janeiro, Departamento de Direito, 2014.

Inclui bibliografia

1. Direito - Teses. 2. Nascituro. 3. personalidade jurídica. 4. capacidade jurídica. 5. direitos da personalidade. 6. dignidade da pessoa humana; 7. entes despersonificados.. I. Mulholland, Caitlin Sampaio. II. Pontifícia Universidade Católica do Rio de Janeiro. Departamento de Direito. III. Título. 
Aos amores da minha vida: Flavinha, Mateuzinho, Anninha e Lele. 


\section{Agradecimentos}

Agradeço, primeiramente, à querida professora Caitlin Sampaio Mulholland, que neste momento de descobertas e incertezas me ajudou a trilhar o caminho com tranquilidade e passos firmes.

À minha amada esposa Flávia que sabe o quanto sofremos e lutamos para conseguirmos esta vitória. Você sabe a importância que tem em minha vida, te amo muito!

Aos meus filhos Mateus, Anna Carolina e Letícia, primeiro peço desculpas pela minha ausência neste período, mesmo estando presente. Vocês, hoje, são tudo o que mais amo neste mundo.

Aos meus pais Bernardino e Inês que são espelho para qualquer ser humano e que contribuíram, não apenas em seus pensamentos e orações, mas em cada palavra de incentivo. Vocês são os melhores pais do mundo!!!

Ao meu irmão Bruno, minha sobrinha Lulu e à Roberta, melhores amigos. Amo vocês!!!

Ao Oscar Alexandre, meu sócio e irmão, e Daniel, primo e irmão, que muito contribuíram lendo meus trabalhos neste período e dividiram comigo a ideia. Valeu!!!

Aos amigos que ganhei no mestrado: Frederico, Humberto, Alessandra e Juliana. Conseguimos!!!

Aos amigos José Lúcio e Iana, muito obrigado por tudo o que fizeram por mim neste período!!!

Aos Professores Pedro Leitão e Cláudio Leitão, pelo incentivo.

Ao "Sô" Carlinhos pela ajuda e amizade.

Aos amigos e alunos da Faculdade Doctum de Manhuaçu, por tornar os meus dias mais prazerosos.

Enfim, a todos os meus amigos e familiares que de alguma maneira me ajudaram nesta caminhada.

VALEU!!! 


\section{Resumo}

Firmino, Rafael Soares. Mulholland, Caitlin Sampaio. Situações Subjetivas Existenciais do Nascituro. Rio de Janeiro, 2014. 112p. Dissertação de Mestrado - Departamento de Direito, Pontifícia Universidade Católica do Rio de Janeiro.

A presente dissertação tem como objetivo abordar o início da personalidade jurídica da pessoa, defendendo o reconhecimento do nascituro como um ente despersonificado, que não é detentor de personalidade jurídica, mas que o próprio ordenamento jurídico o trata como se fosse. Nesse contexto, o princípio da dignidade da pessoa humana identificado como cláusula geral dos direitos da personalidade embasa o reconhecimento do nascituro como sujeito de direito, pois se trata de princípio que é inerente a qualquer ser humano, e em alguns casos até a seres não humanos. Dessa forma, após compreender o princípio da dignidade da pessoa humana e os direitos da personalidade aplicáveis ao nascituro discute-se as teorias que procuram solucionar o problema da personalidade deste ente. Assim, a partir da identificação da tutela de direitos da personalidade, como o direito à vida, à integridade física, à saúde, à filiação, à adoção, ao dano moral, dentre outros, ao nascituro o próprio ordenamento jurídico, acompanhado da jurisprudência pátria, reconhece capacidade de direito a este ente. Portanto, aplicando hermenêutica civil-constitucional é possível, a partir do princípio da dignidade da pessoa humana, o reconhecimento do nascituro como sujeito de direito despersonificado, titular de direitos e deveres.

\section{Palavras-Chave}

Nascituro; personalidade jurídica; capacidade jurídica; direitos da personalidade; dignidade da pessoa humana; entes despersonificados. 


\section{Abstract}

Firmino, Rafael Soares. Mulholland, Caitlin Sampaio(Advisor). Existential Subjective Situations of the Unborn. Rio de Janeiro, 2014. 112p. MSc Dissertation - Departamento de Direito, Pontifícia Universidade Católica do Rio de Janeiro.

This thesis aims to address the begining of the legal personality of the person, and it advocates for the recognition of the unborn child as an despersonificated entity, which does not hold legal personality, but that the law itself treats it as if it were. In this context, the principle of human dignity identified as general clause of personal rights underlies the recognition of the unborn child as a subject of rights, because such principle is inherent in every human being, and in some cases, also not human beings. Thus, when understanding the principle of human dignity and personality rights applied to unborn, it discusses the theories that attempt to solve the problem of personality of this entity. Furthermore, by identifying the tutelage of personality rights such as the right to life, physical integrity, health, affiliation, adoption, moral damages, among others of the unborn, the law accompanied by the jurisprudence recognize the legal capacity of this entity. Therefore, when applying civil and constitutional hermeneutics from the principle of human dignity, it is possible to recognize the unborn child as a not personified subject of law that has rights and duties.

\section{Keywords}

Unborn; legal personality; legal capacity; personality rights; human dignity; not personified entity. 


\section{Sumário}

$\begin{array}{ll}\text { 1. Introdução } & 10\end{array}$

2 A Dignidade da Pessoa Humana e os Direitos da Personalidade. 13

2.1 O direito civil constitucional como instrumento de tutela das situações jurídicas existenciais. 13

2.2 A dignidade humana como cláusula geral de tutela da personalidade. $\quad 16$

2.2.1 Evolução e conteúdo da dignidade da pessoa humana 18

2.2.2 Conceito jurídico da dignidade humana 25

2.3 Pessoa, Personalidade e os Direitos da Personalidade no
Direito Brasileiro.

2.3.1 Direitos da Personalidade no Direito Brasileiro 31

2.3.2 Fonte dos direitos da personalidade e o direito geral da personalidade. 36

2.3.3 Personalidade e Capacidade 39

3 Do Nascituro $\quad 45$

3.1 Conceito de Nascituro $\quad 45$

3.1.1 Teoria Natalista $\quad 49$

3.1.2 Teoria da Concepção 52

3.1.3 Teoria da Concepção Condicionada 54

3.2 Teorias Análogas 56

3.2.1 Teoria dos Entes Despersonificados 56

3.2.2 Natureza Jurídica dos Animais 62

3.3 O elemento determinante para o reconhecimento dos sujeitos de direitos. 67

3.3.1 A Massa Falida $\quad 69$

$\begin{array}{ll}\text { 3.3.2 O Espólio } & 70\end{array}$

$\begin{array}{ll}\text { 3.3.3 O Condomínio } & 71\end{array}$

3.3.4 A Herança Jacente e Vacante $\quad 71$

$\begin{array}{ll}\text { 3.3.5 A Sociedade de Fato ou Irregular } & 71\end{array}$

3.3.6 Os animais $\quad 72$

$\begin{array}{ll}\text { 3.3.7 O nascituro como Ente Despersonificado } & 72\end{array}$

4 Das Tutelas Existenciais do Nascituro $\quad 77$

4.1 Direito à Vida $\quad 77$

4.2 Direito à Integridade Física $\quad 81$

4.3 Direito à filiação $\quad 83$

4.4 Direito à adoção

4.5 Direito a alimentos $\quad 89$

4.6 Direito a Reparação por Dano Moral 93

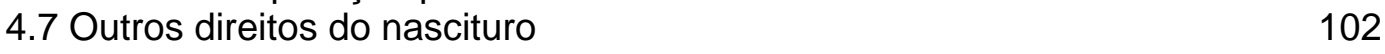

$\begin{array}{ll}\text { 5. Conclusão } & 104\end{array}$

$\begin{array}{ll}\text { 6. Referências Bibliográficas } & 108\end{array}$ 


\section{Lista de Tabelas}

Tabela 1 - Quadro de reconhecimento da natureza jurídica dos entes personificados e despersonificados. 


\section{1 \\ Introdução}

A presente dissertação estuda as Situações Subjetivas Existenciais do Nascituro e tem como objetivo analisar o conceito jurídico de pessoa, procurando identificar se os entes já concebidos no ventre materno, mas ainda não nascidos, detêm personalidade jurídica e/ou quais aspectos de proteção se aplicam a eles.

Investiga-se a natureza jurídica de tais entes sob o enfoque da dignidade da pessoa humana, uma vez que existem controvérsias na doutrina e na jurisprudência acerca da personalidade jurídica do nascituro.

Neste sentido, surge o problema da admissão de tutela existencial ao nascituro e se esta admissibilidade caracteriza o reconhecimento deste ente como detentor de personalidade jurídica, sendo resguardados seus direitos da personalidade.

A relevância do presente tema está no fato de que a personalidade jurídica do nascituro gera, até os dias de hoje, muita discussão, existindo enorme controvérsia acerca do reconhecimento, ou não, de seus direitos da personalidade.

Assim, a situação de estar o feto já concebido no ventre materno, mas ainda não nascido, gera grande debate em nossa doutrina e jurisprudência, pois, na atualidade, há uma série de relações jurídicas em que o nascituro encontra-se envolvido e sobre as quais o ordenamento jurídico não traz norma expressa.

O debate acerca do nascituro ser considerado uma pessoa titular de direitos e deveres na ordem jurídica trata-se de assunto de extrema importância para nossa sociedade, uma vez que todo ser humano tem o direito a uma vida digna.

Assim, a presente dissertação visa refletir sobre o reconhecimento dos direitos da personalidade ao ente que já foi concebido no ventre materno, mas que ainda não nasceu.

A análise dos direitos da personalidade é de extrema importância, uma vez que tais direitos referem-se aos chamados direitos essenciais da pessoa e são os que garantem o desenvolvimento pleno do ser humano.

A partir da mudança da perspectiva constitucional em nosso ordenamento jurídico, em que se coloca a pessoa acima do patrimônio, o princípio da dignidade da pessoa humana assentou as relações existenciais face às patrimoniais. 
Dessa forma, a consagração do princípio constitucional da dignidade da pessoa humana, que resultou na igualdade de direitos entre as pessoas, e na proteção de seus direitos, considerados inalienáveis, o caracterizou como uma cláusula geral dos direitos da personalidade.

Portanto, a partir das várias indagações surgidas em nosso ordenamento jurídico acerca da personalidade do nascituro, surgem algumas teorias que tratam do assunto e tentam solucionar o problema da personalidade deste ente, como a teoria natalista, a teoria condicionalista, a teoria concepcionista, bem como a teoria dos entes despersonificados ou despersonalizados.

Assim, para a análise da personalidade jurídica do nascituro serão fundamentais os estudos dos atuais contornos dados pela doutrina e pela jurisprudência aos direitos da personalidade, como também das teorias relacionadas à solução deste problema e das situações jurídicas nas quais o ordenamento jurídico reconhece o nascituro como titular de direitos.

No primeiro capítulo, será apresentado o princípio da dignidade da pessoa humana como uma cláusula geral de tutela da personalidade, apresentando a evolução, o conteúdo, o fundamento material e a definição deste princípio constitucional, que é a base para a sustentação dos direitos da personalidade.

Após a apresentação do princípio da dignidade da pessoa, como cláusula geral dos direitos da personalidade, com previsão no art. $1^{0}$, inciso III, da Constituição Federal, ainda no primeiro capítulo, serão apresentados os direitos da personalidade no direito brasileiro sob uma perspectiva civil-constitucional.

Será feita, também, uma análise da personalidade e da capacidade jurídicas, em que procurará definir o termo pessoa e apresentar as definições de personalidade jurídica e de capacidade, procurando desvinculá-las de conceitos jurídicos clássicos, de modo que se identifiquem melhores soluções às situações subjetivas nas quais o nascituro é titular.

A doutrina civilista brasileira tradicional trata a pessoa como um mero objeto, atrelando, necessariamente, a ideia de pessoa à de sujeito de direitos. Neste sentido, para um ente se tornar titular de direitos e deveres ele deve ser detentor de personalidade jurídica, ou seja, para o indivíduo adquirir capacidade é necessário que ele seja pessoa. Podendo-se afirmar que pessoa é o sujeito titular de relações jurídicas. 
Porém, o ordenamento jurídico brasileiro reconhece apenas duas espécies de entes detentores de personalidade jurídica: as pessoas naturais já nascidas e as pessoas jurídicas com seus atos constitutivos registrados nos órgãos competentes. Isto é, a partir de uma conceituação clássica de personalidade jurídica, apenas as pessoas personificadas (pessoas naturais e jurídicas) são titulares de direitos e deveres na ordem jurídica.

Existe, ainda, a capacidade, que, para a doutrina tradicional, trata-se de instituto proveniente da personalidade jurídica, sendo aquela um atributo desta. Entretanto, nos dias atuais, a capacidade não deve ser confundida com a personalidade jurídica, pois existem situações subjetivas existenciais, aplicadas a alguns entes despersonificados, nas quais a capacidade é reconhecida.

No segundo capítulo, será abordado o conceito de nascituro bem como as teorias tradicionais - natalista, da concepção condicional e concepcionista - que discutem e tentam solucionar o problema da personalidade deste ente.

Será feita, também, uma análise de teorias análogas que procuram solucionar o problema da personalidade jurídica de certos entes aos quais o direito reconhece a titularidade de direitos e deveres, mas não os considera pessoas, como a teoria dos entes despersonificados ou despersonalizados e as teorias que discutem a natureza jurídica dos animais. E a partir da análise dessas teorias, demonstrar uma solução mais avançada para o problema da personalidade jurídica do nascituro.

O terceiro e último capítulo analisará situações subjetivas existenciais em que o ordenamento jurídico e a jurisprudência reconhecem o nascituro como titular de direitos personalíssimos. Confirmando-se a teoria dos entes despersonificados como a mais apropriada para solucionar o problema da personalidade do nascituro. Isto porque este ente não é detentor de personalidade jurídica, conforme prevê o art. $2^{\circ}$ do Código Civil, mas, a partir da aplicação de uma hermenêutica civil-constitucional, ele é detentor de capacidade de direito. 


\section{A Dignidade da Pessoa Humana e os Direitos da Personalidade.}

\section{1 \\ O direito civil constitucional como instrumento de tutela das situações jurídicas existenciais.}

Atualmente, a Constituição Federal é considerada o epicentro do Direito Privado, mas nem sempre foi este o entendimento carregado pela doutrina brasileira. O Código Civil, até a vigência da Constituição Federal de 1988, sempre foi considerado o dispositivo mais importante do direito brasileiro, reconhecido como a "Constituição do direito privado", monopolizando as relações privadas e regulando os sujeitos de direito.

Segundo Fernanda Borghetti Cantali “a pessoa abstratamente considerada era identificada com o sujeito de direito definido como aquele que é capaz de adquirir direitos e contrair obrigações, ou seja, aquele indivíduo que voluntariamente compra, vende, contrata, testa, etc”². Tal afirmativa revela que o direito civil tratava de um ramo de direito que reconhecia o individualismo e o patrimônio $^{3}$ em detrimento dos valores subjetivos existenciais ${ }^{4}$.

\footnotetext{
${ }^{1}$ TEPEDINO, Gustavo. Temas de direito civil. $3^{\mathrm{a}}$ edição atualizada. - Rio de Janeiro: Renovar, 2004, p. 2.

${ }^{2}$ CANTALI, Fernanda Borghetti. Direitos da personalidade: disponibilidade relativa, autonomia privada e dignidade humana. - Porto Alegre: Ed. Livraria do Advogado, 2009, p. 40.

${ }^{3}$ O Código Civil de 1916, bem se sabe, é fruto da doutrina individualista e voluntarista que, consagrada pelo Código de Napoleão e incorporada pelas codificações posteriores, inspiraram o legislador brasileiro quando, na virada do século, redigiu o nosso primeiro Código Civil. Àquela altura, o valor fundamental era o indivíduo. O direito privado tratava de regular, do ponto de vista formal, a atuação dos sujeitos de direito, notadamente o contratante e o proprietário, os quais, por sua vez, a nada aspiravam senão ao aniquilamento de todos os privilégios feudais: poder contratar, fazer circular as riquezas, adquirir bens como expansão da própria inteligência e personalidade, sem restrições ou entraves legais. Eis aí a filosofia do século XIX que marcou a elaboração do tecido normativo consubstanciado no Código Civil de 1916. TEPEDINO, Gustavo. Temas de direito civil. $3^{\text {a }}$ edição atualizada. - Rio de Janeiro: Renovar, 2004, p. 2.

${ }^{4}$ Para Pietro Perlingieri as situações subjetivas existenciais (direitos da personalidade) são vistas como uma série aberta de hipóteses, de fato merecedoras de tutela, e tratam de questões atinentes à condição existencial do homem, pessoa humana, colocado no centro do ordenamento jurídico. "De um ponto de vista objetivo, a situação é um interesse que, essencial à sua existência, constitui o seu núcleo vital e característico. Interesse que pode ser ora patrimonial, ora de natureza pessoal e existencial, ora um e outro juntos, já que algumas situações patrimoniais são instrumentos para a realização de interesses existenciais ou pessoais. No ordenamento dito privatístico encontram espaço sejam situações patrimoniais e entre essas a propriedade, o crédito, a empresa, a iniciativa econômica privada; sejam aquelas não patrimoniais (os chamados direitos da personalidade) às quais cabe, na hierarquia das situações subjetivas e dos valores, um papel primário". PERLINGIERI, Pietro. Perfis de direito civil. Tradução de Maria Cristina De Cicco. $2^{\mathrm{a}}$ ed. - Rio de Janeiro: Renovar, 2002, p. 106.
} 
Encontrava-se arraigada à ideia de que as relações entre particulares eram estabelecidas e tuteladas apenas pelo Código Civil e pela legislação de ordem privada. O Direito Público e o Direito Privado eram considerados como áreas estanques, admitindo-se a interferência do Estado nas relações particulares apenas para manter a coexistência pacífica entre os indivíduos, resolvendo os conflitos travados entre os particulares e entre estes e o próprio Estado.

Esse quadro começou a modificar no final do século XIX e início do século XX, como afirma Maria Celina Bodin de Moraes: “o breve século XX representou um importante momento de transição na teoria do direito”, ${ }^{5}$, pois, após eclodirem movimentos sociais e uma crescente industrialização em todo o mundo no final do século XIX, tornou-se inevitável, principalmente após as duas grandes guerras mundiais, a intervenção do Estado na economia, através da elaboração de legislações especiais. ${ }^{6}$

O Estado, após eclodir a Primeira Guerra Mundial, movimenta-se criando legislações extravagantes com a finalidade de regular situações que não eram previstas pela codificação civilista, delineando uma maior intervenção do Estado nas relações privadas. ${ }^{7}$

Com a criação de várias leis extravagantes que regulam relações privadas não previstas pelo Código Civil, este começa a perder a sua característica de norma exclusiva a regular as relações entre particulares, tornando-se apenas um direito comum que aplica suas normas de modo uniforme a todas as relações jurídicas privadas, baseado no individualismo e no patrimonialismo. ${ }^{8}$

Após a segunda guerra mundial tornou-se imperioso que o direito criasse novos instrumentos que revertessem o quadro alcançado pelos regimes totalitários, deixando de lado o pensamento individualista e patrimonialista passando a se ater mais ao ser humano. ${ }^{9}$

\footnotetext{
${ }^{5}$ MORAES, Maria Celina Bodin de. O jovem direito civil constitucional. In: revista eletrônica de direito civil. Ano $1 \mathrm{n}^{0}$ 1/2012. Disponível em http://civilistica.com/o-jovem-direito-civilconstitucional. Acessado em 12 de janeiro de 2014 às 23:00.

${ }^{6}$ TEPEDINO, Gustavo. Temas de direito civil. $3^{\mathrm{a}}$ edição atualizada. - Rio de Janeiro: Renovar, 2004, p. 4-5.

7 TEPEDINO, Gustavo. Temas de direito civil. $3^{\mathrm{a}}$ edição atualizada. - Rio de Janeiro: Renovar, 2004, p. 4-5.

8 TEPEDINO, Gustavo. Temas de direito civil. $3^{\mathrm{a}}$ edição atualizada. - Rio de Janeiro: Renovar, 2004, p. 5.

${ }^{9}$ MORAES, Maria Celina Bodin de. O jovem direito civil constitucional. In: revista eletrônica de direito civil. Ano 1 n ${ }^{0}$ 1/2012. Disponível em http://civilistica.com/o-jovem-direito-civilconstitucional. Acessado em 12 de janeiro de 2014 às 23:00.
} 
As constituições, que até aquele momento eram apenas cartas políticas, começaram a reconhecer e trazer para seu corpo institutos que eram tratados somente pelo direito privado, dando ensejo à Constitucionalização do Direito Civil. $^{10}$

Assim, as constituições do pós-guerra, passaram a proteger, prioritariamente, o ser humano dotado de dignidade e não mais o patrimônio.

Começam a surgir diversas constituições democráticas permeadas por valores sociais, abrindo novos paradigmas na ordem constitucional.

Os textos constitucionais, gradativamente, definem princípios e institutos que até então eram reservados ao Código Civil, deixando os princípios constitucionais de serem meros princípios políticos, e passam a ser entendidos como necessariamente presentes em todo o ordenamento.

As Constituições deixam de ser meras cartas políticas do Estado e passam a ser do cidadão, através de "um amplo rol de direitos e garantias fundamentais, precedido da enunciação de princípios que contém valores caros a um Estado Democrático de Direito”. ${ }^{11}$

No caso brasileiro, a consagração de uma nova fase e um novo papel para o Código Civil ocorre a partir da Constituição Federal de 1988 que introduziu em seu art. $1^{\circ}$, inciso III, o princípio da dignidade da pessoa humana como um dos fundamentos da República e o "alicerce de nossa ordem jurídica democrática”"12, alcançando todos os ramos do direito.

O Código Civil então deixa de ser considerado a "Constituição do direito privado" ${ }^{3}$, perdendo a sua centralidade por uma série de fatores, dentre os quais: o fato de que existe a necessidade de tutela cada vez mais específica de sujeitos

\footnotetext{
${ }^{10}$ A Constitucionalização do Direito Civil caracteriza uma mudança de paradigma no direto, pois trata-se de uma necessária interpretação da legislação infraconstitucional sob a ótica Constitucional, bem como o deslocamento normativo de matéria até então afeta apenas ao direito privado para o corpo da Constituição. CANTALI, Fernanda Borghetti. Direitos da personalidade: disponibilidade relativa, autonomia privada e dignidade humana. - Porto Alegre: Ed. Livraria do Advogado, 2009, p. 53.

${ }^{11}$ MORAES, Maria Celina Bodin de. O jovem direito civil constitucional. In: revista eletrônica de direito civil. Ano $1 \mathrm{n}^{\circ}$ 1/2012. Disponível em http://civilistica.com/o-jovem-direito-civilconstitucional. Acessado em 16 de fevereiro de 2014 às 23:00.

${ }^{12}$ MORAES, Maria Celina Bodin de. O jovem direito civil constitucional. In: revista eletrônica de direito civil. Ano $1 \mathrm{n}^{\circ}$ 1/2012. Disponível em http://civilistica.com/o-jovem-direito-civilconstitucional. Acessado em 16 de fevereiro de 2014 às 23:00.

${ }^{13}$ Expressão utilizada por Gustavo Tepedino. TEPEDINO, Gustavo. Temas de direito civil. $3^{\text {a }}$ edição atualizada. - Rio de Janeiro: Renovar, 2004, p. 2.
} 
cada vez mais específicos. Daí a proliferação de leis especiais para tutelar esses sujeitos/pessoas.

A Constituição Federal, ao admitir a dignidade da pessoa humana como fundamento da república, estabelece um mesmo paradigma para todas as relações privadas. O sujeito ainda que tutelado na sua relação especial é, antes de tudo, pessoa e, nesse sentido, deve ser tratado e protegido.

O centro do ordenamento jurídico deixa de ser uma regra generalista de ordem privada - o Código Civil - e passa a ser uma norma fundamental de ordem também fundamental - a Constituição Federal.

O Direito Civil contemporâneo, através de uma leitura à luz da Constituição ampara-se na proteção à pessoa humana, tratando-se de um direito personalista, deixando de lado aquela visão patrimonialista que existia com o Código de 1916.

Neste norte, detecta-se uma nova metodologia aplicada ao Direito Civil, fundada na Constituição, em que devem prevalecer as relações existenciais, ou não patrimoniais, porque deve o ordenamento jurídico inteiro e, em particular, o ordenamento civil, assegurar, prioritariamente, a tutela e proteção à pessoa humana.

Portanto, abre-se uma reflexão sobre o início do reconhecimento da personalidade da pessoa em um Direito Civil contemporâneo, em que se procurará abordar o tema através da visão civil constitucional, por ser a pessoa tutelada antes de tudo.

\section{2}

\section{A dignidade humana como cláusula geral de tutela da personalidade.}

É sabido que o Direito Civil trata de um ramo do direito que tutela a vida cotidiana das pessoas no ciclo vital de sua existência, ou mesmo, desde a concepção e após o seu fim. É um ramo do direito fundamentado no individualismo e no patrimonialismo, mas que a partir da vigência da Constituição Federal de 1988 se rendeu a proteger a pessoa e não mais, prioritariamente, o patrimônio. 
Desde a promulgação da Constituição de 1988 o Direito Civil é objeto de uma grande renovação, em que seus principais institutos, até então fundamentados no individualismo e no patrimônio, passam por um processo de reconstrução.

O professor Gustavo Tepedino, já no ano de 1992, proferindo aula inaugural da Faculdade de Direito da Universidade do Estado do Rio de Janeiro, apenas três anos após a vigência da Constituição da República, afirmava ser “imprescindível e urgente uma releitura do Código Civil e das leis especiais à luz da Constituição”14. Nesse intuito é que os vários institutos contidos na legislação civilista vêm passando por uma constante revisão ${ }^{15}$.

Dentre os vários institutos, o que se entende por pessoa, dada sua importância transdisciplinar e protagonismo civil, reclama atenção especial.

A partir de uma nova concepção da figura de pessoa, procura-se redesenhar alguns conceitos que dependem deste instituto, como, por exemplo, a identidade jurídica do nascituro - ente que já foi concebido no ventre materno, mas que ainda não nasceu - como pessoa ou não.

Neste sentido surge a seguinte questão: Na hipótese da admissão de tutela existencial ao nascituro, cabe o reconhecimento de sua personalidade jurídica a fim de resguardar os direitos da personalidade?

A situação de estar o feto já concebido no ventre materno, mas ainda não nascido, gera muita discussão em nossa doutrina e jurisprudência, existindo enorme controvérsia acerca da natureza jurídica da personalidade deste ente, pois na atualidade há uma série de relações jurídicas nas quais o nascituro pode encontrar-se envolvido, tais como o direito à vida, o direito à filiação, o direito ao dano moral, o direito à integridade física e o direito aos alimentos.

A partir de uma perspectiva constitucionalizada do Direito Civil, o conceito de pessoa e o início do reconhecimento de sua personalidade devem ser revisitados, respeitando o princípio da dignidade da pessoa humana.

Após a Constituição de 1988, em que foi reconhecida a prioridade à pessoa humana e não mais ao patrimônio, o estudo sobre a pessoa se tornou de

\footnotetext{
${ }^{14}$ TEPEDINO, Gustavo. Temas de direito civil. $3^{\mathrm{a}}$ edição atualizada. - Rio de Janeiro: Renovar, 2004, p. 1-2.

${ }^{15}$ Após o início da vigência da Constituição Federal de 1988 vários institutos do Direito Civil passaram e passam por uma releitura através da hermenêutica civil-constitucional, procurando analisá-los com uma finalidade personalista e não mais individualista e patrimonialista, como ocorria até a vigência da Constituição.
} 
grande importância, principalmente porque os atributos relativos aos direitos da personalidade vêm sendo constantemente desafiados ${ }^{16}$.

Assim, é de suma importância a análise do princípio da dignidade da pessoa humana.

Alexandre dos Santos Cunha apresenta o princípio da dignidade da pessoa humana como instituto basilar do direito privado e do direito público, tratando-se da interface entre estes direitos. O seu reconhecimento, como fundamento primeiro da ordem jurídica, carrega a necessidade de requestionar várias figuras do Direito Civil, como: a pessoa, o patrimônio, os bens, dentre outros. ${ }^{17}$

Com efeito, o princípio da dignidade da pessoa humana reconhecido como o fundamento da ordem jurídica, associado a outros objetivos constitucionais ligados aos direitos e garantias fundamentais, caracterizam uma "verdadeira cláusula geral de tutela e promoção da pessoa humana, tomada como valor máximo pelo ordenamento”. ${ }^{18}$

Dessa forma, a intenção é procurar abordar o conceito e o conteúdo da dignidade da pessoa humana no âmbito jurídico, reconhecendo este princípio como sendo uma cláusula geral de proteção e tutela da personalidade.

\subsection{1 \\ Evolução e conteúdo da dignidade da pessoa humana}

Antônio Junqueira de Azevedo afirma que "a utilização da expressão dignidade da pessoa humana no mundo do direito é fato histórico recente”19.

É na filosofia que a dignidade da pessoa humana recebeu os contornos utilizados hoje, como a ideia de que o ser humano tem um lugar no centro do

\footnotetext{
${ }^{16}$ PENNA, Iana Soares de Oliveira. Dignidade da pessoa humana e direito à identidade na redesignação sexual. Orientadora: Caitlin Sampaio Mulholland. Rio de Janeiro - PUC RIO Departamento de Direito, 2010, p. 48.

${ }^{17}$ CUNHA, Alexandre dos Santos. Dignidade de pessoa humana: o conceito fundamental do direito civil, in A reconstrução do direito privado. Org. Judith Martins-Costa, São Paulo: Revista dos Tribunais, 2002, p. 260.

${ }_{18}$ TEPEDINO, Gustavo. A parte geral do novo código civil: estudos na perspectiva civilconstitucional, Rio de Janeiro: Renovar, 2002, p. XXV.

${ }^{19}$ AZEVEDO, Antônio Junqueira de. Caracterização jurídica da dignidade da pessoa humana. Revista USP, São Paulo, nº 53, março/maio 2002, p. 90-101. www.usp.br/revistausp/53/09junqueira.pdf. Acesso em: 11/07/2013.
} 
universo (antropocentrismo), a capacidade de autodeterminação do indivíduo e o valor intrínseco reconhecido a cada pessoa ${ }^{20}$.

O conceito filosófico de dignidade humana começou a ser construído na antiguidade, chegando aos contornos utilizados nos dias atuais através das obras de Immanuel Kant, mas somente após a segunda guerra mundial a expressão ganhou conotação internacional e começou a fazer parte das Constituições em todo o mundo, isto em consequência das atrocidades cometidas nos campos de concentração, explicando, em parte, a posição central que a dignidade humana assume nas constituições criadas após a segunda grande guerra ${ }^{21}$.

Já o conceito jurídico da dignidade humana começou a ser modelado depois da segunda grande guerra mundial, em consequência de uma enorme mudança no pensamento jurídico contemporâneo.

Isso é particularmente verdadeiro nas decisões envolvendo casos difíceis, em que não há soluções claras e acabadas no direito positivo. Esses casos envolvem lacunas, princípios conflitantes, desacordos morais ou ambiguidades. Nesse novo ambiente pós-positivista, ${ }^{22}$ no qual a constituição e os princípios constitucionais, expressos ou implícitos, desempenham uma função central, os juízes e as cortes frequentemente necessitam recorrer à moralidade política com a finalidade de aplicar os princípios corretamente. Isso tudo favoreceu a ascensão da dignidade humana. $^{23}$

Isso vem a se coadunar com a afirmação de Hanna Arendt, de que após o término da segunda guerra mundial é que os termos dignidade e dignificação ganharam destaque. Até culminar a primeira e a segunda grande guerras os homens motivados pela revolução industrial instrumentalizaram o mundo criando

20 BARROSO, Luís Roberto. A dignidade da pessoa humana no direito constitucional contemporâneo: a construção de um conceito jurídico à luz da jurisprudência mundial; tradução Humberto Laport de Mello. - $1^{\text {a }}$ reimpressão. - Belo Horizonte: Fórum, 2013, p. 61.

${ }^{21}$ HABERMAS, Jurgen. O conceito de dignidade humana e a utopia realista dos direitos humanos. Trad. Eduardo Mendonça e Letícia de Campos Velho Martel. Do original, enviado pelo autor a convite do Conselho Editorial da RDE: Das Konzept der Menschenwürde und die realistische Utopie der Menschenrechte (2010, korrigierte Fassung), p. 03.

${ }^{22}$ Luis Roberto Barroso afirma que "De certo modo, o pós-positivismo é uma terceira via entre o positivismo e a tradição do direito natural. O pensamento pós-positivista não ignora a importância das exigências do direito por clareza, certeza e objetividade, mas também não o concebe como sendo desconectado da filosofia moral e política. O pós-positivismo rejeita o postulado positivista de separação entre direito, moral e política”. BARROSO, Luís Roberto. A dignidade da pessoa humana no direito constitucional contemporâneo: a construção de um conceito jurídico à luz da jurisprudência mundial; tradução Humberto Laport de Mello. - $1^{a}$ reimpressão. - Belo Horizonte: Fórum, 2013, p. 63.

${ }^{23}$ BARROSO, Luís Roberto. A dignidade da pessoa humana no direito constitucional contemporâneo: a construção de um conceito jurídico à luz da jurisprudência mundial; tradução Humberto Laport de Mello. - $1^{\text {a }}$ reimpressão. - Belo Horizonte: Fórum, 2013, p. 62-63. 
objetos artificiais, transformando a natureza e deixando de lado as capacidades humanas ${ }^{24}$.

Como consequência das brutalidades cometidas no período de guerra, os seres humanos reconheceram sua capacidade de amar, agir e de se comunicar com os outros, propiciando uma qualificação substancial a todo ser humano, "qual seja, a dignidade inerente ao gênero humano". ${ }^{25}$

Percebe-se que a expressão dignidade da pessoa humana atinge uma dimensão interna, que é inviolável por tratar-se do valor intrínseco, subjetivo de cada pessoa, e outra externa, que pode sofrer violações por tratar dos direitos e deveres, de cada pessoa. A primeira dimensão é por si mesma inviolável, já que o valor intrínseco do indivíduo não é perdido em nenhuma circunstância; a segunda pode sofrer ofensas e violações. ${ }^{26}$

Nesta esteira, a dignidade da pessoa humana trata-se de qualidade inseparável a qualquer pessoa, conforme afirma Ingo Wolfgang Sarlet:

\begin{abstract}
Todavia, justamente pelo fato de que a dignidade vem sendo considerada (pelo menos para muitos e mesmo que não exclusivamente) qualidade intrínseca e indissociável de todo e qualquer ser humano e certos de que a destruição de um implicaria a destruição do outro, é que o respeito e a proteção da dignidade da pessoa (de cada uma e de todas as pessoas) constituem-se (ou, ao menos, assim o deveriam) em meta permanente da humanidade, do Estado e do Direito ${ }^{27}$.
\end{abstract}

Assim, o grande problema a enfrentar neste capítulo é o de distinguir quais são as qualidades intrínsecas à pessoa humana, procurando responder a seguinte questão: "mas em que consiste a dignidade humana, expressão reconhecidamente vaga, fluida, indeterminada?”28

\footnotetext{
${ }^{24}$ ARENDT apud BORGES, Janice Silveira. Direito Civil: Atualidades III - princípios jurídicos no direito privado. Coordenadores: César Fiuza, Maria de Fátima Freire de Sá, Bruno Torquato de Oliveira Naves. Belo Horizonte: Del Rey, 2009, p. 89.

${ }^{25}$ ARENDT apud BORGES, Janice Silveira. Direito Civil: Atualidades III - princípios jurídicos no direito privado. Coordenadores: César Fiuza, Maria de Fátima Freire de Sá, Bruno Torquato de Oliveira Naves. Belo Horizonte: Del Rey, 2009, p. 90.

${ }^{26}$ BARROSO, Luís Roberto. A dignidade da pessoa humana no direito constitucional contemporâneo: a construção de um conceito jurídico à luz da jurisprudência mundial; tradução Humberto Laport de Mello. - 1 ${ }^{\text {a }}$ reimpressão. - Belo Horizonte: Fórum, 2013, p. 62.

${ }^{27}$ SARLET, Ingo Wolfgang. Dignidade da pessoa humana e direitos fundamentais na Constituição Federal de 1988. 9. Ed. ver. Atual. 2. Tir. - Porto Alegre: Livraria do Advogado Editora, 2012, p. 31.

${ }^{28}$ MORAES, Maria Celina Bodin de. Na medida da pessoa humana: estudos de direito civil. - Rio de Janeiro: Renovar, 2010, p. 75.
} 
A palavra dignidade tem sua definição etimológica na palavra dignus que vem do latim e tem como significado: "aquele que merece estima e honra, aquele que é importante"29.

De acordo com Maria Celina Bodin de Moraes, a primeira vez que se concebeu a ideia de dignidade ao ser humano individualmente foi ainda no cristianismo, em que a dignidade da pessoa humana fundamentou-se através de dois aspectos:

Foi o cristianismo que, pela primeira vez, concebeu a idéia de uma dignidade pessoal, atribuída a cada indivíduo. O desenvolvimento do pensamento cristão sobre a dignidade humana deu-se sob um duplo fundamento: o homem é um ser originado por Deus para ser o centro da criação; como ser amado por Deus, foi salvo de sua natureza originária através da noção de liberdade de escolha, que o torna capaz de tomar decisões contra o seu desejo natural ${ }^{30}$.

Nesse período, através do pensamento de São Tomás de Aquino ${ }^{31}$, identificou-se a dignidade como implícita ao ser humano, devendo o homem não olhar apenas em direção a Deus, mas olhar para si enquanto pessoa ${ }^{32}$.

Conforme afirmado por Ingo Sarlet, vários teóricos modernos conceituaram a expressão dignidade da pessoa humana, como Samuel Pufendorf, John Locke, Thomas Hobbes e Hugo Grócio, mas foram as ideias de Immanuel Kant que trouxeram forte influência na identificação do conteúdo e conceito de pessoa humana ${ }^{33}$, isto através de seu imperativo categórico, conforme afirmado por Iana Penna na passagem abaixo:

Com o imperativo categórico, Kant anunciou que as pessoas têm dignidade (Wurden) e as coisas têm preço (preis) e que o ser humano jamais pode ser usado como instrumento, sendo um fim em si e jamais um meio de realização de interesse de terceiros. Dessa maneira, a dignidade representa um valor moral, de interesse de todos e que está sempre acima do preço, sendo esse um valor a ser buscado por todos ${ }^{34}$.

\footnotetext{
${ }^{29}$ Ibid., p. 77.

${ }^{30}$ Ibid., p. 77.

${ }^{31}$ Tomás de Aquino foi um padre, filósofo e teólogo que estudou o cristianismo através da visão de Aristóteles.

${ }^{32}$ Ibid., p. 78.

33 SARLET, Ingo Wolfgang. Dignidade da pessoa humana e direitos fundamentais na Constituição Federal de 1988. 9. Ed. ver. Atual. 2. Tir. - Porto Alegre: Livraria do Advogado Editora, 2012, p. 33-49.

${ }^{34}$ PENNA, Iana Soares de Oliveira. Dignidade da pessoa humana e direito à identidade na redesignação sexual. Orientadora: Caitlin Sampaio Mulholland. Rio de Janeiro - PUC RIO Departamento de Direito, 2010, p. 67. Immanuel Kant criou em seu livro Fundamentação da metafísica dos costumes o seguinte imperativo categórico: “... têm, contudo, se são seres irracionais, apenas um valor relativo como meios e por isso se chamam coisas, ao passo que os
} 
Através de Kant a ideia de dignidade se torna inerente a uma autonomia ética da pessoa, na qual o autor abandona as ideias cristãs, produzidas por Tomás de Aquino, e constrói sua visão a partir da racionalidade do ser humano (autonomia da vontade), como fundamento da dignidade da natureza humana.

Assim, para Kant os seres racionais sempre que praticam alguma ação, seja dirigindo a ele mesmo ou a outras pessoas, devem sempre considerar como elemento fim o próprio ser humano.

Para Kant:

O Homem, e, duma maneira geral, todo o ser racional, existe como fim em si mesmo, não simplesmente como meio para o uso arbitrário desta ou daquela vontade. Pelo contrário, em todas as suas ações, tanto nas que se dirigem a outros seres racionais, ele tem sempre de ser considerado simultaneamente como um fim. Portanto, o valor de todos os objetos que possamos adquirir pelas nossas ações é sempre condicional ${ }^{35}$.

Para Ingo Sarlet a conceituação de dignidade da pessoa humana apresentada por Immanuel Kant é a mais utilizada até os dias de hoje por maior parte da doutrina brasileira e estrangeira, mas acrescenta que a concepção adotada por Kant, que sustenta ser a dignidade atributo exclusivamente do ser humano, pode sofrer severas críticas por tratar-se de um antropocentrismo excessivo ${ }^{36}$.

Antônio Junqueira de Azevedo, ao discorrer sobre o princípio da dignidade da pessoa humana apresenta duas concepções diversas da pessoa humana que procuram dar suporte à ideia de dignidade, quais sejam: concepção insular e a concepção própria de uma nova ética ${ }^{37}$.

Junqueira de Azevedo afirma que a concepção insular (fundamentada nas ideias de Immanuel Kant), dominante nos dias atuais, é “fundada no homem como

seres racionais se chamam pessoas, porque a sua natureza os distingue já como fins em si mesmos, quer dizer, como algo que não pode ser empregado como simples meio, e que, por conseguinte, limita nessa medida todo o arbítrio”. KANT, Immanuel. Fundamentação da metafísica dos costumes, p. 68.

${ }^{35}$ KANT apud SARLET, Ingo Wolfgang. Dignidade da pessoa humana e direitos fundamentais na Constituição Federal de 1988. 9. Ed. ver. Atual. 2. Tir. - Porto Alegre: Livraria do Advogado Editora, 2012, p. 40.

36 SARLET, Ingo Wolfgang. Dignidade da pessoa humana e direitos fundamentais na Constituição Federal de 1988. 9. Ed. ver. Atual. 2. Tir. - Porto Alegre: Livraria do Advogado Editora, 2012, p. 42.

37 AZEVEDO, Antônio Junqueira de. Caracterização jurídica da dignidade da pessoa humana. Revista USP, São Paulo, $n^{0}$ 53, março/maio 2002, p. 91. www.usp.br/revistausp/53/09junqueira.pdf. Acesso em: 11/07/2013. 
razão e vontade, segundo uns, como autoconsciência, segundo outros”38, mas que se tornou insuficiente para conceituar a dignidade da pessoa humana, pois, a natureza e a pessoa não se encontram, estando em níveis diferentes.

Por sua vez, a concepção própria de uma nova ética, diferentemente da concepção insular, reconhece o ser humano como um ser integrado à natureza, não sendo apenas este possuidor de autoconsciência. Junqueira de Azevedo afirma que outros seres vivos, como os animais, também são detentores da autoconsciência, tratando-se de uma qualidade inerente ao ser vivo e não apenas ao homem.

Junqueira de Azevedo afirma ainda “que na visão ontológica da concepção insular apenas o ser humano é racional, por isso diferente dos demais seres, estando acima de qualquer outra espécie de ser vivo, diferente dos demais seres, encontrando-se as pessoas e a natureza em planos diferentes, sendo "respectivamente sujeito e objeto". 39

Já a visão na concepção própria de uma nova ética, o ser humano é parte integrante da natureza e não é o único ser dotado de racionalidade ou de autoconsciência ${ }^{40}$.

Antônio Junqueira de Azevedo apresenta duas ideias que afirma tornar a concepção insular insuficiente para conceituar a dignidade humana, que são: o desconhecimento da natureza, inclusive a do homem, e seu caráter subjetivista (fechado), tendo apenas o homem como ser dotado de autoconsciência ${ }^{41}$.

A partir da crítica sobre a concepção insular, Junqueira afirma que "é preciso, pois, aprofundar o conceito de dignidade da pessoa humana" ${ }^{\text {, }}$, uma vez que, a conceituação predominante até os dias atuais pode não mais estar protegendo a pessoa, gerando muitas vezes questões como a da eutanásia, do aborto, da manipulação de embriões, dentre outros.

A tese apresentada pelo jurista tenta por em xeque a afirmativa de que apenas os seres humanos são dotados de razão e vontade, em que apenas os homens têm a capacidade de pensar e querer alguma coisa.

\footnotetext{
${ }^{38}$ Ibid., p. 91.

${ }^{39}$ Ibid. p. 92.

${ }^{40}$ Ibid., p. 92.

${ }^{41}$ Ibid., p. 92.

${ }^{42}$ Ibid., p. 93.
} 
Nota-se que não existe apenas uma tese que procura definir a dignidade, por este motivo não se pode fixar apenas na teoria apresentada por Kant e sim procurar identificar um novo sentido para o termo.

Jurgen Habermas apresenta uma diferença entre a dignidade da pessoa humana e a dignidade da vida humana, em que a primeira expressão consiste na individualidade histórica da vida de uma pessoa, ou seja, refere-se à construção da pessoa em meio a sociedade, sua interação com o mundo e a relação entre pessoas. Já a expressão dignidade da vida humana refere-se ao cuidado e respeito que todos, enquanto pessoa, devem ter com a sua vida e com a vida do outro ${ }^{43}$.

Dessa forma, mesmo reconhecendo o princípio da dignidade da pessoa aos seres vivos, em geral, e não apenas aos seres humanos, é na dignidade do ser humano que se deve focar, pois é o ser humano o centro da sociedade. E mesmo que seja reconhecida "uma dignidade para além da vida humana, tal reconhecimento não, obrigatoriamente, conflita [...] com a noção de dignidade própria e diferenciada - não necessariamente superior e muito menos excludente de outras dignidades - da pessoa humana” ${ }^{44}$.

Apesar da dificuldade em reconhecer a dignidade apenas aos seres humanos, ou, a estes e aos demais seres vivos que detêm autoconsciência, esta deve ser entendida como o reconhecimento do outro e de si mesmo.

Reconhecendo e aprofundando o estudo da dignidade da pessoa com fulcro na pessoa humana, surge a seguinte indagação: em que momento da existência da pessoa é reconhecido o princípio da dignidade?

Para a maior parte da doutrina pátria a resposta a tal pergunta não é possível, pois não se chega a um consenso, mas para Ingo Wolfgang Sarlet através da "lição de G. Dürig, Der Grundsatz der Menschenwürde...”45, a dignidade é centrada sobre a autonomia e a autoconsciência da pessoa humana (fundamento de Kant), que através de uma autonomia abstrata autodetermina sua conduta, independente de ser pessoa em concreto. Neste sentido, Sarlet sustenta que

\footnotetext{
${ }^{43}$ HABERMAS, Jurgen. O futuro da natureza humana. Trad. Karina Jannini. São Paulo: Martins Fontes, 2004, p. 41-53.

${ }^{44}$ SARLET, Ingo Wolfgang. Dignidade da pessoa humana e direitos fundamentais na Constituição Federal de 1988. 9. Ed. ver. Atual. 2. Tir. - Porto Alegre: Livraria do Advogado Editora, 2012, p. 43.

45 SARLET, Ingo Wolfgang. Dignidade da pessoa humana e direitos fundamentais na Constituição Federal de 1988. 9. Ed. ver. Atual. 2. Tir. - Porto Alegre: Livraria do Advogado Editora, 2012, p. 56.
} 
qualquer ser humano é possuidor de dignidade, até mesmo os absolutamente ${ }^{46}$ incapazes e os nascituros. ${ }^{47}$

O momento do reconhecimento da dignidade da pessoa humana é o marco para o início do reconhecimento dos direitos da personalidade, uma vez que a dignidade é apresentada como cláusula geral da personalidade. ${ }^{48}$

Após apresentar um pouco da evolução da dignidade da pessoa humana e seu conteúdo, fundamentados na teoria de Immanuel Kant, fica claro tratar-se de um conceito que se encontra em constante construção, e que está sempre presente na filosofia e no direito, ocupando um lugar central nestas áreas. Há ainda um consenso de que a dignidade da pessoa humana perfaz o valor fundamental às democracias constitucionais espalhadas pelo mundo. É na dignidade humana que as democracias se apoiam e se constituem. ${ }^{49}$

\subsection{2 Conceito jurídico da dignidade humana}

A partir da construção do conteúdo da dignidade humana, nota-se que para apresentar uma reflexão jurídica da expressão é necessário recorrer à sua fonte político-filosófica.

\footnotetext{
${ }^{46}$ A capacidade de agir é a regra. No entanto, diversos fatos podem impedi-la ou limitá-la. Nas pessoas naturais o que impede ou limita a capacidade de fato é a idade e a sanidade; nas pessoas jurídicas, são as irregularidades formais. Quanto à idade das pessoas naturais o ordenamento jurídico estabelece dois momentos da existência como essenciais, que é aos 16 anos e aos 18 anos. Até os 16 anos, entende-se que a pessoa não tem o necessário discernimento para a prática dos atos civis, por isso são absolutamente incapazes. Dos 16 aos 18, entende-se que as pessoas estão relativamente aptas ao exercício, dependendo de assistência dos seus representantes. Já aos 18 anos, entende-se que as pessoas estão aptas ao exercício de sua capacidade. Quanto à sanidade, o Código Civil estabelece os artigos $3^{\circ}$ e $4^{\circ}$, sendo que no art $3^{\circ}$ tem-se casos de incapacidade absoluta e no $4^{\circ}$, capacidade relativa. Os absolutamente incapazes estão impedidos de praticar atos jurídicos, embora tenham capacidade de direito. O direito os afasta da prática dos atos jurídicos por acreditar que não têm o necessário discernimento, mas garante validade aos atos usuais, como compra de gêneros alimentícios, jornais, revistas. AMARAL, Francisco. Direito Civil: Introdução. $7^{\text {a }}$ ed. rev., atual. e aum., Rio de Janeiro: Renovar, 2008, p. 231.

47 SARLET, Ingo Wolfgang. Dignidade da pessoa humana e direitos fundamentais na Constituição Federal de 1988. 9. Ed. ver. Atual. 2. Tir. - Porto Alegre: Livraria do Advogado Editora, 2012, p. 56.

${ }^{48}$ Os direitos da personalidade através da hermenêutica civil constitucional são direitos atribuídos por meio da cláusula geral de direitos da pessoa humana. Gustavo Tepedino afirma que "com efeito, a escolha da dignidade da pessoa humana como fundamento da República, [...], configura uma verdadeira cláusula geral de tutela e promoção da pessoa humana, tomada como valor máximo pelo ordenamento". TEPEDINO, Gustavo. Temas de direito civil. $3^{\mathrm{a}}$ edição atualizada. Rio de Janeiro: Renovar, 2004, p. 50.

${ }^{49}$ MORAES, Maria Celina Bodin de. Na medida da pessoa humana: estudos de direito civil. - Rio de Janeiro: Renovar, 2010, p. 83.
} 
A dignidade da pessoa humana, mesmo após longos estudos acerca de seu conteúdo e significação, continua ocupando "lugar central no pensamento filosófico, político e jurídico” ${ }^{50}$, fazendo parte da essência da pessoa humana que é titular de direitos reconhecidos e que devem ser respeitados por si mesmo, pelo seu semelhante e pelo Estado. ${ }^{51}$

Assim, busca-se neste trabalho não apenas um conceito político-filosófico à expressão, mas um conceito normativo jurídico para que este seja reconhecido como uma cláusula geral dos direitos da personalidade.

Ao longo dos anos a jurisprudência e a doutrina, em geral, trataram de estabelecer algumas definições genéricas da dignidade da pessoa humana.

O princípio da dignidade da pessoa humana, assim como outros princípios jurídicos, por tratar-se de uma categoria aberta axiologicamente ${ }^{52}$, com ideias abertas e vagas, que não consegue uma significação exata para o termo, necessita constantemente construir-se.

Essa afirmativa não deve gerar a renúncia e, muito menos, um abandono do significado jurídico do termo, mas por tratar-se de um conceito de difícil concretização, não se deve procurar apenas defini-lo em situações concretas, e sim procurar legitimá-lo para que sua aplicação não se torne arbitrária. ${ }^{53}$

Dessa forma, Ingo Wolfgang Sarlet pretendendo fundamentar o referido princípio não apenas no âmbito filosófico, mas também no âmbito jurídico, descreve que:

A dignidade, como qualidade intrínseca da pessoa humana, é irrenunciável e inalienável, constituindo elemento que qualifica o ser humano como tal e dele não pode ser destacado, de tal sorte que não se pode cogitar na possibilidade de determinada pessoa ser titular de uma pretensão a que lhe seja concedida a dignidade. Assim, compreendida como qualidade integrante e irrenunciável da própria condição humana, a dignidade pode (e deve) ser reconhecida, respeitada, promovida e protegida, não podendo, contudo, (no sentido ora empregado) ser criada, concedida ou retirada (embora possa ser violada), já que reconhecida e atribuída a cada ser humano como algo que lhe é inerente. ${ }^{54}$

50 SARLET, Ingo Wolfgang. Dignidade da pessoa humana e direitos fundamentais na Constituição Federal de 1988. 9. Ed. ver. Atual. 2. Tir. - Porto Alegre: Livraria do Advogado Editora, 2012, p. 48.

${ }^{51}$ Ibid.

${ }^{52}$ Entende-se categoria axiológica aberta como o princípio da dignidade da pessoa humana sendo um princípio ou um valor de significado aberto.

${ }^{53}$ Ibid., p. 52.

${ }^{54}$ Ibid., p. 52-53. 
Apesar de tentar apresentar o conceito jurídico de dignidade humana, é claro o entendimento de que "a dignidade não existe apenas onde é reconhecida

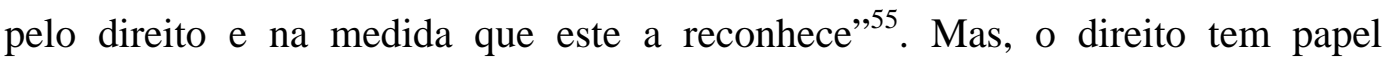
fundamental na construção do significado de dignidade da pessoa humana.

Neste contexto, a dignidade não deve ser reconhecida apenas no momento em que é violada e protegida pelo direito, pois esta é inerente a qualquer pessoa, a partir do momento que há o reconhecimento de que um determinado ente é pessoa. Ou seja, todas as pessoas, enquanto pessoas, são detentoras de dignidade (seja homossexual, negro, criminoso, incapaz etc), conforme posicionamento predominante na doutrina e jurisprudência.

Por outro lado, há quem aponte para o fato de que a dignidade da pessoa não deve ser considerada, pelo menos não exclusivamente, como algo inerente à natureza humana (no sentido de uma qualidade inata pura e simplesmente), à medida que a dignidade possui também um sentido cultural e prestacional do Estado $^{56}$ através da situação concreta da conduta estatal e do comportamento de cada pessoa humana. ${ }^{57}$

Neste contexto, Ingo Sarlet apresenta o princípio da dignidade da pessoa humana como princípio detentor de duas dimensões:

\begin{abstract}
Manifesta-se enquanto, simultaneamente, expressão da autonomia da pessoa humana (vinculada à idéia de autodeterminação no que diz com as decisões essenciais a respeito da própria existência), bem como da necessidade de sua proteção (assistência) por parte da comunidade e do Estado, especialmente quando fragilizada ou até mesmo - e principalmente - quando ausente a capacidade de autodeterminação. ${ }^{58}$
\end{abstract}

\footnotetext{
${ }^{55}$ Ibid., p. 53.

${ }^{56}$ A concepção cultural da dignidade é teoria sendo fruto do trabalho de diversas gerações e da humanidade em seu todo, razão pela qual as dimensões natural e cultural da dignidade da pessoa se complementam e interagem mutuamente, refutando-se a tese de que a dimensão ontológica da dignidade possa ser equiparada a uma dimensão por assim dizer biológica. Como tarefa (prestação) imposta ao Estado, a dignidade da pessoa reclama que este guie as suas ações tanto no sentido de preservar a dignidade existente, quanto objetivando a promoção da dignidade, especialmente criando condições que possibilitem o pleno exercício e fruição da dignidade, sendo,portanto, dependente (a dignidade) da ordem comunitária, já que é de se perquirir até que ponto é possível ao indivíduo realizar, ele próprio, parcial ou totalmente, suas necessidades existenciais básicas ou se necessita, para tanto, do concurso do Estado ou da comunidade. Este é um posicionamento que recorre à circunstância de que a noção de dignidade da pessoa humana não seja considerada apenas como um apelo ético, torna-se necessário para determinar seu significado e conteúdo que ocorra uma situação concreta que necessite da conduta do Estado e do comportamento de cada pessoa. SARLET, Ingo Wolfgang. Dignidade da pessoa humana $e$ direitos fundamentais na Constituição Federal de 1988. 9. Ed. ver. Atual. 2. Tir. - Porto Alegre: Livraria do Advogado Editora, 2012, p. 57-58.

${ }^{57}$ Ibid., p. 57-58.

${ }^{58}$ Ibid., p. 61.
} 
Para Sarlet o princípio da dignidade da pessoa humana, passa a ser enxergado sob duas perspectivas: subjetiva e objetiva. De acordo com a visão subjetiva, a dignidade da pessoa humana é entendida como valor inerente à pessoa, e segundo a visão objetiva a dignidade da pessoa humana é qualidade de toda e qualquer pessoa humana que o faz merecedor de uma vida digna e do respeito por parte do Estado e da sociedade.

Neste norte, detecta-se que o princípio da dignidade da pessoa humana é aplicado não apenas no campo do direito público, mas também no campo do direito privado, ou seja, nas relações particulares. Com isso, enxerga-se que a ideia de dignidade da pessoa humana traz consigo, a um só tempo, uma eficácia negativa e positiva ${ }^{59}$, pois é aplicada na esfera pública e na esfera privada.

Conforme visto, não se trata de tarefa fácil conceituar o princípio da dignidade da pessoa humana, capaz de abranger todas as circunstâncias de cunho filosófico, político e jurídico. Apesar disso, é necessário construir um conteúdo mínimo para defini-lo.

Com base no que foi exposto até o momento, deve-se buscar uma definição que alcance a dignidade como valor intrínseco das pessoas. Com isso, Maria Celina Bodin de Moraes apresenta quatro postulados como substrato material para definir a dignidade da pessoa humana.

O substrato material da dignidade, deste modo entendida, pode ser desdobrado em quatro postulados: i) o sujeito moral (ético) reconhece a existência dos outros como sujeitos iguais a ele; ii) merecedores do mesmo respeito à integridade psicofísica de que é titular; iii) é dotado de vontade livre, de autodeterminação; iv) é parte do grupo social, em relação ao qual tem a garantia de não vir a ser marginalizado. ${ }^{60}$

O princípio da dignidade da pessoa humana para Maria Celina Bodin de Moraes é um 'megaprincípio', do qual desdobram os princípios da igualdade, da integridade psicofísica, da liberdade e da solidariedade para darem o fundamento material a este.

\footnotetext{
${ }^{59}$ No caso da eficácia positiva da dignidade da pessoa humana, esta deve ser garantida, efetivada tanto no direito público como no privado, como ocorre no caso das Ações afirmativas (proteção de pessoas deficientes, inserção do negro no mercado de trabalho etc), já a eficácia negativa serve como limite da atuação do Estado e do Particular, não podendo o Estado e nem o particular exercer um direito com a violação da dignidade de uma pessoa.

${ }^{60}$ MORAES, Maria Celina Bodin de. Na medida da pessoa humana: estudos de direito civil. - Rio de Janeiro: Renovar, 2010, p. 85.
} 
Para Maria Celina quando ocorrem conflitos em situações subjetivas que geram um embate entre princípios de mesmo grau hierárquico, deve ser buscada, no princípio da dignidade da pessoa humana, a solução para este conflito, conforme descreve a autora na passagem a seguir:

Esta decomposição serve, ainda, para demonstrar que, embora possa haver conflitos entre duas ou mais situações jurídicas subjetivas - cada uma delas amparada por um desses princípios, logo, conflito entre princípios de igual importância hierárquica -, o fiel da balança, a medida de ponderação, o objetivo a ser alcançado, já está determinado, a priori, em favor do conceito da dignidade humana. Somente os corolários, ou sub-princípios, em relação ao maior deles, podem ser relativizados, ponderados, estimados. A dignidade, do mesmo modo como ocorre com a justiça, vem à tona no caso concreto, quando e se bem feita aquela ponderação. ${ }^{61}$

Assim, o princípio da dignidade da pessoa humana está condicionado primeiramente à análise e aplicação ou não dos mencionados princípios, ou seja, em um caso concreto, deve-se analisar inicialmente a aplicabilidade de outro princípio constitucional, tratando o caso de agressão à dignidade da pessoa humana e não tendo como solucionar com fundamento em outro princípio, aplicase o da dignidade.

Dessa forma, o princípio que primeiro fundamenta a dignidade da pessoa humana é o da igualdade, que reconhece direitos iguais a todas as pessoas.

O princípio da igualdade adota duas formas: a igualdade formal e a substancial. Na primeira espécie todas as pessoas são iguais perante a lei, mas verificou-se que esta espécie era insuficiente e adotou a igualdade substancial, em que as pessoas devem ser tratadas quando desiguais com desigualdade, ou seja, quando as pessoas são iguais devem ser tratadas com igualdade, mas quando são desiguais devem ser tratadas em conformidade com sua desigualdade.

É assim que Pietro Perlingieri apresenta o princípio da igualdade:

Afirma-se, comumente, que o art. 3 Const. Enuncia no $\S 1$ a igualdade formal e no $\S 2$ aquela substancial; a primeira seria expressão de uma revolução praticamente realizada, a segunda, ao contrário, de uma revolução "prometida". Pela primeira, os cidadãos têm "igual dignidade social e são iguais perante a lei, sem distinção de sexo, de raça, de língua, de religião, de opiniões políticas, de condições pessoais e sociais”; pela segunda, é "tarefa da República remover os obstáculos de ordem econômica e social que, limitando de fato a liberdade e a igualdade dos cidadãos, impedem o pleno desenvolvimento da pessoa humana e a

61 Ibid. 
efetiva participação de todos os trabalhadores na organização política, econômica e social do país”. ${ }^{62}$

A igualdade formal e a substancial são consideradas unitariamente não separando uma da outra, sendo consideradas uma o complemento da outra.

Mas, segundo Maria Celina, nos dias atuais o debate concernente ao princípio da igualdade está focado no direito à diferença, em que ao invés de reconhecer uma identidade comum a todas as pessoas, deve-se buscar na diferença das pessoas o princípio da igualdade. ${ }^{63}$

O princípio da integridade psicofísica é tido como fundamento do princípio da dignidade da pessoa humana por resguardar os direitos à integridade física e psicológica da pessoa, como os direitos à honra, ao corpo, à imagem, à própria vida digna e várias outras espécies que através da evolução biotecnológica surgem a todo o momento em nossa sociedade.

Já o princípio da liberdade era reconhecidamente como fundamento da dignidade da pessoa humana por versar sobre a manifestação livre da vontade humana para realização de seus interesses. Tratava-se de princípio absoluto, em que a pessoa através da autonomia privada era detentora de um amplo poder.

Nos dias atuais o princípio da liberdade ainda garante o exercício da manifestação livre da vontade nas relações privadas, podendo qualquer pessoa praticar seus atos sem a necessidade de interferência do Estado. Mas, essa liberdade passa por uma grande repaginação, devendo as pessoas cooperarem entre si respeitando o princípio da solidariedade.

A solidariedade é fundamentada na vida em sociedade. A, partir do momento que as pessoas dependem umas das outras para viverem em um meio social, estas devem cooperar entre si, exercendo seus direitos em um contexto social e não mais individual como era.

Neste norte, detecta-se que a partir do princípio da dignidade da pessoa humana, fundamentado nos princípios da igualdade, da integridade psicofísica, da liberdade e da solidariedade surge uma cláusula geral de tutela da pessoa que é a base de sustentação dos direitos da personalidade.

\footnotetext{
${ }^{62}$ PERLINGIERI, Pietro. Perfis do direito civil. Tradução de: Maria Cristina de Cicco. $2^{\mathrm{a}}$ ed. Rio de Janeiro: Renovar, 2002, p. 44.

${ }^{63}$ MORAES, Maria Celina Bodin de. Na medida da pessoa humana: estudos de direito civil. - Rio de Janeiro: Renovar, 2010, p. 88.
} 
Os princípios da igualdade, da integridade psicofísica, da liberdade e da solidariedade são fundamentos do princípio da dignidade da pessoa humana, pois, quando há o reconhecimento das outras pessoas como iguais, o fundamento encontra-se no princípio da igualdade; quando as pessoas que são consideradas iguais são detentoras de respeito a sua integridade física e moral, reconhece o princípio da integridade psicofísica; estando as pessoas reconhecidamente livres para realizar seus atos, deve-se garantir o princípio da liberdade, e por fim, estando as pessoas integradas em sociedade, é necessário o atendimento ao princípio da solidariedade. ${ }^{64}$

Portanto, o princípio da dignidade da pessoa humana é a cláusula geral que permite a tutela de situações jurídicas existenciais de forma geral e especificamente dos direitos da personalidade.

\section{3 Pessoa, Personalidade e os Direitos da Personalidade no Direito Brasileiro.}

Após apresentar o princípio da dignidade da pessoa como cláusula geral dos direitos da personalidade, torna-se necessário uma análise da pessoa, da personalidade e dos direitos da personalidade para que, posteriormente, possa-se discutir se o nascituro é detentor de personalidade ou não.

\subsection{1 Direitos da Personalidade no Direito Brasileiro}

Os Direitos da Personalidade são uma categoria de construção recente no mundo do direito. Seu fundamento ganhou corpo a partir da metade do século XIX e compreende os direitos inerentes à pessoa humana. ${ }^{65}$

No Direito Romano a figura dos direitos da personalidade existiam, mas não nos moldes de hoje, naquela época apenas eram contempladas as ações contra a injúria (chamadas de actio injuriarum), criada com a finalidade de punir qualquer ofensa contra as pessoas. ${ }^{66}$

\footnotetext{
${ }^{64}$ Ibid.

${ }^{65}$ TEPEDINO, Gustavo. Temas de direito civil. $3^{\mathrm{a}}$ edição atualizada. - Rio de Janeiro: Renovar, 2004, p. 24.

${ }^{66}$ Ibid., p. 24.
} 
Apesar de não ter relevância para o trabalho, observa-se que a preocupação com a pessoa humana surge propriamente com as declarações de direitos humanos conforme afirmado por vasta doutrina, mas deve-se entender que os direitos humanos surgem para proteger as pessoas da ingerência do Estado, não dando ênfase ao direito privado. Já os direitos da personalidade são analisados sob o mesmo ângulo dos direitos humanos, ou seja, resguardando os direitos inerentes à pessoa, mas entre as relações privadas. ${ }^{67}$

A análise dos direitos da personalidade é de extrema importância para nossa sociedade, uma vez que tais direitos referem-se aos chamados direitos essenciais da pessoa e que garantem o desenvolvimento pleno do ser humano.

Para Adriano De Cupis,

[...] existem certos direitos sem os quais a personalidade restaria uma susceptibilidade completamente irrealizada, privada de todo o valor concreto: direitos sem os quais todos os outros direitos subjectivos perderiam todo o interesse para o indivíduo - o que equivale a dizer que, se eles não existissem, a pessoa não existiria como tal. ${ }^{68}$

O desenvolvimento dos direitos da personalidade desde os primórdios se mostrou bastante conturbado, isto, principalmente, em meados dos séculos XVIII e XIX, devido às características das ditaduras totalitárias, do Estado Liberal e de uma certa dificuldade dos civilistas de compreender o instituto. ${ }^{69}$

Maria Celina Bodin de Moraes afirma que, com o grande progresso científico e tecnológico, principalmente no campo da medicina, com o amplo acesso aos meios de comunicação de massa e a crescente regulamentação jurídica, desafia-se uma nova compreensão aos direitos da personalidade, pois as consequências desses grandes avanços são aparentemente inevitáveis, imprevisíveis e incontroláveis. $^{70}$

Adriano De Cupis define os direitos da personalidade como "uma susceptibilidade de ser titular de direitos e obrigações jurídicas” ${ }^{, 71}$ e trata estes direitos como essenciais a toda pessoa humana, afirma ainda que na falta dos

\footnotetext{
${ }^{67}$ Ibid., p. 33.

${ }^{68}$ DE CUPIS, Adriano. Os direitos da personalidade. Campinas: Romana Jurídica, 2004, p. 17.

${ }^{69}$ Ibid., p. 48-49.

${ }^{70}$ MORAES, Maria Celina Bodin de. Na medida da pessoa humana: estudos de direito civil. - Rio de Janeiro: Renovar, 2010, p. 122-123.

${ }^{71}$ DE CUPIS, Adriano. Os direitos da personalidade. Campinas: Romana Jurídica, 2004, p. 13.
} 
direitos da personalidade os direitos subjetivos não produziriam efeito e as pessoas não existiriam como tal. ${ }^{72}$

Nas palavras de Orlando Gomes os direitos da personalidade, “compreendem-se direitos considerados essenciais à pessoa humana, que a doutrina moderna preconiza e disciplina, a fim de resguardar a sua dignidade”. ${ }^{73}$

Para Gomes, nos dias atuais não deve mais discutir sobre a existência ou não dos direitos da personalidade, pois estes direitos já foram reconhecidos através do poder legislativo. $^{74}$

Durante muito tempo discutiu-se acerca da existência dos direitos da personalidade através das teorias negativistas, segundo Gustavo Tepedino, "afirmava-se em síntese estreita, que a personalidade, identificando-se com a titularidade de direitos, não poderia, ao mesmo tempo, ser considerada como objeto deles" ${ }^{75}$.

Segundo os defensores da teoria negativista, os direitos da personalidade não eram reconhecidos, pois esbarravam na "impossibilidade lógica de colocar no posto de objeto da relação jurídica um bem que se confunde com o próprio sujeito, em uma relação de direito subjetivo"76, ou seja, esses afirmavam que havia uma divergência entre os direitos da personalidade e a personalidade.

Os negativistas afirmavam que a personalidade era sinônimo de capacidade, em que todo ser humano é titular de direitos e deveres, não podendo dessa forma o ser humano ser o objeto de direitos.

A grande dificuldade que os negativistas encontravam para reconhecer os direitos da personalidade está no fato daqueles identificarem os direitos da personalidade com a capacidade.

Para solucionar a problemática apresentada pelos negativistas a noção de personalidade deve sofrer um alargamento, reconhecendo a personalidade como um valor inerente à pessoa.

O doutrinador San Tiago Dantas apresenta a solução à negativa dos direitos da personalidade afirmando que:

\footnotetext{
${ }^{72}$ DE CUPIS, Adriano. Os direitos da personalidade. Campinas: Romana Jurídica, 2004, p. 17.

${ }^{73}$ GOMES, Orlando. Introdução ao direito civil. 13 ed. Rio de Janeiro: Forense, 1998, p. 149.

${ }^{74}$ GOMES, Orlando. Introdução ao direito civil. 13 ed. Rio de Janeiro: Forense, 1998, p. 149.

75 TEPEDINO, Gustavo. Temas de direito civil. $3^{\text {a }}$ edição atualizada. - Rio de Janeiro: Renovar, 2004, p. 25.

${ }^{76}$ DONEDA, Danilo. Os direitos da personalidade no novo código civil. In: TEPEDINO, Gustavo (org.). A parte geral do novo código civil: estudos na perspectiva civil-constitucional. 2 ed. Rio de Janeiro: Renovar, 2003, p. 42.
} 
Quer dizer que a palavra personalidade pode ser tomada em duas acepções: numa acepção puramente técnico-jurídica ela é a capacidade de ter direitos e obrigações e é, como muito bem diz Unger, o pressuposto de todos os direitos subjetivos e, numa outra acepção, que se pode chamar acepção natural: é o conjunto dos atributos humanos e não é identificável.

Aquele pressuposto pode perfeitamente ser o objeto das relações jurídicas. ${ }^{77}$

\section{Perlingieri também contrapõe a teoria negativista afirmando que:}

A esta matéria não se pode aplicar o direito subjetivo elaborado sobre a categoria do "ter". Na categoria do "ser" não existe a dualidade entre sujeito e objeto, porque ambos representam o ser, e a titularidade é institucional, orgânica. Onde o objeto de tutela é a pessoa, a perspectiva deve mudar; torna-se necessidade lógica reconhecer, pela especial natureza do interesse protegido, que é justamente a pessoa a constituir ao mesmo tempo o sujeito titular do direito e o ponto de referência objetivo de relação. ${ }^{78}$

Neste norte, detecta-se que a aplicação dos direitos subjetivos aos direitos da personalidade encontraram certa dificuldade, isto porque o instituto do direito subjetivo, conforme afirmação de larga doutrina, foi construído para a categoria do ter, e não para a categoria do ser, ou seja, "para a tutela do patrimônio, cujos bens objetos eram exteriores ao sujeito, refletindo, assim, a ideologia novecentista”. ${ }^{79}$

O tratamento dos direitos da personalidade como direitos subjetivos surgiu como uma segunda objeção ao reconhecimento dos direitos da personalidade. Acontece que, não é em todas as circunstâncias que os direitos da personalidade se enquadram no conceito de direitos subjetivos ${ }^{80}$.

Nesta medida, segundo afirmado por Danilo Doneda, a doutrina atual reconhece a necessidade de uma releitura do conceito de direito subjetivo de

\footnotetext{
${ }^{77}$ DANTAS, San Tiago. Clássicos da literatura jurídica. Programa de direito civil: parte geral. $4^{\mathrm{a}}$ tiragem. Editora Rio: Rio de Janeiro, 1979, p. 192.

${ }^{78}$ PERLINGIERI, Pietro. Perfis do direito civil. Tradução de: Maria Cristina de Cicco. $2^{\mathrm{a}}$ ed. Rio de Janeiro: Renovar, 2002, p. 155.

${ }^{79}$ CANTALI, Fernanda Borghetti. Direitos da personalidade: disponibilidade relativa, autonomia privada e dignidade humana. - Porto Alegre: Ed. Livraria do Advogado, 2009, p. 67.

${ }^{80}$ De acordo com Pietro Perlingieri “contrapõem-se, tradicionalmente, duas definições de direito subjetivo como poder da vontade e direito subjetivo como interesse protegido. A disputa entre os defensores das duas teorias subtende diversas avaliações e diversas ideologias; nela se espalha a diversidade entre as concepções liberalistas e as primeiras tentativas de entender o direito de um ponto de vista teleológico. A definição corrente salda os dois aspectos: o direito subjetivo é, afirma-se usualmente, o poder reconhecido pelo ordenamento a um sujeito para a realização de um interesse próprio do sujeito”. PERLINGIERI, Pietro. Perfis do direito civil. Tradução de: Maria Cristina de Cicco. $2^{\mathrm{a}}$ ed. - Rio de Janeiro: Renovar, 2002, p. 120.
} 
modo a ampliá-lo do modo tradicional ao qual foi criado e, em especial, no que diz respeito à circulação de bens. ${ }^{81}$

Além de uma releitura do conceito de direito subjetivo, a doutrina precisou ampliar também o conceito de bem, passando a vincular os atributos da pessoa humana (corpo físico, imagem, honra, privacidade etc) como objeto das relações jurídicas.

Mas, conforme afirmado por Maria Celina Bodin de Moraes e Pietro Perlingieri, não se pode vincular a personalidade apenas a direitos subjetivos, pois a tutela humana encontra-se em uma pluralidade de situações jurídicas existenciais.

Segundo Maria Celina,

É facilmente constatável que a personalidade humana não se realiza através de um esquema fixo de situação jurídica subjetiva - o direito subjetivo -, mas sim por meio de uma complexidade de situações subjetivas que se podem apresentar ora como poder jurídico, ora como direito potestativo ou como autoridade parental, interesse legítimo, faculdade, estado; enfim, qualquer acontecimento ou circunstância (rectius, situação) juridicamente relevante. ${ }^{82}$

Pietro Perlingieri afirma que:

Afirmada a natureza necessariamente aberta da normativa, é da máxima importância constatar que a pessoa se realiza não através de um único esquema de situação subjetiva, mas com uma complexidade de situações que ora se apresentam como poder jurídico (potestà), ora como interesse legítimo, ora como direito subjetivo, faculdade, poderes. ${ }^{83}$

Nesta esteira, pode-se afirmar que as situações que têm como objeto direitos inerentes à personalidade não estão atreladas apenas a direitos subjetivos, extrapolando estes direitos e ampliando a situações jurídicas existenciais imensuráveis.

\footnotetext{
${ }^{81}$ DONEDA, Danilo. Os direitos da personalidade no novo código civil. In: TEPEDINO, Gustavo (org.). A parte geral do novo código civil: estudos na perspectiva civil-constitucional. 2 ed. Rio de Janeiro: Renovar, 2003, p. 45.

${ }^{82}$ MORAES, Maria Celina Bodin de. Na medida da pessoa humana: estudos de direito civil. - Rio de Janeiro: Renovar, 2010, p. 126.

${ }^{83}$ PERLINGIERI, Pietro. Perfis do direito civil. Tradução de: Maria Cristina de Cicco. $2^{\mathrm{a}}$ ed. Rio de Janeiro: Renovar, 2002, p. 155.
} 


\subsection{2 \\ Fonte dos direitos da personalidade e o direito geral da personalidade.}

O debate sobre a fonte dos direitos da personalidade é bastante acirrado, tanto na doutrina pátria, como na doutrina estrangeira.

Alguns doutrinadores nacionais defendem que os direitos da personalidade são direitos inatos, tratando-se de direitos naturais, ou seja, direitos que independem de positivação, tendo o jurista apenas a tarefa de reconhecer tais direitos, pois a pessoa é anterior à sociedade. ${ }^{84}$

Carlos Alberto Bittar compartilhando deste entendimento afirma,

Que os direitos da personalidade constituem direitos inatos - como a maioria dos escritores ora atesta - cabendo ao Estado apenas reconhecê-los e sancioná-los em um ou outro plano do direito positivo - em nível constitucional ou em nível de legislação ordinária - e dotando-os de proteção própria, conforme o tipo de relacionamento a que se volte,a saber: contra o arbítrio do poder público ou as incursões de particulares. ${ }^{85}$

Erouths Cortiano Júnior partilhando do mesmo entendimento descreve que “a pessoa humana é um dado pré-jurídico e, por consequência, a proteção de seu núcleo fundamental (sua personalidade e dignidade) desnecessita de expressa previsão legal”. 86

Já Gustavo Tepedino apresenta algumas críticas à concepção jusnaturalista, afirmando que nos dias de hoje tal teoria não tem mais razão de ser, pois traz uma grande dificuldade em definir os direitos inatos. ${ }^{87}$

Entretanto, Fernanda Cantali apresenta críticas à concepção positivista ideológica também, afirmando que esta “implicaria ignorar a dimensão valorativa que este tema envolve. Para que se possa garantir uma efetiva tutela da pessoa

\footnotetext{
${ }^{84}$ CANTALI, Fernanda Borghetti. Direitos da personalidade: disponibilidade relativa, autonomia privada e dignidade humana. - Porto Alegre: Ed. Livraria do Advogado, 2009, p. 73.

${ }^{85}$ BITTAR, Carlos Alberto. Os direitos da personalidade. $-7^{\mathrm{a}}$ ed./atualizada por Eduardo Carlos Bianca Bittar. - Rio de Janeiro: Forense universitária, 2008, p. 7.

86 CORTIANO JUNIOR, Erouths. Alguns apontamentos sobre os chamados direitos da personalidade. In: FACHIN, Luiz (org.), Repensando fundamentos do direito civil contemporâneo. Rio de Janeiro: Renovar, 1999, p. 44.

${ }^{87}$ TEPEDINO, Gustavo. Temas de direito civil. $3^{\text {a }}$ edição atualizada. - Rio de Janeiro: Renovar, 2004, p. 42.
} 
humana é necessário encontrar seu fundamento na norma positiva permeada pelos valores ali também estabelecidos, [...]”. 88

Nesta perspectiva, resta demonstrado que não se deve vincular aos jusnaturalistas e nem aos positivistas ideológicos, devendo "considerar os chamados direitos da personalidade como inatos unicamente pelo fato de nascerem juntamente com a pessoa humana, segundo a disciplina do direito positivo, despidos assim de qualquer conotação jusnaturalista”, 89

E é neste sentido que Tepedino apresenta alguns exemplos que buscam elucidar a difícil tarefa que os jusnaturalistas têm para explicar a aplicação dos direitos da personalidade às situações jurídicas existenciais nos dias atuais de uma forma inata.

\begin{abstract}
A religião muçulmana, com suas penas corporais e as cirurgias através das quais milhares de mulheres africanas são mutiladas, ao nascer, nos dias de hoje; os países cristãos e as concepções ideológicas que adotam a pena de morte; o regime da escravidão em sociedades consideradas civilizadas; a prática de torturas e de linchamento como forma de sanção socialmente reconhecidas em diversos estados brasileiros; tudo isso coloca em crise a simplista tese segundo a qual seria a consciência universal a estabelecer os direitos humanos e os direitos da personalidade, cabendo ao ordenamento jurídico apenas reconhecê-los. ${ }^{90}$
\end{abstract}

Com estes exemplos surge uma interrogação aos defensores da concepção jusnaturalista: onde estão os direitos da personalidade nestas circunstâncias? Dúvida que possivelmente os defensores da concepção jusnaturalista não alcançam uma resposta contundente, o que revela uma destruição desta tese.

Embora os exemplos apresentados por Gustavo Tepedino desqualifiquem a tese jusnaturalista dos direitos da personalidade, não há como qualificar um positivismo radical ou ideológico como fonte que tutela estes direitos, isto porque não “existe um número fechado de hipóteses tuteladas na medida em que é tutelado o valor da pessoa sem limites, o que se dá através do princípio da

\footnotetext{
${ }^{88}$ CANTALI, Fernanda Borghetti. Direitos da personalidade: disponibilidade relativa, autonomia privada e dignidade humana. - Porto Alegre: Ed. Livraria do Advogado, 2009, p. 75. Nesta passagem a autora faz menção à expressão utilizada por Maria Celina Bodin de Moraes em: MORAES, Maria Celina Bodin de. A constitucionalização do direito civil e seus efeitos sobre a responsabilidade civil. In: Souza Neto, Cláudio Pereira de; Sarmento, Daniel (orgs.). A constitucionalização do direito: fundamentos teóricos e aplicações específicas. Rio de Janeiro: Lumen Juris, 2007, p. 234.

${ }^{89}$ TEPEDINO, Gustavo. Temas de direito civil. $3^{\mathrm{a}}$ edição atualizada. - Rio de Janeiro: Renovar, 2004, p. 44.

${ }^{90}$ Ibid., p. 42.
} 
dignidade humana que funciona como verdadeira cláusula geral promocional e protetiva da pessoa humana”. 91

Apesar de a doutrina atual reconhecer a existência de um número em aberto de situações tuteladas à pessoa, por um longo período discutiu-se o assunto.

A discussão travada por um longo período dizia respeito às chamadas teorias atomísticas, nas quais os direitos da personalidade existem através de uma multiplicidade de direitos, e à teoria monista, que defende a existência de um único direito de personalidade.

Os adeptos da teoria atomística, que reconhece uma variedade de direitos da personalidade, ainda apresentam duas subteorias inerentes à multiplicidade de direitos da personalidade. “A primeira, que considera a existência de uma série fechada de direitos, em outras palavras, tipificados ou numerus clausus, e a segunda, que sustenta uma série aberta, ou seja, uma atipicidade de direitos da personalidade". 92

Na doutrina brasileira, vários autores apresentam sua própria classificação inerente aos direitos da personalidade.

Carlos Alberto Bittar distribui os direitos da personalidade em direitos físicos, psíquicos e morais. Os direitos físicos ou inerentes à integridade física compreendem o corpo, os órgãos, os membros e a imagem; já os direitos psíquicos ou inerentes à integridade psíquica da pessoa, compreendem a sua liberdade, intimidade e o sigilo; e os direitos morais compreendem a identidade, a honra e as manifestações do intelecto. ${ }^{93}$

Já Pontes de Miranda apresenta uma classificação diferente da apresentada por Bittar, classificando os direitos da personalidade em os direitos de vida, à saúde (integridade psíquica e física), à liberdade, à honra e a igualdade. ${ }^{94}$

Neste norte, várias críticas foram lançadas às teorias que admitem uma série atípica de direitos da personalidade e a tipificação desses direitos, o que se

\footnotetext{
${ }^{91}$ CANTALI, Fernanda Borghetti. Direitos da personalidade: disponibilidade relativa, autonomia privada e dignidade humana. - Porto Alegre: Ed. Livraria do Advogado, 2009, p. 76. Nesta passagem Fernanda Borghetti Cantali apresenta a idéia de Pietro Perlingieri em: PERLINGIERI, Pietro. Perfis do direito civil. Tradução de: Maria Cristina de Cicco. $2^{\mathrm{a}}$ ed. - Rio de Janeiro: Renovar, 2002, p. 156.

${ }^{92}$ CANTALI, Fernanda Borghetti. Direitos da personalidade: disponibilidade relativa, autonomia privada e dignidade humana. - Porto Alegre: Ed. Livraria do Advogado, 2009, p. 77.

${ }_{93}$ BITTAR, Carlos Alberto. Os direitos da personalidade. - $7^{\mathrm{a}}$ ed./atualizada por Eduardo Carlos Bianca Bittar. - Rio de Janeiro: Forense universitária, 2008, p. 17.

${ }_{94}$ MIRANDA, Pontes de. Tratado de direito privado. $4^{\mathrm{a}}$ ed. - São Paulo: Revista dos Tribunais, 1974, p. 162.
} 
fundamenta pela falta de possibilidade de previsão classificatória que consiga abarcar todos os direitos possíveis inerentes à pessoa humana.

Este fenômeno acabou formando um direito geral de personalidade no sistema jurídico nacional, uma vez que somente uma cláusula geral de promoção e proteção ao ser humano pode tutelar as infinitas situações inerentes à personalidade da pessoa.

Gustavo Tepedino, seguindo o raciocínio, descreve que o direito da personalidade é único, com conteúdo indefinido e diversificado. ${ }^{95}$

Com efeito, não existe a possibilidade de tutelar uma quantidade exata de situações jurídicas existenciais, pois trata-se da tutela de situações inerentes à pessoa humana que apresenta-se sem limites.

Em síntese, o direito geral da personalidade tem o objetivo de tutelar a pessoa em qualquer circunstância, ou seja, os direitos da personalidade são tutelados tanto nas situações tipificadas, como em qualquer outra situação que envolva o ser humano e tenha como prioridade a valorização e a proteção da dignidade da pessoa humana.

Portanto, os direitos da personalidade não podem estar restritos às legislações infraconstitucionais (principalmente à lei civil), uma vez que a Constituição de 1988 protege a pessoa não apenas nas hipóteses previstas em lei, mas em qualquer hipótese em que o objeto é o ser humano.

\subsection{3 Personalidade e Capacidade}

O tema revela-se um dos mais difíceis para identificar sua definição, isto porque a evolução humana e tecnológica expõe a pessoa a todo o momento a situações novas, que exigem uma disciplina do ordenamento jurídico, e como afirma Gustavo Tepedino “a doutrina parece buscar em paradigmas do passado as bases para as soluções das controvérsias que, geradas na sociedade contemporânea, não se ajustam aos modelos nos quais se pretende enquadrálas”. 96

\footnotetext{
${ }^{95}$ TEPEDINO, Gustavo. Temas de direito civil. $3^{\mathrm{a}}$ edição atualizada. - Rio de Janeiro: Renovar, 2004, p. 45.

${ }_{96}$ TEPEDINO, Gustavo. Temas de direito civil. $3^{\mathrm{a}}$ edição atualizada. - Rio de Janeiro: Renovar, 2004, p. 24.
} 
A pessoa “é o ser humano ou entidade com personalidade, aptidão para a titularidade de direitos e deveres" ${ }^{\text {97 }}$, ou seja, toda pessoa ostenta o atributo da personalidade, podendo realizar qualquer ato jurídico que desejar, desde que não esteja proibido.

O vocábulo pessoa é proveniente do latim, persona, que significava máscara na linguagem teatral e era usada para ajustar-se ao rosto e tornar mais forte a voz. Posteriormente, o conceito de persona foi ampliado sendo sinônimo de personagem, ou seja, significando o próprio indivíduo que o ator representava. 98 "E como na vida real os indivíduos desempenham papéis, à semelhança dos atores no palco, o termo passou a significar o ser humano nas suas relações sociais e jurídicas". 99

Mas, não eram todos os seres humanos que eram considerados pessoas, como as mulheres, os escravos etc.

Na antiga Roma, segundo Direito Romano, para ser considerado detentor de personalidade jurídica o homem deveria deter alguns requisitos básicos, sendo livre, não estrangeiro e chefe de família. ${ }^{100}$

Pode-se então afirmar que a pessoa é o sujeito de direitos das relações jurídicas detentor de personalidade jurídica.

Portanto, para uma melhor investigação do que é a personalidade jurídica, é necessário primeiramente apresentar o conceito de pessoa para, posteriormente, definir a personalidade.

Francisco Amaral afirma existir duas concepções de personalidade: a naturalista e a formal ou jurídica. Na concepção naturalista a personalidade é valor inerente à pessoa, sendo todos os seres humanos detentores desta qualidade. Já na concepção formal ou jurídica, a personalidade não é um valor natural ou inerente a todo ser humano, tratando-se de uma atribuição jurídica.

A evolução doutrinária apresenta duas concepções: a naturalista e a formal, ou jurídica. Para a concepção naturalista, todos os indivíduos têm personalidade,

\footnotetext{
${ }^{97}$ AMARAL, Francisco. Direito Civil: Introdução. $7^{\text {a }}$ ed. rev., atual. e aum., Rio de Janeiro: Renovar, 2008, p. 252.

${ }_{98}$ Ibid., p. 253.

${ }^{99}$ Ibid., p. 253.

${ }^{100}$ SILVA, Gabriela Cristina da. A análise da tutela jurídica do nascituro no ordenamento jurídico brasileiro. 2010. Universidade do Vale do Itajaí. Itajaí, 09 de junho de 2010. Disponível em http://siaibib01.univali.br/pdf/Gabriela\%20Cristina\%20da\%20Silva.pdf. .Monografia, $\quad$ p. 25. Acessado em: 25 de janeiro de 2013.
} 
considerada inerente à condição humana como atributo essencial do ser humano, dotado de vontade, liberdade e razão.

Para a concepção formal, própria da ciência jurídica positivista, a personalidade é atribuição ou investidura do direito. Pessoa e ser humano não coincidiriam. Pessoa não seria o ser humano dotado de razão, mas simplesmente o sujeito de direito criado pelo direito objetivo. ${ }^{101}$

Nesta esteira, o ordenamento jurídico pátrio reconhece duas espécies de sujeitos de direito, ou seja, de pessoas, quais são: “as pessoas naturais, isto é, os seres humanos, e as pessoas jurídicas, grupos de pessoas ou de bens a quem o direito atribui titularidade jurídica”102, podendo ambas ser sujeito ativo ou passivo em uma relação jurídica.

Washington de Barros Monteiro ao apresentar o conceito de pessoa descreve que “duas são as espécies de pessoas reconhecidas pela ordem jurídica: a pessoa natural, também chamada de física (o homem, ou melhor, o ente humano, o ser humano) e a pessoa jurídica, igualmente denominada pessoa moral ou pessoa coletiva (agrupamentos humanos visando a fins de interesse comum)" ${ }^{103}$

Dessa forma, as pessoas que são os sujeitos de direito das relações jurídicas estão atreladas à ideia de personalidade, pois, estas são titulares de direitos da personalidade e detentoras de personalidade jurídica.

A personalidade jurídica é a que dá aptidão para que todas as pessoas sejam titulares de direitos e deveres nas relações jurídicas, ou seja, sejam titulares, ativa ou passivamente, em relações jurídicas, mas a personalidade "não se identifica com a capacidade, como costuma defender a doutrina tradicional. Pode existir personalidade sem capacidade [...]”. ${ }^{104}$

Neste diapasão, Ricardo Fiuza liga a pessoa à ideia de personalidade, que exprime a aptidão genérica "para adquirir direitos e contrair obrigações. Sendo a pessoa natural o sujeito das relações jurídicas e a personalidade a possibilidade de ser sujeito, toda pessoa é dotada de personalidade”. ${ }^{105}$

\footnotetext{
101 AMARAL, Francisco. Direito Civil: Introdução. $7^{\mathrm{a}}$ ed. rev., atual. e aum., Rio de Janeiro: Renovar, 2008, p. 253-254.

102 AMARAL, Francisco. Direito Civil: Introdução. $7^{\mathrm{a}}$ ed. rev., atual. e aum., Rio de Janeiro: Renovar, 2008, p. 251.

${ }^{103}$ MONTEIRO, Washington de Barros. Curso de Direito Civil. 37 ed., São Paulo: Saraiva, 2000, $1^{\circ}$ vol., p. 57.

${ }^{104}$ PERLINGIERI, Pietro apud AMARAL, Francisco. Direito Civil: Introdução. $7^{\text {a }}$ ed. rev., atual. e aum., Rio de Janeiro: Renovar, 2008, p. 254.

${ }^{105}$ FIUZA, Ricardo (Coordenador). Novo Código Civil comentado. 6. ed., $4^{\mathrm{a}}$ tiragem. São Paulo: Saraiva, 2008, p. 46.
} 
A legislação civil refere-se ainda à capacidade, instituto proveniente da personalidade jurídica, que é concedido às pessoas através desta, sendo a capacidade um atributo da personalidade.

Vários doutrinadores, como Orlando Gomes e Pontes de Miranda ${ }^{106}$, afirmam que a personalidade é sinônima de capacidade.

Neste sentido, impõe-se, nos dias atuais, uma ampliação deste entendimento, reconhecendo que a capacidade é um atributo da personalidade, mas com ela não se confunde, a doutrina tradicional tem o hábito de descrever que a personalidade se identifica com a capacidade ${ }^{107}$, mas isso não ocorre, conforme afirma o doutrinador Francisco Amaral citando Perlingieri:

A personalidade, mais do que qualificação formal, é um valor jurídico que se reconhece nos indivíduos e, por extensão, em grupos legalmente constituídos, materializando-se na capacidade jurídica ou de direito. A personalidade não se identifica com a capacidade, como costuma defender a doutrina tradicional. Pode existir personalidade sem capacidade, como se verifica com o nascituro, que ainda não tem capacidade, e com os falecidos, que já a perderam. ${ }^{108}$

Assim o artigo $1^{\circ}$ do Código Civil, ao descrever que todas as pessoas são capazes de direitos e deveres na ordem civil, acaba entrosando os conceitos de capacidade e personalidade. Assim, a personalidade é um valor e a capacidade uma medida desse valor, onde a capacidade desdobra-se em capacidade de direito e de fato:

Enquanto a personalidade é um valor, a capacidade é a projeção desse valor que se traduz em um quantum. Capacidade, de capax (que contém), liga-se à idéia de quantidade e, portanto, à possibilidade de medida e de graduação. Pode-se ser mais ou menos capaz, mas não se pode ser mais ou menos pessoa. Compreendese, assim, a existência de direitos da personalidade, não de direitos da capacidade. O ordenamento jurídico reconhece a personalidade e concebe a capacidade, podendo considerar esta um atributo daquela. [...]

A capacidade de direito, como titularidade de direitos e deveres, chamada pela doutrina Francesa de capacidade de gozo, porque é o titular que deles desfruta,

\footnotetext{
${ }^{106}$ Orlando Gomes afirma que "A capacidade de direito confunde-se, hoje, com a personalidade, porque toda pessoa é capaz de ter direitos”. GOMES, Orlando. Introdução ao direito civil. 13 ed. Rio de Janeiro: Forense, 1998, p. 166. Pontes de Miranda também afirma em sua obra que "Personalidade é a capacidade de ser titular de direitos, pretensões, ações e exceções e também de ser sujeito (passivo) de deveres, obrigações, ações e exceções. Capacidade de direito e personalidade são o mesmo". MIRANDA, Pontes de. Tratado de direito privado. $4^{\mathrm{a}}$ ed. - São Paulo: Revista dos Tribunais, 1974, p. 155.

${ }^{107}$ Nesta técnica a doutrina reduz a personalidade à idéia de capacidade de direito culminando na desvalorização jurídica do ser humano, tornando-o um mero instrumento do direito.

${ }^{108}$ AMARAL, Francisco apud PERLINGIERI . Direito Civil: Introdução. $7^{\mathrm{a}}$ ed. rev., atual. e aum., Rio de Janeiro: Renovar, 2008, p. 254.
} 
distingue-se da capacidade de fato, aptidão para o exercício desses direitos e deveres ${ }^{109}$.

Dessa forma, a capacidade de direito ou de gozo é a aptidão para adquirir direitos e deveres na ordem civil, já a aptidão para adquirir direitos e deveres e exercê-los ou utilizá-los, por si mesmo, refere-se à capacidade de fato ou de exercício. Assim, toda pessoa é dotada de capacidade de direito, ou de gozo. Já a capacidade de fato, ou de exercício, não resguarda todas as pessoas, pois está vinculada ao preenchimento de condições materiais de idade e gozo das faculdades físicas e mentais.

Todavia, no Direito Civil brasileiro existem certos entes em abstrato que recebem, em alguns casos, o tratamento dado às pessoas, tais como: o condomínio edilício, o espólio, a herança jacente e vacante, a sociedade irregular ou de fato e a massa falida. Tais entes podem ser titulares de relações jurídicas mesmo sendo considerados despersonalizados ${ }^{110}$.

Nesta esteira, a doutrina tradicional apresenta a utilização do conceito de personalidade jurídica sempre atrelado à ideia de sujeito de direito. Já a doutrina mais atualizada reconhece a existência de entes despersonificados que podem ser sujeitos de direito e que o próprio ordenamento jurídico pátrio lhes confere este status, gerando controvérsia a afirmativa de que a personalidade jurídica está sempre atrelada à ideia de sujeito de direito.

Assim, continuar identificando a personalidade como a titularidade que as pessoas têm para participar de relações jurídicas, caracteriza um direito civil patrimonialista que protege apenas o ter, se esquecendo do ser propriamente, considerando a pessoa humana como um ente desprovido de valor. ${ }^{111}$

O posicionamento de que a personalidade jurídica confunde-se com o conceito de capacidade encontra-se nos dias de hoje fragilizado.

Fernanda Cantali interpretando Pietro Perlingieri em La Personalitá Umana Nell Ordinamento Giurídico afirma que:

\footnotetext{
${ }^{109}$ AMARAL, Francisco. Direito Civil: Introdução. $7^{\mathrm{a}}$ ed. rev., atual. e aum., Rio de Janeiro: Renovar, 2008, p. 254-255.

${ }^{110}$ COELHO, Fábio Ulhoa. Curso de Direito Civil: parte geral, volume 1. - 5a ed. - São Paulo: Saraiva, 2012, p. 154-155.

${ }^{111}$ TEPEDINO, Gustavo. Temas de direito civil. $3^{\text {a }}$ edição atualizada. - Rio de Janeiro: Renovar, 2004, p. 27.
} 
Pietro Perlingieri explicita que tradicionalmente a personalidade é considerada como sendo a possibilidade de ser titular de direito subjetivo, o que significa ter capacidade jurídica. Tal posicionamento se fragiliza pelo simples fato da possibilidade de proteção de direitos da personalidade do nascituro e do falecido, os quais não possuem capacidade jurídica. E não é somente isso, já que personalidade é anterior e muito mais do que a simples capacidade, é valor objetivo, interesse e bem juridicamente tutelado. ${ }^{112}$

Conforme já afirmado, a capacidade é um atributo da personalidade, mas com ela não se confunde.

Gustavo Tepedino apresenta duas teorias inerentes à personalidade:

É que a personalidade, a rigor, pode ser considerada sob dois pontos de vista. Sob o ponto de vista dos atributos da pessoa humana, que a habilita a ser sujeito de direito, tem-se a personalidade como capacidade, indicando a titularidade das relações jurídicas. É o ponto de vista estrutural (atinente à estrutura das situações jurídicas subjetivas), em que a pessoa, tomada em sua subjetividade, identifica-se como o elemento subjetivo das situações jurídicas.

De outro ponto de vista, todavia, tem-se a personalidade como conjunto de características e atributos da pessoa humana, considerada como objeto de proteção por parte do ordenamento jurídico. A pessoa, vista deste ângulo, há de ser tutelada das agressões que afetam a sua personalidade, identificando a doutrina, por isso mesmo, a existência de situações jurídicas subjetivas oponíveis erga omnes. ${ }^{113}$

Numa perspectiva civil-constitucional detecta-se que a personalidade jurídica não mais pode estar ligada à ideia de aptidão para ser sujeito de direitos. Esta deve estar ligada à ideia de dignidade da pessoa humana reconhecendo a toda pessoa uma vida digna.

Assim, percebe-se que o Direito Civil apresenta três características inerentes à pessoa: a personalidade, a capacidade de direito e a capacidade de exercício. Nota-se que toda pessoa é detentora de personalidade e capacidade de direito e nem todas são detentoras da capacidade de exercício, dependendo da idade e da sanidade.

Entretanto, existe um tipo especial de criação jurídica que não é reconhecida como pessoa, não detendo personalidade, mas tendo capacidade. São os entes despersonificados. Será que se pode aplicar a teoria dos entes despersonificados ao nascituro?

\footnotetext{
${ }^{112}$ CANTALI, Fernanda Borghetti. Direitos da personalidade: disponibilidade relativa, autonomia privada e dignidade humana. - Porto Alegre: Ed. Livraria do Advogado, 2009, p. 6364.

${ }^{113}$ TEPEDINO, Gustavo. Temas de direito civil. $3^{\mathrm{a}}$ edição atualizada. - Rio de Janeiro: Renovar, 2004, p. 27.
} 


\section{3 \\ Do Nascituro}

O Nascituro é o ente por nascer, mas já concebido no ventre materno.

O Código Civil de 2002 trata do nascituro em seu art. $2^{\circ}$, onde está descrito que: “A personalidade jurídica da pessoa começa do nascimento com vida; mas a lei põe a salvo, desde a concepção, os direitos do nascituro ${ }^{114 \text { ”. }}$

A redação dada pelo legislador ao dispositivo citado não é de muita clareza e traz várias indagações acerca da natureza jurídica do nascituro, surgindo um grande problema sobre a sua personalidade, ou seja, o nascituro detém personalidade jurídica? Ele é ou não pessoa para fins de atributos de direito?

\section{1}

\section{Conceito de Nascituro}

Segundo afirmado pelo art. $4^{\circ}$ do Código de 1916 e hoje pelo art. $2^{\circ}$ da lei civil, detecta-se que a partir do fenômeno do nascimento com vida convencionouse que todos os seres humanos são dotados de personalidade e que, em decorrência desse fato, o homem se torna pessoa, possibilitando que este seja titular de direitos e deveres na esfera civil.

Portanto, ao interpretar o dispositivo que confere personalidade ao ser humano após o nascimento com vida apresenta dois problemas: “1) o do nascimento com vida; 2) o da condição jurídica do nascituro”. 115

Com relação à necessidade do ser humano ter que nascer vivo para adquirir personalidade, distinguem-se dois elementos: o nascimento, que gera "a separação do filho das vísceras maternais”116, e o elemento vida, que deve ser acompanhado do nascimento, caracterizando-se pela respiração pulmonar que é o primeiro indício de que a criança nasceu com vida, e, consequentemente, a esta primeira respiração o ser humano adquire a personalidade. ${ }^{117}$

\footnotetext{
${ }^{114}$ BRASIL., Código Civil Brasileiro. São Paulo: Saraiva, 2010, p. 23.

${ }^{115}$ Ibid., p. 47.

${ }^{116}$ Ibid., p. 47.

${ }^{117}$ Ibid., p. 47.
} 
O termo nascituro, para Aurélio, provém do latim nascituru, é adjetivo substantivo masculino, cujo significado é “aquele que há de nascer”. 118

Limongi França com apoio na etimologia da palavra (de nasciturus- $a-u m$ ) descreve que nascituro é aquele que há de ou deve nascer, mas diferencia-se da prole eventual $^{119}$, que são aqueles filhos ainda não concebidos, mas que têm legitimidade testamentária. Assim, o conceito jurídico de nascituro para Limongi França é a “pessoa que está por nascer, já concebida no ventre materno”. ${ }^{120}$

Para Silmara Chinelato, o nascituro surge com o fenômeno chamado de nidação, ou seja, quando ocorre a fixação do ovo na parede do útero materno. Com isso, após a fixação do ovo na parede do útero há uma viabilidade num estágio de sobrevida ao nascituro, o que não ocorre com o embrião fertilizado in vitro e que ainda não foi implantado no ventre materno. ${ }^{121}$

Vale salientar que é objeto específico da referida dissertação apenas o nascituro, isto é, o ser já concebido e implantado no ventre materno, já tendo ocorrido a nidação, não sendo objeto de discussão o embrião ${ }^{122}$ ainda não implantado no ventre materno.

Apesar de Maria Cristina Zainaghi apresentar uma conceituação que chama de mais ampla do nascituro ou concebido, analisada dentro de uma visão médica $^{123}$, será discutido no presente trabalho, somente a tutela daquele ente já concebido no ventre da mãe.

\footnotetext{
${ }^{118}$ FERREIRA, Aurélio Buarque de Holanda. Novo dicionário Aurélio da língua portuguesa. - 3. ed. - Curitiba: Positivo, 2004, p. 1.387.

119 A prole eventual, de acordo com o inciso I do artigo 1799 do CC, caracteriza-se pela possibilidade de ter capacidade testamentária passiva: "os filhos, ainda não concebidos, de pessoas indicadas pelo testador, desde que vivas estas ao abrir-se a sucessão".

${ }^{120}$ FRANÇA, Rubens Limongi. Instituições de direito civil. $3^{\mathrm{a}}$ ed. atual. - São Paulo: Saraiva, 1994, p. 48.

${ }^{121}$ ALMEIDA, Silmara J. A. Chinelato e. Tutela civil do nascituro. - São Paulo: Saraiva, 2000, p. 10-11.

${ }^{122}$ Aurélio Buarque de Holanda Ferreira conceitua o embrião como sendo um "organismo rudimentar que se forma no interior da semente; germe, gêmula, plântula”. FERREIRA, Aurélio Buarque de Holanda. Novo dicionário Aurélio da língua portuguesa. - 3. ed. - Curitiba: Positivo, 2004, p. 731.

${ }^{123}$ Maria Cristina Zainaghi afirma que ao analisar o conceito de nascituro cabe uma distinção mais ampla dentro de uma visão da medicina, podendo o nascituro apresentar em sua evolução várias fases, como as que compreendem o Zigoto, Blastócito ou pré-embrião, Embrião e Feto. Zainaghi então prevê simplesmente que existe um ser no útero materno, independentemente de sua fase de desenvolvimento concluindo que o embrião já é nascituro. ZAINAGHI, Maria Cristina. Os meios de defesa dos direitos do nascituro. São Paulo: LTr, 2007, p. 22-25.
} 
Desde o Direito Romano, o tema personalidade jurídica do nascituro se mostra controverso não havendo uma doutrina uniforme sobre a condição daquele que já foi concebido no ventre materno, mas que ainda não nasceu. ${ }^{124}$

Neste sentido afirma Sérgio Abdalla Semião que:

\begin{abstract}
Manifesta-se vacilante, o Direito Romano, quanto ao início da existência da pessoa e da personalidade.

Em algumas vezes era reconhecida personalidade ao nascituro; em outras, se estabelecia uma personalidade condicional, colocando-se a salvo os seus direitos, sob a condição de que nascesse viável e consoante o brocardo: "Nasciturus pro jam nato habetur quoties de ejus commodis agitur”. Em outras ainda, considerava-se a criança não viável como despidade de personalidade e finalmente, às vezes, negava-se personalidade aos monstros ou crianças nascidas sem forma humana. ${ }^{125}$
\end{abstract}

Clóvis Beviláqua descrevendo Windscheid, afirma que “a doutrina romana é a seguinte: o feto no útero materno ainda não é homem, porém, se nasce capaz de direito, a sua existência se computa desde a época da concepção”126. A afirmativa descrita por Beviláqua reconhece ao homem desde o momento da concepção ser sujeito de relações jurídicas, desde que nasça com capacidade.

Porém, segundo afirmado ainda por Beviláqua, a opinião de que a personalidade somente é adquirida após o nascimento com vida, no Direito Romano é dominante ${ }^{127}$, sendo o nascituro apenas parte das vísceras de sua mãe.

Para o Direito Romano, o nascituro além de nascer com vida, deveria ter forma humana. Caso não possuísse forma humana ao ser retirado das vísceras maternas, este era considerado monstrum ${ }^{128}$ e não era reconhecido como pessoa. $^{129}$

\footnotetext{
${ }^{124}$ CHAVES, Benedita Inês Lopes. A tutela jurídica do nascituro. São Paulo: LTr, 2000, p. 21.

${ }^{125}$ SEMIÃO, Sérgio Abdalla. Os direitos do nascituro: aspectos cíveis, criminais e do biodireito. - $2^{\mathrm{a}}$ ed., ver., atual., e ampl. - Belo Horizonte: Del Rey, 2000, p. 46.

${ }^{126}$ BEVILÁQUA, Clóvis. Teoria geral do direito civil. Revista e Atualizada por Caio Mário da Silva Pereira. $2^{\mathrm{a}}$ edição. Rio de Janeiro: Editora Rio, 1980, p. 77.

${ }^{127}$ Ibid.

${ }^{128}$ Benedita Inêz Lopes Chaves afirma que embora não seja encontrada nenhuma definição a respeito nos textos jurídicos, desde os glosadores até o Século XIX, considerava-se "monstrum” o ser que, embora nascido de mulher, apresentasse no todo ou em parte, conformação de animal, o que demonstrava ter sido ele gerado de "coitus cum bestia" (coito com animal). No século passado, porém, a medicina demonstrou que essas relações carnais eram absolutamente estéreis, razão porque esses seres monstruosos não podiam existir e, portanto, todo aquele que nasce do ventre da mulher é ser humano. CHAVES, Benedita Inês Lopes. A tutela jurídica do nascituro. São Paulo: LTr, 2000, p. 22.

${ }^{129}$ SEMIÃO, Sérgio Abdalla. Os direitos do nascituro: aspectos cíveis, criminais e do biodireito. - $2^{\mathrm{a}}$ ed., ver., atual., e ampl. - Belo Horizonte: Del Rey, 2000, p. 47.
} 
Neste diapasão, mesmo admitindo a existência de controvérsia acerca do reconhecimento ou não da personalidade ao nascituro no Direito Romano, certo é que a doutrina predominante não reconhece o nascituro como pessoa.

Sérgio Abdalla Semião afirma que doutrinadores como Teixeira de Freitas, Tomás Nabuco e Clóvis Beviláqua, anteriores à vigência do Código Civil de 1916, reconheciam personalidade ao nascituro. ${ }^{130}$

Clóvis Beviláqua, mesmo afirmando que o nascituro a partir do momento que é concebido torna-se detentor de personalidade jurídica, reconhece que o Código Civil de 1916 adotou a teoria de que a personalidade apenas é adquirida após o nascimento.
Apesar da lógica irrecusável, que sustenta esta opinião, é certo que a opinião contrária é a dominante e por ela se declarou o Código Civil brasileiro, art. 4: a personalidade civil do homem começa do nascimento com vida; mas a lei põe a salvo, desde a concepção, os direito do nascituro. ${ }^{131}$

Detecta-se que o artigo $4^{\circ}$ do Código Civil de 1916 divide-se em duas partes. Na primeira parte o referido artigo adere à corrente que não reconhece a personalidade ao ente já concebido no ventre materno, já a segunda parte do artigo adere à corrente que reconhece a personalidade ao nascituro.

Considerando que apenas são pessoas aqueles que são detentores de personalidade, nota-se que o artigo supramencionado estabelece uma contradição inerente ao início do reconhecimento da personalidade a pessoa.

O Código Civil de 2002 manteve a redação que trata do início do reconhecimento da personalidade em seu artigo $2^{\circ}$, alterando apenas a expressão homem por pessoa, mantendo ainda nos dias atuais a contradição já apontada na Lei Civil de 1916.

A partir da contradição apontada na Lei Civil verifica-se que foram criadas e desenvolvidas várias teorias com a finalidade de definir em que momento se reconhece a pessoa e, consequentemente, a personalidade.

Inicialmente apenas duas teorias eram apresentadas: a natalista e a concepcionista. Destas duas surgiu uma terceira: a teoria da concepção

\footnotetext{
${ }^{130}$ SEMIÃO, Sérgio Abdalla. Os direitos do nascituro: aspectos cíveis, criminais e do biodireito. - $2^{\mathrm{a}}$ ed., ver., atual., e ampl. - Belo Horizonte: Del Rey, 2000, p. 61/62.

${ }^{131}$ BEVILÁQUA, Clóvis. Teoria geral do direito civil. Revista e Atualizada por Caio Mário da Silva Pereira. $2^{\mathrm{a}}$ edição. Rio de Janeiro: Editora Rio, 1980, p. 77.
} 
condicionada. E nos dias atuais há outras teorias que procuram solucionar o problema da personalidade do nascituro.

\subsection{1 \\ Teoria Natalista}

A Teoria Natalista é a adotada pelo Código Civil de 2002, e também pela maior parte dos doutrinadores brasileiros, tendo como adeptos, Silvio de Salvo Venosa, Caio Mário da Silva Pereira, Sérgio Abdalla Semião, Pontes de Miranda, bem como pelo Supremo Tribunal Federal ${ }^{132}$, dentre outros.

A Teoria Natalista defende que a personalidade jurídica da pessoa começa a partir do nascimento com vida, portanto, o nascituro não seria considerado pessoa, uma vez que não possui personalidade jurídica, sendo somente um expectador de direitos. ${ }^{133}$

Assim Caio Mário da Silva Pereira leciona que:

Pelo nosso direito, portanto, antes do nascimento com vida não há personalidade. Mas a Lei cuida, em dadas circunstâncias, de proteger e resguardar os interesses do nascituro. Situações existem, na verdade, em que se reconhece a existência de um direito potencial ao ente concebido, que abrange o infans iam concptus nondum natus: ${ }^{134}[\ldots] .{ }^{135}$

Silvio de Salvo Venosa não pensa diferente ao destacar que:

O fato de o nascituro ter proteção legal, podendo inclusive pedir alimentos, não deve levar a imaginar que tenha ele personalidade tal como a concebe o ordenamento. $\mathrm{Ou}$, sob outros termos, o fato de ter ele capacidade para alguns atos não significa que o ordenamento lhe atribui personalidade. Embora haja quem sufrague o contrário, trata-se de uma situação que somente se aproxima da personalidade, mas com esta não se equipara. A personalidade somente advém do nascimento com vida. ${ }^{136}$

Para os adeptos da Teoria Natalista, o nascituro não passa de parte do corpo da mãe, não tem vida independente, é parte das vísceras maternas, por isso não pode ser considerado pessoa e a sua personalidade jurídica coincide com

\footnotetext{
132 Teoria adotada pelo Supremo Tribunal Federal através da decisão da ADIN no 3510, proposta pelo Procurador Geral da República, tendo por alvo a discussão sobre a suposta inconstitucionalidade do art. $5^{\circ}$ da Lei da Biossegurança (Lei $\left.n^{\circ} 11.105 / 2005\right)$ referente à possibilidade de realização de pesquisas a partir da utilização de células tronco embrionárias.

${ }^{133}$ CHAVES, Benedita Inêz Lopes. A tutela jurídica do nascituro. São Paulo: Ltr, 2000, p. 25.

134 "A criança já concebida, ainda não nascida".

${ }^{135}$ PEREIRA, Caio Mario da Silva. Instituições de direito civil. - 24. Ed. - Rio de Janeiro: Editora Forense, 2011, p. 183.

${ }^{136}$ VENOSA, Silvio de Salvo. Direito Civil. 8 ed. São Paulo: Atlas, 2008, p. 137.
} 
exato momento de seu nascimento. Mas não basta apenas o nascimento, este deve vir acompanhado da vida.

Nesse sentido, Pontes de Miranda dispõe que:

No útero, a criança não é pessoa. Se não nasce viva, nunca adquiriu direitos, nunca foi sujeito de direito, nem pôde ter sido sujeito de direito (= nunca foi pessoa). Todavia, entre a concepção e o nascimento, o ser vivo pode achar-se em situação tal que se tenha de esperar o nascimento para se saber se algum direito, pretensão, ação ou exceção lhe deveria ter tido. Quando o nascimento se consuma, a personalidade começa. Não é preciso que se haja cortado o cordão umbilical; basta que a criança haja terminado de nascer (= sair da mãe) com vida. A viabilidade, isto é, a aptidão a continuar de viver não é de exigir-se. Se a ciência médica responde que nasceu vivo, porém seria impossível viver mais tempo, foi pessoa, no curto trato do tempo em que viveu. ${ }^{137}$

Neste sentido, detecta-se que para os adeptos da teoria Natalista basta o nascituro nascer com vida que este si torna pessoa, ou seja, a partir do momento que o nascituro é retirado do ventre materno e recebe ar em seus pulmões, este se torna pessoa e, portanto, titular de direitos e deveres na ordem jurídica. Mesmo o nascituro nascendo e segundos após seu nascimento, morrendo, para a teoria natalista ele adquiriu personalidade.

San Tiago Dantas, em acordo com tal teoria, assim se manifesta:

\begin{abstract}
A personalidade data do nascimento e não basta o nascer, precisa-se nascer com vida. Nascimento com vida é, pois, o elemento essencial para que se inicie a personalidade.

[...]

De fato, desde o momento em que o homem está concebido, mas ainda no ventre materno, já a ordem jurídica toma conhecimento de sua existência e confere-lhe a sua proteção.

[...]

De maneira que parece que desde o período da sua vida intra-uterina já o homem é sujeito de direitos, já tem uma capacidade, já se iniciou, por conseguinte, a sua personalidade.

Os projetos do Código Civil Brasileiro variaram muito na solução que deviam adotar com relação a esta data inicial da personalidade, mas, no nosso Código Civil, assunto não deixa lugar a dúvidas. - a personalidade data do nascimento. ${ }^{138}$
\end{abstract}

Washington de Barros Monteiro completa,

\footnotetext{
${ }^{137}$ MIRANDA, Pontes de. Tratado de direito privado. $4^{\mathrm{a}}$ ed. - São Paulo: Revista dos Tribunais, 1974, p. 162-163.

${ }^{138}$ DANTAS, San Tiago. Clássicos da literatura jurídica. Programa de direito civi. Parte geral. 4. Tiragem. Rio de Janeiro: Editora Rio, 1979, p. 170.
} 
Para que ocorra o fato do nascimento, ponto de partida da personalidade, preciso será que a criança se separe completamente do ventre materno. Ainda não terá nascido enquanto a este permanecer ligado ao cordão umbilical. Não importa que o parto tenha sido natural, ou haja exigido intervenção cirúrgica. Não importa, outrossim, que tenha sido a termo ou fora do tempo. Também é irrelevante a forma pela qual se deu a concepção, ou a gestação, bastando ter ocorrido o nascimento.

Não basta, contudo, o simples fato do nascimento. É necessário ainda que o recém-nascido haja dados sinais inequívocos de vida, como vagidos e movimentos próprios. Também a respiração, evidenciada pela docimasia hidrostática de Galeno ${ }^{139}$, constitui sinal concludente de que a criança nasceu com vida. ${ }^{140}$

Entretanto, os doutrinadores adeptos a Teoria Natalista, não deixaram o nascituro desamparado de todos os seus direitos antes do nascimento. Como bem ensina Washington de Barros Monteiro “adotou o legislador a primeira solução: a personalidade começa do nascimento com vida; nem por isso, entretanto, são descurados os direitos do nascituro.” 141

Portanto, do ponto de vista da Teoria Natalista, o nascituro não pode ser considerado pessoa e nem possuir personalidade jurídica, tendo em vista que ele é dependente do corpo da mãe, que é responsável pela sua mantença e nutrição até o momento do seu nascimento. O nascituro, portanto, é apenas expectador de direitos, sendo que, ao nascer com vida é que ele passa a ser considerado pessoa diante do ordenamento jurídico passando, então, a ser detentor de direitos.

Os adeptos desta teoria esbarram em várias questões que a torna distante da realidade vivida atualmente, como as novas técnicas de reprodução assistida e da proteção dos direitos do embrião, negando em alguns momentos os próprios direitos fundamentais inerentes ao nascituro, como o direito à vida, ao nome, aos alimentos dentre outros ${ }^{142}$. Mas, vale ressaltar, novamente, que se trata da teoria adotada pelo ordenamento jurídico pátrio.

\footnotetext{
${ }^{139}$ Trata-se de uma medida pericial com a finalidade de verificar se uma criança nasce viva ou morta, neste sentido Washington de Barros Monteiro descreve que essa prova se baseia no princípio de que o feto, depois de haver respirado, tem os pulmões cheios de ar. Assim, imersos em água, eles sobrenadam, o que não sucede com os pulmões que não respiram.

${ }^{140}$ MONTEIRO, Washington de Barros. Curso de direito civil: parte geral. 42. ed. rev. e atual. por Ana Cristina de Barros Monteiro França Pinto. São Paulo: Saraiva, 2010, p. 66.

${ }^{141}$ MONTEIRO, Washington de Barros. Curso de direito civil: parte geral. 42. ed. rev. e atual. por Ana Cristina de Barros Monteiro França Pinto. São Paulo: Saraiva, 2010, p. 67.

${ }^{142}$ TARTUCE, Flávio. A situação jurídica do nascituro: uma página a ser virada no Direito Brasileiro. In: Questões controvertidas do código civil. Parte Geral. Mário Luiz Delgado e Jones Figueiredo Alves (Coords.). São Paulo: Método, 2007, p. 83-104.
} 


\section{1 .2}

\section{Teoria da Concepção}

A Teoria da concepção ou concepcionista sustenta a ideia de que o nascituro é pessoa, estando desde o momento de sua concepção com todos os seus direitos resguardados pelo ordenamento jurídico.

A maioria dos defensores desta corrente utiliza como fundamento os ensinamentos de Teixeira de Freitas no art. $1^{\mathrm{o}}$ do esboço de Código Civil, apresentado por ele em 1865, e partem de uma interpretação literal do art. $2^{\circ}$ do Código Civil de 2002, que prescreve em sua primeira parte que a personalidade jurídica inicia com o nascimento com vida.

A maioria dos autores citados aponta que a origem da teoria está no Esboço de Código Civil elaborado por Teixeira de Freitas, pela previsão constante do art. $1^{\circ}$ da sua Consolidação das Leis Civis "As pessoas consideram-se como nascidas apenas formadas no ventre materno; a Lei lhes conserva seu direito de sucessão ao tempo de nascimento". Assim, ao considerar como nascidas as pessoas concebidas, o Esboço de Teixeira de Freitas, atribui direitos ao nascituro ${ }^{143}$.

Nelson Rosenvald e Cristiano Chaves vão mais além e afirmam que esta teoria encontra-se alicerçada no próprio Código Civil de 2002, trazendo como referências as regras prescritas em vários artigos do diploma civil, conforme passagem descrita abaixo:

Essa teoria está alicerçada, corretamente, no próprio Código Civil Brasileiro, buscando como referência as regras contidas nos arts. 1609, Parágrafo Único (que permite o reconhecimento da filiação do nascituro), 1.779 (versando sobre a possibilidade de nomeação de curador ao nascituro), 542 (autorizando que se faça doação ao nascituro) e 1.798 (reconhecendo a capacidade sucessória do nascituro). Assim, vislumbram que a ordem jurídica, verdadeiramente, reconhece a personalidade jurídica do nascituro, conferindo personalidade concreta e não condicionada ao seu nascimento com vida. ${ }^{144}$

Nesse sentido Francisco Amaral leciona sobre o tema:

Sujeitos titulares dos direitos da personalidade são todos os seres humanos, no ciclo vital de sua existência, isto é, desde a concepção, seja esta natural ou

\footnotetext{
${ }^{143}$ Ibid.

${ }^{144}$ FARIAS, ROSENVALD, Cristiano Chaves de, Nelson. Direito Civil: teoria geral. $9^{\mathrm{a}}$ ed., Rio de Janeiro: Lumen Juris, 2011, p. 283.
} 
assistida (fertilização in vitro ou intratubária), como decorrência da garantia constitucional do direito à vida. ${ }^{145}$

Silmara Chinelato citando Anacleto de Oliveira Faria e André Franco Montoro, afirma que os direitos do nascituro não podem ficar condicionados ao nascimento com vida, devendo esta condição relacionar apenas aos direitos patrimoniais, estando os direitos existenciais garantidos à pessoa mesmo antes do seu nascimento. ${ }^{146}$

A referida autora ainda acrescenta “a personalidade do nascituro não é condicional; apenas certos efeitos de certos direitos dependem do nascimento com vida, notadamente os direitos patrimoniais materiais, como a doação e a herança”. ${ }^{147}$

A seguir, Silmara Chinelato ensina que:

[...] mesmo que ao nascituro fosse reconhecido apenas um status ou um direito, ainda assim seria forçoso reconhecer-lhe a personalidade, porque não há direito ou status sem sujeito, nem há sujeito de direito que tenha completa e integral capacidade jurídica (de direito ou de fato), que se refere sempre a certos e determinados direitos particularmente considerados. ${ }^{148}$

Neste sentido, identifica-se que não há meia personalidade ou personalidade parcial, não se quantifica a personalidade, ou seja, não existe uma pessoa com mais ou menos personalidade, mas sim com mais ou menos capacidade (capacidade de direito ou de fato).

Os defensores desta Teoria afirmam que o fato do nascituro não ser detentor de alguns direitos não lhe retira a personalidade. Mesmo as pessoas já nascidas não são detentoras de todos os direitos e todas as obrigações reconhecidas pelo ordenamento jurídico.

Dessa forma, os concepcionistas analisam a proteção concedida ao nascituro pelo ordenamento jurídico e concluem que ele é titular de inúmeros direitos, devendo ser considerados detentores de personalidade jurídica desde o momento que são concebidos.

Rubens Limongi França afirma que:

\footnotetext{
${ }^{145}$ AMARAL, Francisco. Direito civil: introdução. - 7. Ed. rev., atual. e aum. - Rio de Janeiro: Renovar, 2008, p. 287.

${ }^{146}$ ALMEIDA, Silmara J. A. Chinelato e. Tutela Civil do nascituro.. - São Paulo: Saraiva, 2000, p. 158.

${ }_{147}$ Ibid., p. 169.

${ }^{148}$ Ibid., p. 168.
} 
2) Juridicamente, entram em perplexidade total aqueles que tentam afirmar a impossibilidade de atribuir capacidade ao nascituro "por este não ser pessoa". A legislação de todos os povos civilizados é a primeira a desmenti-lo. Não há nação que se preze (até a China) onde não se reconheça a necessidade de proteger os direitos do nascituro (Código chinês, art. $7^{\circ}$ ). Ora, quem diz direitos afirma capacidade. Quem afirma capacidade reconhece personalidade. ${ }^{149}$

Nesta esteira, os adeptos da Teoria concepcionista arrematam a discussão afirmando que é reconhecido ao nascituro, pelo ordenamento jurídico, inúmeros direitos, devendo ser aquele reconhecido como pessoa, ou seja, detentor de personalidade jurídica.

\subsection{3 \\ Teoria da Concepção Condicionada}

Para esta teoria o nascituro adquire personalidade desde a concepção, porém, está condicionado ao nascimento com vida. Assim, com o nascimento bem sucedido, a personalidade retroagirá ao momento da concepção. Dessa forma Maria Cristina Zainaghi dispõe que "a teoria condicional admite a personalidade retroativa desde a concepção, condicionada, porém, ao nascimento", ${ }^{150}$

Para Washington de Barros Monteiro, defensor desta teoria:

Discute-se se o nascituro é pessoa virtual, cidadão em germe, homem in spem. Seja qual for a conceituação, há para o feto uma expectativa de vida humana, uma pessoa em formação. A lei não pode ignorá-lo e por isso lhe salvaguarda os eventuais direitos.

Mas para que estes se adquiram, preciso é que ocorra o nascimento com vida. Por assim dizer, o nascituro é pessoa condicionada; a aquisição de personalidade acha-se sob a dependência de condição suspensiva, o nascimento com vida. ${ }^{151}$

Neste sentido, Silmara Chinelato descreve em sua obra Tutela Civil do Nascituro, os artigos 221 e 222 do esboço de Código Civil criado por Teixeira de Freitas e levanta a discussão de ser este doutrinador adepto da teoria da concepção condicionada ou não.

\footnotetext{
${ }^{149}$ FRANÇA, Rubens Limongi. Instituições de direito civil. $3^{\mathrm{a}}$ ed. atual. - São Paulo: Saraiva, 1994, p. 50

${ }^{150}$ ZAINAGHI, Maria Cristina. Os meios de defesa dos direitos do nascituro. São Paulo: LTr, 2007, p. 50.

${ }^{151}$ MONTEIRO, Washington de Barros. Curso de Direito Civil: parte geral. 42. ed. rev. e atual. por Ana Cristina de Barros Monteiro França Pinto. São Paulo: Saraiva, 2010, p. 68.
} 
O Esboço de Código Civil de Teixeira de Freitas, no qual se inspirou o Código Civil Argentino, dispõe no art. 221 que "desde a concepção no ventre materno começa a existência visível das pessoas e, antes de seu nascimento, elas podem adquirir direitos, como se já estivessem nascidas”. O art. 222 faz, porém, uma ressalva que nos poderia levar à conclusão de que consagra a teoria da personalidade condicional:

"Esses direitos só ficarão irrevogavelmente adquiridos, se os concebidos nascerem com vida, isto é, se a manifestarem, ainda que por instantes, depois de completamente separados de sua mãe". ${ }^{152}$

Acontece que, o próprio art. 221 do Esboço de Teixeira de Freitas retira qualquer possibilidade dele ser adepto à teoria da concepção condicionada, uma vez que neste artigo o autor defende que o nascituro é considerado pessoa desde o momento de sua concepção.

Chinelato defende ainda que o art. 222 do Esboço de Teixeira de Freitas, ao descrever que os direitos somente serão adquiridos pelos nascituros se estes nascerem com vida, refere-se apenas aos direitos patrimoniais (doação, herança), não atingindo, neste caso, os direitos de cunho meramente existencial. ${ }^{153}$

Sobre a discussão de ser o nascituro uma pessoa virtual, homem in spem, o doutrinador Miguel Maria de Serpa Lopes também é adepto da teoria da concepção condicionada, entendendo que o nascituro não é possuidor de personalidade e que os direitos inerentes ao nascituro são subordinados à condição deste nascer com vida.

Na verdade, consoante o sistema adotado pelo nosso Código Civil, como pelos demais códigos que seguem a rota do Direito Romano, a aquisição de todos os direitos surgidos médio tempore da concepção subordina-se à condição de que o feto venha a ter existência: se tal acontece, dá-se a aquisição; mas, ao contrário, se não houver nascimento com vida, ou por ter ocorrido um aborto ou por se tratar de um natimorto, não há uma perda ou uma transmissão de direitos, como deverá de suceder se ao nascituro fosse reconhecida uma ficta personalidade. ${ }^{154}$

Fabio Ulhoa Coelho acompanhando o mesmo raciocínio dispõe que, “[...] além dos direitos assegurados em razão da sua posterior personificação - isto é, condicionados ao seu nascimento com vida -, também se encontram espalhadas

\footnotetext{
${ }^{152}$ ALMEIDA, Silmara J. A. Chinelato e. Tutela civil do nascituro. - São Paulo: Saraiva, 2000, p. 148-149.

${ }^{153}$ Ibid., p. 151.

${ }^{154}$ LOPES, Miguel Maria de Serpa. Curso de direito civil: introdução, parte geral e teoria dos negócios jurídicos, volume I. - $9^{\mathrm{a}}$ ed. ver. e atual. pelo Prof. José Serpa de Santa Maria - Rio de Janeiro: Freitas Bastos, 2000, p. 289-290.
} 
pelo ordenamento jurídico normas que visam protegê-lo independentemente desta condição”. 155

Portanto, os adeptos dessa teoria colocam os direitos do nascituro em uma posição suspensiva, de modo condicional. Se ele vier a nascer com vida, terá seus direitos garantidos desde a concepção.

Seguindo este mesmo entendimento Fábio Ulhoa Coelho defende ainda que "a condição para que o nascituro seja sujeito de direito, isto é, tenha seus direitos legalmente protegidos, é a de que venha a nascer com vida”. ${ }^{156}$

Mas, assim como a Teoria Natalista, esta teoria carrega vários pontos controversos, como o seu apego a questões patrimoniais, deixando de lado as respostas referentes à pessoa e à personalidade jurídica. ${ }^{157}$

\section{2 \\ Teorias Análogas}

As teorias análogas procuram discutir e solucionar a natureza jurídica de algumas entidades jurídicas, como os entes despersonificados e os animais, a que o ordenamento jurídico brasileiro reconhece como titular de direitos e deveres, mas, assim como o nascituro, levantam o problema do reconhecimento ou não da personalidade jurídica a estes entes.

\subsection{1}

\section{Teoria dos Entes Despersonificados}

Os sujeitos de direito, para Francisco Amaral, são as pessoas naturais e jurídicas - grupos de pessoas ou de bens - que participam das relações jurídicas, sendo titulares de direitos e deveres. ${ }^{158}$

\footnotetext{
${ }^{155}$ COELHO, Fábio Ulhoa. Curso de direito civil: parte geral, volume 1.- 4. Ed. - São Paulo: Saraiva, 2010, p. 161.

${ }^{156}$ COELHO, Fábio Ulhoa. Curso de direito civil: parte geral, volume 1.- 4. Ed. - São Paulo: Saraiva, 2010, p. 161.

${ }^{157}$ TARTUCE, Flávio. A situação jurídica do nascituro: uma página a ser virada no Direito Brasileiro. In: Questões controvertidas do código civil. Parte Geral. Mário Luiz Delgado e Jones Figueiredo Alves (Coords.). São Paulo: Método, 2007, p. 83-104.

${ }_{158}$ AMARAL, Francisco. Direito civil: introdução. - 7. ed. rev., atual. e aum. - Rio de Janeiro: Renovar, 2008, p. 251.
} 
Neste sentido, considera-se pessoa não apenas os entes físicos que nascem com vida, mas também os entes coletivos que são formados por pessoas ou por bens e que são titulares de direitos e deveres na ordem jurídica.

Essa característica, que qualifica as pessoas a participarem de relações jurídicas, se chama personalidade jurídica, e todas as pessoas são detentoras dela.

Para Francisco Amaral:

Pessoa é o ser humano ou entidade com personalidade, aptidão para a titularidade de direitos e deveres.

Titularidade de um direito é a união do sujeito com esse direito. Não há sujeitos sem direitos, como não há direitos sem titular.

É na pessoa que os direitos se localizam, por isso ela é sujeito de direitos ou centro de imputações jurídicas no sentido de que a ela se atribuem posições jurídicas.

[...]. Na linguagem jurídica, pessoa é o ser com personalidade jurídica, aptidão para a titularidade de direitos e deveres. Todo ser humano é pessoa pelo fato de nascerem ou até de ser concebido. Pessoa é o ser humano como sujeito de direitos. $^{159}$

As pessoas naturais são todos os seres humanos nascidos, ou até os já concebidos, e as pessoas jurídicas, um conjunto de pessoas ou bens dotado de personalidade jurídica.

Nota-se que o ordenamento jurídico confere personalidade jurídica aos seres humanos e a certos entes coletivos que são constituídos de capacidade jurídica, conforme afirma Caio Mário da Silva Pereira:

Toda pessoa é dotada de capacidade jurídica, que a habilita a adquirir direitos. Todo ser humano é sujeito da relação jurídica. Mas não é somente a ele que o ordenamento legal reconhece esta faculdade. [...] Mas a complexidade da vida civil e a necessidade da conjugação de esforços de vários indivíduos para a consecução de objetivos comuns ou de interesse social, ao mesmo passo que aconselham e estimulam a sua agregação e polarização de suas atividades, sugerem ao direito equiparar à própria pessoa natural certos agrupamentos de indivíduos e certas destinações patrimoniais e lhes aconselham atribuir personalidade e capacidade de ação aos entes abstratos assim gerados. Surgem, então, as pessoas jurídicas. ${ }^{160}$

\footnotetext{
${ }^{159}$ AMARAL, Francisco. Direito civil: introdução. - 7. ed. rev., atual. e aum. - Rio de Janeiro: Renovar, 2008, p. 251.

${ }^{160}$ PEREIRA, Cáio Mário da Silva. Instituições de direito civil. - 24 ed. - Rio de Janeiro: Forense, 2011, p. 247.
} 
As pessoas jurídicas, assim como os seres humanos, são consideradas sujeitos de direito com personalidade, estando autorizadas a praticar os atos da vida civil.

A princípio o direito civil sustenta que toda pessoa é dotada de capacidade e "onde falta esta capacidade - nascituro, pessoa jurídica ilegalmente constituída , é porque não há personalidade”. 161

Mas, o próprio Direito Civil brasileiro reconhece que, além das pessoas naturais e jurídicas, existem certos entes em abstrato que recebem, em algumas circunstâncias, o tratamento dado às pessoas, como descrevem Nelson Rosenvald e Cristiano Chaves:

\begin{abstract}
Todavia, não se pode olvidar que, determinadas entidades ou grupos não personalizados (isto é, desprovidas de personalidade jurídica, existindo, apenas, pelo prisma fático), como, por exemplo, o condomínio edilício, a sociedade de fato ou a massa falida, podem titularizar diversas relações jurídicas, mesmo não possuindo personalidade[...]. Ou seja, mesmo não dispondo de personalidade jurídica (que não lhes foi reconhecida pelo sistema jurídico), os entes despersonalizados podem ser sujeitos de direitos, titularizando, no polo ativo ou passivo, incontáveis relações jurídicas.
\end{abstract}

Tais entes, segundo César Fiuza, por um longo período receberam diversos nomes, como personalidade anômala ${ }^{162}$, nunca chegando, a doutrina, a um consenso de sua natureza jurídica. Em alguns casos eram tratados como pessoas, em outros como quase pessoa, mas na realidade os entes que não possuem personalidade (despersonificados ou despersonalizados) são tratados pelo ordenamento jurídico como se fossem pessoas. ${ }^{163}$

Contudo, os entes despersonificados trazem diversas características das pessoas, mas não é reconhecida personalidade a elas, uma vez que faltam requisitos considerados imprescindíveis à personificação.

Neste sentido manifesta-se Silvio de Salvo Venosa:

Há determinadas entidades com muitas das características das pessoas jurídicas, mas que não chegam a ganhar sua personalidade. Faltam-lhes requisitos imprescindíveis à personificação, embora, na maioria das vezes, tenham representação processual, isto é, podem agir no processo, ativa e passivamente,

\footnotetext{
${ }^{161}$ PEREIRA, Cáio Mário da Silva. Instituições de direito civil. - 24 ed. - Rio de Janeiro: Forense, 2011, p. 222.

${ }^{162}$ Expressão utilizada por Silvio de Salvo Venosa.

${ }^{163}$ FIÚZA, César. Direito civil: curso completo. 8. ed., rev., atual. e ampl. - Belo Horizonte: Del Rey, 2004, p. 150.
} 
como ser transeunte entre a pessoa jurídica e um corpo apenas materializado, um simples agrupamento, sem que haja a affectio societatis, porque são formados independentemente da vontade de seus membros ou por ato jurídico que vincule um corpo de bens. ${ }^{164}$

Segundo Orlando Gomes, “a ordem jurídica não as eleva à categoria de pessoas, por lhes faltarem pressupostos necessários à subjetivação”. 165

Embora em diversas circunstâncias os entes despersonificados figurem como sujeitos de direitos (como o direito de ser representados ativa e passivamente em processo judicial), eles não foram inseridos pela doutrina pátria no rol das pessoas, surgindo grandes indagações referentes à natureza jurídica destes entes: seriam eles dotados de personalidade ou não? Existe a possibilidade de reconhecer um ser como sujeito de direitos sem lhe ser conferido personalidade? É possível dissociar sujeito de direito de personalidade? Qual a natureza jurídica dos entes despersonificados?

Para César Fiuza, os entes despersonificados são “organismos sem personalidade, que recebem o tratamento de pessoa”166, tendo como única diferença das pessoas o reconhecimento de organismos tratados como entidades.

Já para Silvio de Salvo Venosa, os entes despersonificados carregam “muitas das características das pessoas jurídicas, mas que não chegam a ganhar sua personalidade" 167 , faltando-lhes diversos requisitos para serem detentores de personalidade, existindo uma capacidade, ou personalidade diminuída ou restrita a esses entes.

Vale salientar que, o art. 12 do Código de Processo Civil conferiu o direito dos entes despersonificados (condomínio ${ }^{168}$, massa falida ${ }^{169}$, espólio ${ }^{170}$, herança vacante e jacente ${ }^{171}$ e sociedades irregulares ${ }^{172}$ ) figurarem como partes nas

\footnotetext{
${ }^{164}$ VENOSA, Silvio de Salvo. Direito civil: parte geral. - 9. ed. - São Paulo: Atlas, 2009, p. 239.

${ }^{165}$ GOMES, Orlando. Introdução ao direito civil. Rio de Janeiro: Forense, 1998, p. 197.

${ }^{166}$ FIÚZA, César. Direito civil: curso completo. 8. ed., rev., atual. e ampl. - Belo Horizonte: Del Rey, 2004, p. 150.

${ }^{167}$ VENOSA, Silvio de Salvo. Direito civil: parte geral. - 9. ed. - São Paulo: Atlas, 2009, p. 239.

168 "Condomínio é uma situação jurídica em que duas ou mais pessoas detêm os mesmos direitos e deveres de dono sobre uma mesma coisa, a um só tempo”. FIÚZA, César. Direito civil: curso completo. 8. ed., rev., atual. e ampl. - Belo Horizonte: Del Rey, 2004, p. 150.

${ }^{169}$ A Massa Falida "é o conjunto de bens formado com a decretação de falência de uma pessoa jurídica”. FIÚZA, César. Direito civil: curso completo. 8. ed., rev., atual. e ampl. - Belo Horizonte: Del Rey, 2004, p. 121.

${ }^{170}$ Espólio é um "conjunto de bens formado com a morte de alguém”. FIÚZA, César. Direito civil: curso completo. 8. ed., rev., atual. e ampl. - Belo Horizonte: Del Rey, 2004, p. 1295.

171 "Falecendo alguém sem deixar testamento nem herdeiro legítimo notoriamente conhecido, os bens da herança, depois de arrecadados, ficarão sob a guarda e administração de um curador, até a
} 
relações processuais, apresentando um enorme problema inerente a estes entes ao ordenamento jurídico, pois os entes que não eram enquadrados no rol de sujeitos de direitos no ordenamento jurídico, com a faculdade de ser parte em uma relação processual, passaram a enquadrar no rol de sujeitos de direitos.

Fábio Ulhoa Coelho, ao discorrer acerca dos sujeitos de direito, apresenta os sujeitos de direito personificados, que são as pessoas naturais e jurídicas (estas desde que estejam com seus atos constitutivos devidamente registrados em órgão competente), e os sujeitos de direito despersonificados, que se dividem em despersonificado humano (nascituro) e despersonificado não humano (espólio, condomínio, massa falida, herança vacante e jacente, sociedades irregulares e outros). ${ }^{173}$

Além do direito de figurarem como parte nas relações processuais, estes entes, em abstrato, são titulares de uma série de outros direitos na esfera jurídica, como ser credor ou devedor em determinada relação ou mesmo realizar diversos outros negócios jurídicos.

Contudo, mesmo sendo inseridos como sujeitos de direitos em relações jurídicas, os entes despersonificados não foram inseridos no rol de pessoas pelo ordenamento jurídico brasileiro.

O que se afere é que o ordenamento jurídico, em consonância com a doutrina e a jurisprudência pátrias, vem imputando aos chamados entes despersonificados, como o espólio, a massa falida, dentre outros, a qualidade de sujeito de direitos, reconhecendo a eles a capacidade jurídica, mesmo sendo desprovidos de personalidade jurídica.

Seguindo o mesmo raciocínio, Fábio Ulhoa Coelho afirma que:

[...], os sujeitos despersonificados podem ser humanos ou não humanos. O homem e a mulher, enquanto se encontram em processo de gestação no útero materno (nascituros), são já sujeitos de direito, embora não sejam ainda pessoas. $\mathrm{O}$ art. $2^{\circ}$ do CC estabelece que "a personalidade civil da pessoa começa do nascimento com vida; mas a lei põe a salvo, desde a concepção, os direitos do nascituro". Isso significa que, antes do nascimento com vida, o homem e a

sua entrega ao sucessor devidamente habilitado ou à declaração de sua vacância”. FIÚZA, César. Direito civil: curso completo. 8. ed., rev., atual. e ampl. - Belo Horizonte: Del Rey, 2004, p. 1198. 172 As Sociedades de Fato ou Irregulares são empresas que possuem ou não estatuto ou contrato social, mas que não foram registrados nos órgãos competentes, conforme definido pela legislação. FIÚZA, César. Direito civil: curso completo. 8. ed., rev., atual. e ampl. - Belo Horizonte: Del Rey, 2004, p. 121.

${ }^{173}$ COELHO, Fábio Ulhoa. Curso de direito civil: parte geral, volume 1.- 4. Ed. - São Paulo: Saraiva, 2010, p. 151-169. 
mulher não têm personalidade, mas, como já titularizaram os direitos postos a salvo pela lei, são sujeitos de direitos. ${ }^{174}$

Eder Marques Azevedo descreve ainda que:

O que se pode aferir sobre essas entidades é que o ordenamento jurídico brasileiro está reconhecendo a elas a capacidade jurídica, mesmo sendo desprovidas de personalidade civil, imputando-lhes a prerrogativa de representação em juízo. É a partir dessa análise que se conclui que a falta de personalidade jurídica não afasta do direito a condição de entidades despersonificadas atuarem como sujeitos de direito, o que, a princípio, já relativiza o pressuposto inicial da existência de personalidade jurídica para a assunção de direitos e obrigações. ${ }^{175}$

\section{Manifesta-se também Daniel Braga Lourenço:}

A aplicação da teoria dos entes despersonificados soluciona com maestria e lucidez a questão do nascituro. De acordo com as límpidas lições do professor Fábio Ulhoa Coelho, 'os sujeitos despersonificados podem ser humanos ou não humanos', de modo que 'antes do nascimento com vida, o homem e a mulher não têm personalidade, mas, como já titularizaram os direitos postos a salvo pela lei, são sujeitos de direito'. Assim, de acordo com melhor entendimento, o nascituro é um sujeito de direito despersonificado humano. ${ }^{176}$

Portanto, segundo os defensores da teoria dos entes despersonificados o nascituro trata-se de um ente não personificado, pois o art. $2^{\circ}$ do Código Civil de 2002 prescreve o início da personalidade após o nascimento com vida, mas põe a salvo, desde a concepção, os direitos do nascituro. Com a ressalva constante no art. $2^{\circ}$ do Código Civil, o nascituro é titular de direitos personalíssimos (direito à vida, direito a alimentos, direito a indenização por dano moral, direito a ter nome dentre outros), mas não o torna detentor de personalidade jurídica, resguardando a lei desde a concepção seus direitos.

Assim, a teoria dos entes despersonificados reconhece ser o nascituro um sujeito de direitos sem personalidade jurídica, este reconhecimento é o mesmo alcançado nos dias atuais aos animais como restará demonstrado nos tópicos a seguir.

${ }^{174}$ COELHO, Fábio Ulhoa. Curso de direito civil: parte geral, volume 1.- 4. Ed. - São Paulo: Saraiva, 2010, p. 159.

${ }^{175}$ AZEVEDO, Eder Marques. Da Desconstrução do Homo Sapiens à Consolidação dos Animais Não-humanos como sujeitos de direito: Uma questão de personalidade?. No prelo da Revista de Direito da Universidade do Estado do Rio de Janeiro - UERJ.

${ }^{176}$ LOURENÇO, Daniel Braga. Direito dos Animais: fundamentação e novas perspectivas. Porto Alegre: Sérgio Antônio Fabris, 2008, p. 505-506. 


\title{
3.2 .2
}

\section{Natureza Jurídica dos Animais}

Francisco Amaral, ao referir-se sobre os animais, afirma que estes ”não são sujeitos, também não são coisas”177, mas o ordenamento jurídico em sua esfera constitucional e infraconstitucional protege-os, com a finalidade de garantir-lhes a função ecológica, evitar sua extinção e defendê-los dos seres humanos.

Nos dias atuais, a doutrina discute o reconhecimento dos animais como sujeitos de direitos, ou mesmo a existência de uma personalidade jurídica sui generis a estes seres, ou seja, a doutrina caminha a passos largos para deixar de classificar os animais como sinônimos de bens, para dar-lhes uma aptidão de titularizar direitos e deveres.

\section{Conforme afirma Eder Azevedo interpretando as palavras de Zygmunt} Bauman:

\begin{abstract}
A vida em sociedade demanda uma relação de dependência e interação entre os indivíduos. No entanto, tal como denuncia Zygmunt Bauman, os padrões sociais, na atualidade, têm passado por transformações sucessivas, gerando embaraços políticos, éticos e culturais, o que revela uma fluidez de valores e de visões do mundo. É a chamada modernidade líquida ${ }^{178}$, cujos reflexos propiciam o surgimento de diferentes visões ambientais que analisam a quem o Direito Ambiental serve, ou seja, olhares distintos do homem e do direito em face do meio ambiente. Dentre elas estão as visões antropocêntrica ${ }^{179}$ e a biocêntrica (ou ecocêntrica ${ }^{180}$ ).
\end{abstract}

\footnotetext{
${ }^{177}$ AMARAL, Francisco. Direito civil: introdução. - 7. ed. rev., atual. e aum. - Rio de Janeiro: Renovar, 2008, p. 251-252.

178 "O que está acontecendo hoje é, por assim dizer, uma redistribuição e a realocação dos "poderes de derretimento" da modernidade. Primeiro, eles afetaram as instituições existentes, as molduras que circunscreviam o domínio das ações-escolhas possíveis, como os estamentos hereditários com sua alocação por atribuição, sem chance de apelação. Configurações, constelações, padrões de dependência e interação, tudo isso foi posto a derreter no cadinho, para ser depois novamente moldado e refeito; essa foi a fase de "quebrar a forma" na história da modernidade inerentemente transgressiva, rompedora de fronteiras e capaz de tudo desmoronar." BAUMAN apud AZEVEDO, Eder Marques. Da Desconstrução do Homo Sapiens à Consolidação dos Animais Não-humanos como sujeitos de direito: Uma questão de personalidade?. No prelo da Revista de Direito da Universidade do Estado do Rio de Janeiro - UERJ.

${ }^{179}$ Visão que vislumbra a pessoa humana como destinatária do Direito Ambiental, subdividida em duas correntes: “a) Antropocêntrica utilitarista: considera a natureza como principal fonte de recurso para atender as necessidades do ser humano; b) Antropocêntrica protecionista: tem a natureza como um bem coletivo essencial que deve ser preservado como garantia de sobrevivência e bem-estar do homem.” SILVA, Romeu Faria Thomé da. Manual de Direito Ambiental. Salvador, Bahia: JusPODIVM, 2011, p. 61.

180 "Já a corrente ecocêntrica (ou biocêntrica), considera o ser humano como mais um integrante do ecossistema, do todo, onde a fauna, a flora e a biodiversidade são merecedores de especial
} 
Em regra, as normas que procuram proteger os animais e a biodiversidade, revelam que os seres humanos estão deixando a posição de centro das preocupações ambientais (visão antropocêntrica), para reconhecer que as diversas formas de vida existentes são igualmente importantes, abrangendo os animais humanos, não humanos, dentre outros.

Carlos Alberto Molinaro comenta o tema apresentando duas conclusões, uma que revela a posição antropocêntrica da relação homem/natureza e a outra que revela uma posição biocêntrica:

A primeira está a se ver, de matiz nitidamente antropocêntrica, [...] uma visão unidimensional e puramente instrumental da natureza que tem vindo a fundamentar dogmaticamente o Estado de Direito Ambiental e que serve à generalidade das decisões jurídicas e econômicas susceptíveis de ter incidência ambiental. A segunda tem um horizonte mais largo e integrador, vê o subproduto da relação natureza/cultura, o ambiente como sujeito, atribuindo-lhe uma dignidade autônoma [...] é uma visão ecocêntrica, pois corresponde a uma consideração valorativa do Homem enquanto parte integrante da Natureza. O princípio antropocêntrico é substituído por um princípio biocêntrico, não no sentido em que o valor Natureza se substituiu ao valor Homem, mas sim no sentido em que o valor radica na existência de uma comunidade biótica em cujo vértice nos encontramos. ${ }^{181}$

Observa-se que a perspectiva biocêntrica reconhece que os seres humanos e os animais têm uma relevância nas relações jurídicas, havendo um enorme equilíbrio nestas relações.

O que se depreende da transição do antropocentrismo para o biocentrismo é que há um complemento deste sobre aquele, pois no biocentrismo se visualiza uma melhor defesa dos animais ao reconhecê-los como sujeitos de direitos. ${ }^{182}$

Luís Paulo Sirvinskas comentando essa transição do antropocentrismo para o biocentrismo reconhece os animais como sujeitos de direitos, salientando a necessidade da construção de uma nova base ética normativa de proteção ao meio ambiente:

proteção e devem ter direitos semelhantes aos dos seres humanos.” SILVA, Romeu Faria Thomé da. Manual de Direito Ambiental. Salvador, Bahia: JusPODIVM, 2011, p. 60.

${ }_{181}$ MOLINARO, Carlos Alberto; MEDEIROS, Fernanda Luiza Fontoura de; SARLET, Ingo Wolfgang; FENSTERSEIFER, Tiago [org.] A dignidade da vida e os direitos fundamentais para além dos humanos: uma discussão necessária. Belo Horizonte: Fórum, 2008, p. 48.

${ }^{182}$ AZEVEDO, Eder Marques. Da Desconstrução do Homo Sapiens à Consolidação dos Animais Não-humanos como sujeitos de direito: Uma questão de personalidade?. No prelo da Revista de Direito da Universidade do Estado do Rio de Janeiro - UERJ. 
Todos os recursos naturais são considerados coisas e apropriáveis sob o ponto de vista econômico, incluindo aí a flora, a fauna e os minérios. Essa apropriação é possível pelo fato de o homem ser o centro das preocupações ambientais antropocentrismo. Há, no entanto, quem entenda que a flora, a fauna e a biodiversidade também são sujeitos de direito, devendo ser protegidos pelo direito - biocentrismo. Todos os seres vivos têm o direito de viver. ${ }^{183}$

Nota-se que o biocentrismo exerce grande influência no direito dos animais, gerando um enorme impulso através de diversas legislações.

A Constituição Federal de 1988 destinou um capítulo inteiro ao meio ambiente, incumbindo o Poder Público e toda a sociedade do dever de proteção aos animais, conforme art. $225{ }^{184}$

Quanto à legislação infraconstitucional, merece destaque a Lei 9.605/98, conhecida como a Lei dos crimes ambientais, que estabelece em seu art. $32^{185}$ a condição da fauna como sujeito passivo em crimes ambientais.

A Lei 9.605/98 prescreve como crime a prática de experiência dolorosa ou cruel em animais vivos, mesmo que a finalidade seja científica ou didática, devendo ser sempre observados procedimentos de forma que não causem dano e nem sofrimento aos animais. A melhor forma de evitar a utilização do animal de forma danosa é buscar formas alternativas de realizar as pesquisas científicas e didáticas.

Recentemente, veio à tona no Brasil o caso do Instituto Royal, um laboratório que realiza testes em animais de remédios usados para o tratamento de doenças como câncer, diabete, hipertensão, epilepsia, dentre outros. Ativistas, no dia 18 (dezoito) de outubro de 2013 (dois mil e treze), invadiram a sede do laboratório, que é localizado em São Roque no interior de São Paulo, em defesa

\footnotetext{
${ }^{183}$ SIRVINSKAS, Luís Paulo. Manual de Direito Ambiental. 5. ed., rev. e atual. São Paulo: Saraiva, 2007, p. 8.

184 “Art. 225. Todos têm direito ao meio ambiente ecologicamente equilibrado, bem de uso comum do povo e essencial à sadia qualidade de vida, impondo-se ao Poder Público e à coletividade o dever de defendê-lo e preservá-lo para as presentes e futuras gerações: [...]”. TOLEDO; WINDT e CÉSPEDES. Vade Mecum. Obra coletiva de autoria da Editora Saraiva com colaboração de Antônio Luiz de Toledo Pinto, Márcia Cristina Vaz dos Santos Windt e Livia Céspedes. 7. ed. atual. e ampl. São Paulo: Saraiva, 2009. P. 69-70.

185 “Art. 32 - Praticar ato de abuso, maus tratos, ferir ou mutilar animais silvestres, domésticos ou domesticados, nativos ou exóticos: Pena - detenção de três meses a um ano, e multa. § $1^{\circ}$ - Incorre nas mesmas penas quem realiza experiência dolorosa ou cruel em animal vivo, ainda que para fins didáticos ou científicos, quando existirem recursos alternativos”. BRASIL. Lei $\boldsymbol{n}^{\circ} \underline{\mathbf{9 . 6 0 5}, \mathbf{d e} \mathbf{1 2} \mathrm{de}}$ fevereiro de 1998. Dispõe sobre as sanções penais e administrativas derivadas de condutas e atividades lesivas ao meio ambiente, e dá outras providências. Disponível em: http://www.planalto.gov.br/ccivil_03/leis/L9605.htm. Acesso em: 06 de janeiro de 2014.
} 
dos animais, com a afirmativa de que os bichos sofriam maus-tratos no local. O grupo composto por cerca de 80 ativistas arrombou o prédio do laboratório e retirou 178 cães da raça beagle e vários coelhos que eram maltratados. ${ }^{186}$

O que se depreende é que o artigo 32 da Lei 9.605/98 ajusta-se perfeitamente à vedação de maus-tratos imposta pelo artigo 225 da Constituição federal, no que tange à utilização de animais em experiências científicas ou didáticas.

O abate de animais para consumo de carne também vem sendo revisto pela perspectiva biocêntrica, pois fala-se hoje no abate humanitário, que consiste na aplicação de método que, supostamente, seja capaz de insensibilizar os animais antes de serem abatidos. Mesmo com a utilização dos métodos humanitários admitidos pela Organização Mundial de Saúde - OMS, não há como se falar na ausência de sofrimento, mas apenas em uma forma de amenizá-lo.

Neste sentido, afirma Eder Azevedo:

Outro enfoque relevante revisto a partir da visão biocêntrica trata-se do abate dos animais para consumo da carne. Apesar de se falar no abate humanitário, realizado com aplicação de métodos supostamente hábeis para insensibilizar o animal antes da sangria (como utilização de gás carbônico, eletrochoque ou pistola de impacto para lesionar o cérebro do animal), não há que se falar na ausência de sofrimento. Existe todo um processo de confinamento durante a engorda, o transporte em caminhões abarrotados, o estresse dos animais no momento que antecede ao abate por visualizar a morte dos outros, além de mais métodos oficiais admitidos pela Organização Mundial da Saúde que, mesmo assim, tornam difícil a crença de possibilidade de insensibilização total. ${ }^{187}$

Diante dos casos expostos Eder Azevedo afirma também que é “fundamental a criação de leis que regulamentem mecanismos rígidos para estas questões, pois reconhecer o direito dos animais de consumo humano é um primeiro passo para se diminuir práticas geradoras de sofrimento em situações como o abate". 188

Neste interim, a doutrina ambientalista apresenta uma dissonância na natureza jurídica dos animais, reconhecendo duas correntes que discutem uma

\footnotetext{
${ }^{186}$ Matéria veiculada em http://g1.globo.com/sao-paulo/sorocaba-jundiai/noticia/2013/11/institutoroyal-relata-nova-invasao-em-sao-roque.html. Acesso em 07 de janeiro de 2014.

${ }^{187}$ AZEVEDO, Eder Marques. Da Desconstrução do Homo Sapiens à Consolidação dos Animais Não-humanos como sujeitos de direito: Uma questão de personalidade?. No prelo da Revista de Direito da Universidade do Estado do Rio de Janeiro - UERJ.

${ }^{188}$ Ibid.
} 
suposta personalidade jurídica a estes seres e a possibilidade dos animais figurarem como sujeitos de direito.

A primeira corrente admite que os animais possuem uma personalidade jurídica sui generis (ou anômala) e os comparam às pessoas absolutamente incapazes ${ }^{189}$, os quais são representados em juízo por seus representantes, no caso dos animais seus proprietários ou o Ministério Público.

Diomar Ackel Filho defende que os animais são possuidores de personalidade jurídica, não podendo ser tratados como bens ou coisas, como se pode observar a seguir:

Eis porque pode-se sustentar que os animais constituem individualidades dotadas de personalidade típica à sua condição. Não são pessoas, na acepção do termo, condição reservada aos humanos. Mas são sujeitos titulares de direitos civis e constitucionais, dotados, pois, de uma personalidade jurídica 'sui generis', típica e própria à sua condição. Claro que a personalidade é atributo da pessoa. E os animais não são pessoas, embora vinculados à mesma biologia. Todavia, como sujeitos de direito são reconhecidos e tutelados, reunindo atributos que permitem colocá-los numa situação jurídica peculiar, que se assemelha aos amentais humanos. ${ }^{190}$

Daniele Tetü Rodrigues compactua com este entendimento ao lecionar que “o direito, enquanto instrumento assegurador da justiça acima de qualquer prioridade, promove o ajustamento do sistema legal à real natureza jurídica dos animais não-humanos, qual seja, de sujeitos de direitos com personalidade jurídica sui generis."191

A segunda corrente defende que os animais são sujeitos de direito, mesmo sendo desprovidos de personalidade jurídica, conforme ocorre com o nascituro, com a massa falida, o espólio, a herança vacante e jacente, o condomínio e as pessoas jurídicas irregulares. Os animais, segundo esta corrente, são considerados sujeitos de direito, ou seja, detentores de vários direitos resguardados por lei, e possuem capacidade postulatória por representação (representados pelo Ministério Público ou por seus proprietários).

189 São "os que a lei considera inaptos ao exercício das atividades da vida civil. São os absolutamente incapazes, que têm direitos, podem adquiri-los, mas não são habilitados a exercêlos. São apartados das atividades civis; não participam direta e pessoalmente de qualquer negócio jurídico”. PEREIRA, Cáio Mário da Silva. Instituições de direito civil. - 24 ed. - Rio de Janeiro: Forense, 2011, p. 229.

${ }^{190}$ ACKEL FILHO, Diomar. Direito dos Animais. São Paulo: Themis, 2001, p. 64-65.

${ }^{191}$ RODRIGUES, Danielle Tetü. O Direito \& os Animais: Uma abordagem Ética, Filosófica e Normativa. 2. ed. Curitiba: Juruá, 2003, 184. 
Daniel Braga Lourenço acompanhando esta corrente afirma que:

\begin{abstract}
A teoria dos entes despersonificados, baseando-se na distinção conceitual entre "pessoa" e "sujeito de direito", conforme se verificou, permite, portanto, que se prescinde da qualificação do ente como "pessoa" para que ele venha a titularizar direitos subjetivos. No que diz respeito aos animais ela poderá ser aplicada para caracterizá-los como autênticos sujeitos de direitos despersonificados nãohumanos, tal qual propõe a criteriosa classificação de Ulhoa Coelho. Como se procurou demonstrar, somente uma visão extremamente dissociada da realidade seria incapaz de realizar que a maior parte das normas de proteção aos animais, incluindo-se em especial, as que vedam os maus-tratos, abusos e crueldades, trata de regras em que o objeto jurídico tutelado é a incolumidade física e psíquica do próprio animal, ou seja, são regras em que o destinatário da norma é aquele beneficiado diretamente pela sua observância é o ser que sofre as consequências da conduta lesiva ${ }^{192}$.
\end{abstract}

Maria Cristina Brugnara Veloso em sua dissertação de mestrado apresentada com o tema: A condição animal, também reconhece a qualidade de entes despersonificados aos animais, com base "na diferenciação de "pessoa” e "sujeito de direito", de forma que este último não dependa da qualificação de “pessoa” para titularizar direitos subjetivos, é que se inclui os animais como autênticos sujeitos de direito não personificados”. 193

Neste contexto, detecta-se que embora os animais não sejam detentores de personalidade jurídica, estes são reconhecidos como sujeitos de direito, assim como o nascituro, a massa falida, o condomínio, a herança jacente ou vacante e o espólio.

\title{
3.3 \\ O elemento determinante para o reconhecimento dos sujeitos de direitos.
}

A doutrina tradicional conceitua o sujeito de direito como aquele que é detentor da titularidade de direitos e deveres na ordem jurídica. Mas quem são estes sujeitos de direitos?

Ao longo do tempo foi consolidada uma identificação entre os conceitos de sujeito de direito e de pessoa.

\footnotetext{
${ }^{192}$ LOURENÇO, Daniel Braga. Direito dos Animais: fundamentação e novas perspectivas. Porto Alegre: Sérgio Antônio Fabris, 2008, p. 509.

${ }^{193}$ VELOSO, Maria Cristina Brugnara. A condição animal: uma aporia moderna. Dissertação (Mestrado). Pontifícia Universidade Católica de Minas Gerais. Programa de Pós-Graduação em Direito. Belo Horizonte, 2011, p. 109.
} 
Viu-se até agora que a doutrina clássica civilista classifica os sujeitos de direito como sendo apenas aquelas pessoas detentoras de personalidade jurídica, ou seja, as pessoas naturais já nascidas e as pessoas jurídicas, desde que tenham seus atos constitutivos devidamente registrados nos órgãos competentes.

Acontece que, Fábio Ulhoa Coelho, Maria Cristina Brugnara Veloso, Daniel Braga Lourenço e César Fiuza, diferentemente da doutrina majoritária clássica, reconhecem não apenas as pessoas detentoras de personalidade jurídica como sujeitos de direito, mas também certos entes que mesmo não sendo detentores de personalidade jurídica são reconhecidos como sujeitos de direito.

São eles: o nascituro, os animais, o espólio, o condomínio, a massa falida, a herança jacente ou vacante e as sociedades de fato ou irregulares.

Essa visão demonstra a necessidade de distinguir os conceitos de sujeito de direito e personalidade jurídica. De acordo com Fábio Ulhoa Coelho nem todo sujeito de direito é detentor de personalidade jurídica, consequentemente, nem todo sujeito de direito é pessoa. ${ }^{194}$

O mencionado autor ao classificar os sujeitos de direito, apresenta dois critérios: "o primeiro os divide em personificados (ou personalizados) e despersonificados (ou despersonalizados)" sujeitos de direito despersonalizados são titulares de direitos e deveres”. 196

As pessoas personificadas segundo Ulhoa recebem pelo ordenamento jurídico uma autorização genérica para ser parte nas relações jurídicas, podendo tudo o que o ordenamento não proíbe. Já os entes despersonificados não recebem autorização genérica, ou seja, não podem figurar em qualquer relação jurídica, mas somente naquelas que o próprio ordenamento lhes autoriza. ${ }^{197}$

Já no segundo critério, Ulhoa “distingue, de um lado, os sujeitos humanos (ou corpóreos) e, de outro, os não humanos (ou incorpóreos)”. 198

Os entes humanos são as pessoas naturais e surgem para o direito no momento em que são concebidos, ou seja, quando são chamados de nascituro, sendo reconhecidos como sujeitos de direito despersonificados, tornando-se, a

\footnotetext{
${ }^{194}$ COELHO, Fábio Ulhoa. Curso de direito civil: parte geral, volume 1.- 4. Ed. - São Paulo: Saraiva, 2010, p. 138.

${ }^{195}$ COELHO, Fábio Ulhoa. Curso de direito civil: parte geral, volume 1.- 4. Ed. - São Paulo: Saraiva, 2010, p. 153.

${ }^{196}$ Ibid.

${ }^{197}$ Ibid.

${ }^{198}$ Ibid.
} 
partir do momento que são concebidos, titulares de direitos personalíssimos, como o direito à vida, ao nome, aos alimentos, dentre outros, e são detentores de uma expectativa de adquirir personalidade a partir do momento que vem a nascer com vida, transformando-se em pessoa para o direito. ${ }^{199}$

Já os sujeitos de direito não humanos são os demais entes considerados despersonalizados: os animais, o espólio, o condomínio, a massa falida, a herança jacente ou vacante e as sociedades irregulares.

Para que os entes despersonificados sejam reconhecidos como sujeitos de direitos torna-se necessário que haja um elemento referencial entre eles, para que o ordenamento jurídico os reconheça como titulares de direitos e obrigações, surgindo aí várias indagações inerentes a esses entes que procure solucionar o enquadramento de todos eles como sujeitos de direitos. Assim, surgem as seguintes perguntas: qual é o elemento inerente a todos estes entes que os tornam sujeitos de direitos? Seria a vida? A expectativa ou a potencialidade que todos têm de adquirir personalidade?

Para responder a tais perguntas torna-se necessário analisar cada um dos entes reconhecidos como sujeitos de direitos despersonificados.

\subsection{1}

\section{A Massa Falida}

A discussão inicia-se com a massa falida, que passa a existir após a declaração de falência de uma pessoa jurídica regular, passando esta a ser administrada pela massa falida, que substitui o falido e é administrada por um administrador judicial nomeado pelo Poder Judiciário.

Quando é decretada a falência da pessoa jurídica, todos os seus bens passarão a ser administrados pela massa falida, somente podendo os credores se beneficiar dos bens arrecadados pela massa. A massa falida, a partir do momento que é constituída, está autorizada a praticar todos os atos necessários em nome do falido, passando a receber os créditos e a negociar todos os débitos deixados, tornando-se um sujeito de direito despersonificado.

\footnotetext{
${ }^{199}$ Ibid., p. 154.
} 
Portanto, a massa falida é "um organismo sem personalidade que, apenas para efeitos práticos, é tratado como se fosse pessoa” ${ }^{200}$, reconhecendo, o ordenamento jurídico, a este ente a chamada capacidade de fato ou de exercício ${ }^{201}$ para seus direitos e obrigações por ele mesmo, bem como capacidade processual, conforme art. 12 do Código de Processo Civil.

Dessa maneira, a massa falida é um ente despersonificado, de característica estritamente patrimonial e é sujeito de direitos, uma vez que lhe é reconhecido a capacidade de ser titular de direitos e deveres através da representação de seu administrador judicial. Mas este ente, apesar de ser sujeito de direito, em momento algum adquirirá vida ou uma expectativa de tornar-se pessoa, reconhecendo o ordenamento, independente deste ser pessoa, a aptidão para titularizar direitos e deveres.

\subsection{2 \\ O Espólio}

O espólio é outro ente reconhecido como sujeito de direito despersonificado de cunho patrimonial, surge a partir do momento que morre uma pessoa natural deixando herdeiros e um patrimônio. A pessoa falecida deixa de ser sujeito de direito, cessando com ela a personalidade.

Mas com a morte da pessoa normalmente restam obrigações, ou seja, débitos e créditos deixados pelo morto em vida, e seus bens que devem ser administrados por alguém. Para administrar os bens deixados pelo de cujus e cuidar de suas obrigações, o ordenamento jurídico criou o espólio, um ente despersonalizado que é representado pelo inventariante.

O espólio é apto a representar todos os herdeiros do de cujus, em tudo o que disser respeito aos bens e obrigações deste, sendo reconhecida, pelo ordenamento jurídico, a capacidade de participar das relações, bem como a capacidade processual, conforme os arts. 12, 985 e 986 do Código de Processo Civil.

\footnotetext{
${ }^{200}$ FIUZA, César. Direito civil: curso completo. - 8. ed., rev., atual. e ampl. - Belo Horizonte: Del Rey, 2004, p. 153.

${ }^{201}$ É a aptidão que é conferida pelo ordenamento jurídico a certas pessoas, para que estas exerçam por elas mesmas a titularidade de direitos e deveres nas relações jurídicas.
} 


\subsection{3}

\section{O Condomínio}

O condomínio "é uma situação jurídica em que duas ou mais pessoas detêm os mesmos direitos e deveres de dono sobre uma mesma coisa, a um só tempo"202. Trata-se de entidade também reconhecida pelo ordenamento jurídico brasileiro como ente despersonalizado patrimonializado.

O papel deste ente é administrar ativa e passivamente os interesses comuns, relacionados às áreas comuns, em um mesmo bem de mais de uma pessoa, detendo, assim como a massa falida e o espólio, a capacidade de participar de relações jurídicas e de figurar como parte ativa ou passiva em relações processuais, o que o torna sujeito de direitos.

Assim como os entes despersonalizados já apresentados, a este também é reconhecido pelo ordenamento jurídico a titularidade de participar de relações jurídicas e processuais, independentemente da qualidade de ser pessoa.

\subsection{4}

\section{A Herança Jacente e Vacante}

A herança jacente e vacante é definida nos artigos 1.819 e 1820 do Código Civil Brasileiro e trata-se do "mesmo fenômeno, isto é, herança que não possui herdeiro, ainda que transitoriamente. A lei lhes atribui representação processual”203, ou seja, na herança jacente e vacante o morto, em principio, não deixou herdeiros para administrar suas obrigações e seus bens, devendo o judiciário nomear um representante para administrá-los.

O ordenamento jurídico pátrio, apesar de reconhecer capacidade jurídica e processual a este ente, não o reconhece como detentor de personalidade jurídica.

\subsection{5}

\section{A Sociedade de Fato ou Irregular}

Qualquer pessoa jurídica para existir regularmente, deve registrar seus atos constitutivos nos órgãos competentes determinados pela lei. A partir do momento

\footnotetext{
${ }^{202}$ FIUZA, César. Direito civil: curso completo. - 8. ed., rev., atual. e ampl. - Belo Horizonte: Del Rey, 2004, p. 151.

${ }^{203}$ VENOSA, Silvio de Salvo. Direito civil: parte geral. - 9. ed. - São Paulo: Atlas, 2009, p. 240.
} 
que não são registrados os atos da forma que a lei determina, a personalidade a pessoa jurídica não é reconhecida, tornando-se uma sociedade irregular não personificada.

Neste norte, as sociedades de fato ou irregulares são reconhecidas pelo ordenamento jurídico brasileiro como titulares de direitos e deveres, entretanto não são detentoras de personalidade jurídica.

Assim, as sociedades irregulares são reconhecidas pelo ordenamento como entes despersonalizados patrimonializados, titulares de direitos e obrigações jurídicas, mesmo não figurando no rol das pessoas detentoras de personalidade jurídica.

\subsection{6}

\section{Os animais}

Os animais, assim como os entes descritos acima, hodiernamente, são considerados sujeitos de direito, ou seja, são detentores de diversos direitos resguardados pelo ordenamento jurídico brasileiro, conforme descrito no tópico 3.2.2, e possuem capacidade jurídica e postulatória.

Estes entes, além de ser reconhecidos como sujeito de direitos, o ordenamento, com fundamento no art. $1^{\circ}$, III da Constituição Federal de 1988, lhe confere o direito a uma vida digna.

\subsection{7 \\ O nascituro como Ente Despersonificado}

“O homem e a mulher, enquanto se encontram em processo de gestação no útero materno (nascituros), são já sujeitos de direito, embora não sejam ainda pessoas". 204

$\mathrm{O}$ art. $2^{\circ}$ do Código Civil prescreve que: "a personalidade civil da pessoa começa do nascimento com vida; mas a lei põe a salvo, desde a concepção, os direitos do nascituro”205, a ressalva acrescentada na segunda parte do artigo transcrito acaba reconhecendo que, mesmo antes do nascimento, mas desde que já

${ }^{204}$ COELHO, Fábio Ulhoa. Curso de direito civil: parte geral, volume 1.- 4. Ed. - São Paulo: Saraiva, 2010, p. 159.

${ }^{205}$ BRASIL. Código Civil e Constituição Federal. Obra coletiva de autoria da editora Saraiva com a colaboração de Antônio Luiz de Toledo Pinto, Márcia Cristina Vaz dos Santos Windt e Lívia Céspedes. - 16. ed. - São Paulo: Saraiva, 2010, p. 23. 
esteja concebido, a pessoa natural não é detentora de personalidade jurídica, "mas, como já titularizam os direitos postos a salvo pela lei, são sujeitos de direitos”. ${ }^{206}$ Mas, para que este ente venha a se tornar pessoa e adquirir personalidade jurídica, é necessário que nasça com vida, uma vez que não nascendo com vida é considerado natimorto, não se tornando pessoa e, consequentemente, não adquirindo personalidade jurídica.

Como já mencionado, três correntes tradicionais discutem a natureza jurídica do nascituro. Os defensores da teoria natalista sustentam que a personalidade jurídica somente é adquirida após o nascimento com vida. Os defensores da teoria da concepção condicional reconhecem a personalidade ao nascituro desde a concepção, mas esta personalidade está submetida à condição do nascimento com vida, já os defensores da teoria da concepção sustentam que o nascituro é detentor de personalidade jurídica, o reconhecendo como pessoa.

Contudo, nota-se que nos dias atuais as três teorias tradicionais que discutem a personalidade jurídica do nascituro, são insuficientes para solucionar o problema da natureza jurídica deste ente.

Neste contexto, a teoria dos entes despersonificados soluciona com uma maior lucidez o problema da natureza jurídica do nascituro.

A teoria dos entes sem personalidade ou despersonificados reconhece que, alguns organismos em abstrato recebem, em alguns casos, o tratamento dado às pessoas, embora não o sejam.

Portanto, a teoria dos entes despersonificados reconhece a algumas entidades sem personalidade (massa falida, espólio, condomínio, herança jacente e vacante, sociedades de fato ou irregulares, animais e o nascituro) a aptidão para titularizar direitos e obrigações, conferindo em certos casos o mesmo tratamento dado às pessoas detentoras de personalidade.

Tal teoria reconhece que toda pessoa é sujeito de direito, mas nem todo sujeito de direito é pessoa, trazendo a distinção entre pessoas e sujeitos de direito.

Destaque-se que os entes despersonificados em sua maioria são organismos com finalidade estritamente patrimonial, como é o caso da massa

\footnotetext{
${ }^{206}$ COELHO, Fábio Ulhoa. Curso de direito civil: parte geral, volume 1.- 4. Ed. - São Paulo: Saraiva, 2010, p. 159.
} 
falida, do condomínio, do espólio, da herança vacante e jacente e da sociedade de fato ou irregular.

Já o nascituro, trata-se de um ente que já foi concebido no ventre materno e que se distingue de todos aqueles entes que ainda não foram concebidos e que de uma forma ou outra possam se tornar sujeitos de direito no futuro. As sociedades de fato ou irregulares, assim como o nascituro, já existem e poderão se tornar pessoa.

Nesta esteira, nota-se que o nascituro e as sociedades irregulares são detentores de uma potencialidade de transformar-se em pessoa, adquirindo personalidade jurídica e podendo atingir a plenitude da capacidade, o que os torna diferentes dos demais entes despersonificados, uma vez que todos os outros, apesar de terem reconhecida a titularidade para adquirir direitos e deveres, não apresentam a expectativa de se tornar pessoa.

A posição do nascituro, comparada com outros entes despersonificados, e, em especial, com as sociedades de fato ou irregulares, é peculiar, pois o nascituro possui um regime protetivo de cunho existencial no ordenamento jurídico, embora não tenha todos os requisitos da personalidade.

Desse modo, de acordo com o ordenamento jurídico pátrio, embora o nascituro não seja considerado pessoa, tem, legalmente protegidos, desde a concepção, direitos como: o reconhecimento voluntário de filiação, o direito a alimentos ainda no ventre materno, o direito a integridade física, o direito a ter um nome - mesmo nascendo morto -, o direito ao dano moral, dentre outros.

O nascituro ainda carrega uma peculiaridade que o diferencia das sociedades de fato ou irregulares. Além da expectativa de adquirir personalidade, ele é um ente despersonificado de natureza existencial, enquanto as sociedades de fato ou irregulares em consonância com os demais entes despersonificados (exceto os animais), são detentores de uma natureza estritamente patrimonial, conforme se demonstra no quadro sinótico a seguir: 


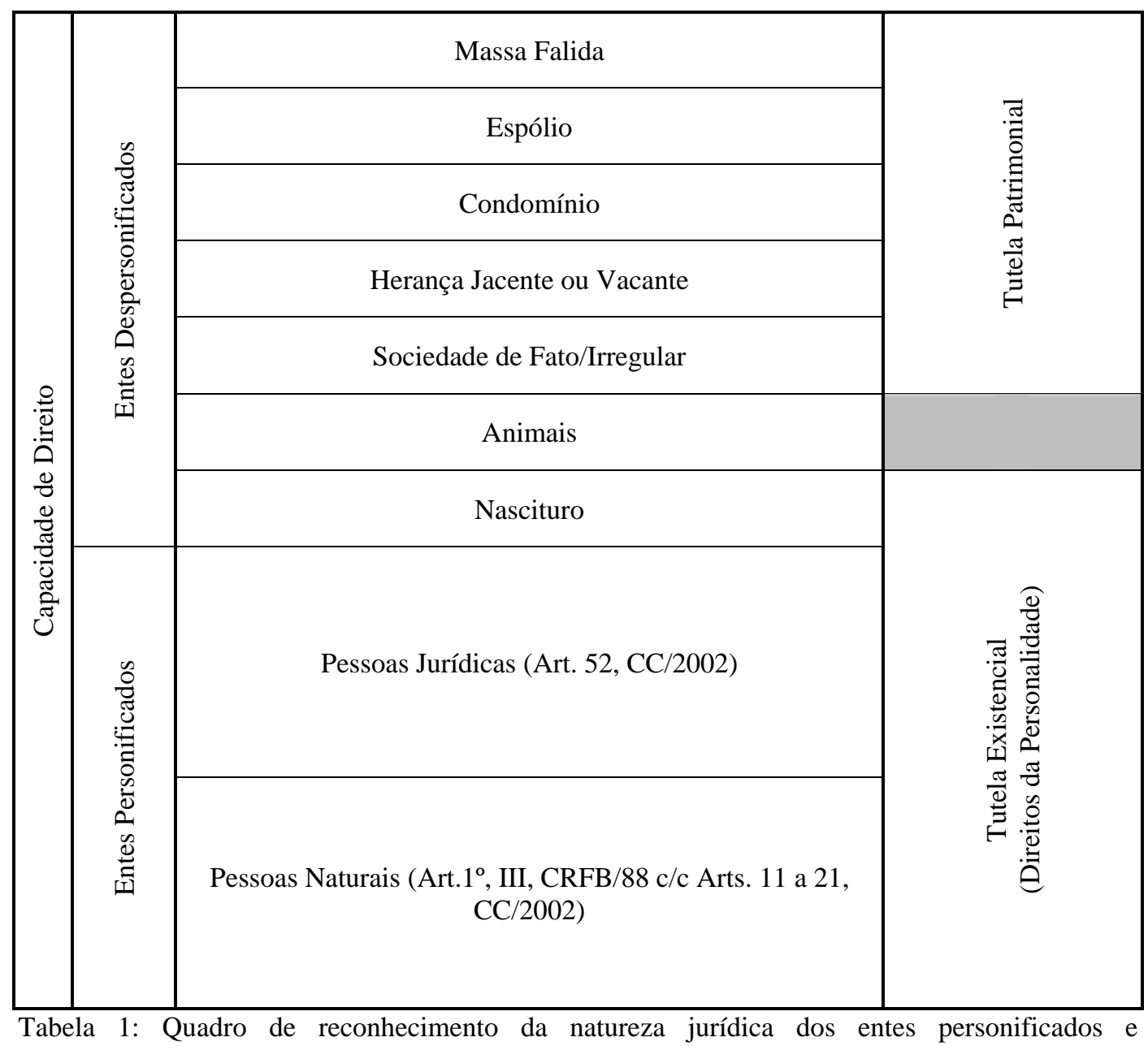
despersonificados.

Portanto, detecta-se que o ordenamento jurídico, embora não reconheça a personalidade, reconhece vários direitos personalíssimos ao nascituro, que além de ser detentor de inúmeros direitos, é também detentor de uma expectativa de se tornar pessoa, ou seja, passado o prazo gestacional da mãe e vindo a nascer com vida, ele adquire personalidade jurídica, podendo se tornar plenamente capaz com o passar dos anos e exercer todos os atos da vida civil por ele mesmo.

Vale salientar ainda que, a partir do momento que são reconhecidos direitos personalíssimos ao nascituro, o ordenamento, a doutrina e a jurisprudência reconhecem este ente como se pessoa fosse, figurando como sujeito de relações jurídicas existenciais.

Portanto, mesmo o nascituro sendo um ente despersonificado, assim como a massa falida, o espólio, o condomínio, a herança jacente e vacante, a sociedade de fato ou irregular e os animais, ele carrega um grande diferencial dos demais 
que é a sua natureza existencial, enquanto os outros entes despersonificados são detentores de uma patrimonialidade necessária em sua natureza.

Assim, apesar do art. $2^{\circ}$ do Código Civil brasileiro ter como principal característica a patrimonialidade, através da aplicação da metodologia civilconstitucional, esta norma deve ser interpretada com ênfase ao seu caráter existencial, reconhecendo a partir deste artigo a tutela a direitos da personalidade do nascituro, tratando-o como se pessoa fosse.

No próximo capítulo serão apresentados diversos direitos existenciais do nascituro com amparo no ordenamento jurídico brasileiro, na doutrina e na jurisprudência pátria, para confirmar a aptidão que este ente detém para ser sujeito de direitos, vir a se tornar pessoa e adquirir personalidade jurídica. 


\section{4 \\ Das Tutelas Existenciais do Nascituro}

Falar em direitos do nascituro é uma atividade de grande complexidade, uma vez que o ordenamento jurídico brasileiro não reconhece personalidade a este ente.

Contudo, o próprio ordenamento lhe confere a titularidade de ser sujeito de direito em relações jurídicas, o que desperta várias dúvidas relativas à natureza jurídica do nascituro, como: antes de adquirir personalidade jurídica quais são os direitos que o nascituro detém? Adquirindo direitos e obrigações antes de adquirir personalidade seria possível observar uma capacidade ao nascituro?

Portanto, neste capítulo procurar-se-á apresentar algumas situações jurídicas de cunho existencial em que o ordenamento jurídico reconhece o nascituro como titular desses direitos, o que leva a proposição de confirmar que, mesmo não sendo detentor de personalidade jurídica, o nascituro é sujeito de direitos, reconhecendo a este a capacidade de figurar como titular de situações jurídicas existenciais, classificando-o como um ente despersonificado.

\section{1 \\ Direito à Vida}

Antes de analisar o que é o direito à vida, é necessário verificar o sentido ou definição da expressão "vida”. Neste norte, para Benedita Inêz Lopes Chaves “vida” é:

[...] a oportunidade de virmos a este planeta para as diversas realizações, não cabendo, nestes breves estudos, rumar para questões de alta indagação sobre a relação entre os homens e Deus, mesmo porque, além do conhecimento científico, envolveria questões relativas ao sentimento e entendimento de cada ser humano. Dada a sua importância é dever do Estado reconhecer e proteger a inviolabilidade do direito à vida, garantido pela Constituição Federal que, no entanto, não estabelece o momento em que se daria esta proteção. ${ }^{207}$

Benedita Inêz acrescenta ainda que:

${ }^{207}$ CHAVEZ, Benedita Inêz Lopes. A tutela jurídica do nascituro. - São Paulo: LTr, 2000, p. 53. 
A vida e a integridade física e psíquica são inerentes à condição humana, não derivando de nenhum ordenamento jurídico. O homem já nasce com tais atributos, independentemente de qualquer sistema jurídico, ou social, a que pertença. É um dom conferido pela própria natureza ao homem, e não uma criação legal, pois o direito positivo tem apenas a função de protegê-la, em relação a cada indivíduo e à sociedade. ${ }^{208}$

Dessa forma, deve-se entender a vida em dois aspectos: o natural, que é inerente à condição humana, estendido a qualquer espécie humana, independentemente do seu estado físico ou psíquico, e o jurídico, que tem como função a proteção da pessoa.

Sendo assim, o direito à vida é considerado o direito primordial do ser humano $^{209}$, é o mais fundamental de todos os direitos assegurados ao homem, pois é pré-requisito à existência e exercício de todos os demais direitos. ${ }^{210}$

O direito à vida está resguardado no caput do artigo $5^{\circ}$ da Constituição Federal, assim prescrito: “Todos são iguais perante a lei, sem distinção de qualquer natureza, garantindo-se aos brasileiros e aos estrangeiros residentes no País a inviolabilidade do direito à vida, à liberdade, à igualdade, à segurança e à propriedade״ ${ }^{211}$. Trata-se, portanto, de um direito individual, fundamental e inviolável, sendo devidamente resguardado a todas as pessoas, indistintamente.

Neste sentido, “a vida é o principal direito do ser humano, cabendo ao Estado preservá-lo desde a sua concepção, sendo que nenhum interesse estatal pode superá-lo"212. É, portanto, o direito que atinge a todos, sem qualquer restrição, tanto os que já foram concebidos, mas ainda não nasceram, como os já nascidos.

Silmara Chinelato ao discorrer sobre o direito à vida do nascituro afirma que quando a mãe encontra-se em risco de morte, deve-se analisar o direito à vida do nascituro, devendo equilibrar na mesma balança o direito da pessoa que já é nascida com a do nascituro. A autora acrescenta que tal situação configura o estado de necessidade invocado pelo Direito Penal:

\footnotetext{
${ }^{208}$ Ibid., p. 54.

${ }^{209}$ ALMEIDA, Silmara J. A. Chinelato e. Tutela civil do nascituro. - São Paulo: Saraiva, 2000, p. 293.

${ }^{210}$ MORAES, Alexandre de. Direito constitucional. 20. ed. - São Paulo: Atlas, 2006, p. 30.

${ }^{211}$ BRASIL. Código Civil e Constituição Federal. Obra coletiva de autoria da editora Saraiva com a colaboração de Antônio Luiz de Toledo Pinto, Márcia Cristina Vaz dos Santos Windt e Lívia Céspedes. - 16. ed. - São Paulo: Saraiva, 2010, p. 18.

${ }^{212}$ CHAVEZ, Benedita Inêz Lopes. A tutela jurídica do nascituro. - São Paulo: LTr, 2000, p. 53.

${ }^{212}$ Ibid., p. 55.
} 
Problema de maior complexidade é o aborto resultante de estupro que, no campo do Direito Civil, representa ofensa à integridade física e psíquica da mãe, bem como a integridade familiar - direitos da personalidade. Tais direitos e valores são sopesados pelo legislador e não podem ser ignorados pelo jurista. Esse é um dos assuntos mais polêmicos do Direito Penal e do Direito Civil. O raciocínio puramente jurídico e, em tese, a coerência absoluta - difícil de alcançar em questão que não é só jurídica - levariam à defesa da vida do nascituro e seu encaminhamento à adoção. O legislador, porém reconheceu que a hipótese deveria sopesar outros aspectos - sociais, psicológicos, antropológicos - em favor da mulher, vítima de crime.

A partir da discussão levantada por Chinelato, compreende-se que é resguardado o direito à vida do nascituro e que este direito quando vai de encontro com o perigo de morte da mãe gerando a necessidade de escolha de vida de um ou de outro, o julgador deve analisar não apenas a legislação literal, mas incorrer em uma análise mais aprofundada, sopesando vários aspectos.

Neste norte, identifica-se que o direito à vida do nascituro, assim como outros direitos que serão apresentados, caracteriza o reconhecimento da capacidade jurídica a este ente, tornando-o sujeito de direitos, ou seja, mesmo o ordenamento não reconhecendo o nascituro como pessoa, garante a ele o direito a vida como se pessoa fosse.

Além de a Constituição Federal dispor acerca do direito à vida, a legislação infraconstitucional, em várias outras circunstâncias, reconhece este direito ao nascituro. Como nos artigos 121 a 127 do Código Penal, que criminaliza o aborto, o infanticídio e o homicídio. ${ }^{213}$

No mesmo sentido, foi ratificado pelo Brasil, entrando no direito interno por meio do Decreto $\mathrm{n}^{\circ}$ 678, de 06 de novembro de 1992, o Pacto de San José da Costa Rica ou Convenção Americana de Direitos Humanos de 1969 que também reconhece o direito à vida do nascituro em seu art. $4^{0^{214}}$.

Maria Cristina Zainaghi acrescenta, no que diz respeito ao direito à vida do nascituro, o art. $8^{\circ}$ do Estatuto da Criança e do Adolescente (Lei n ${ }^{\circ} 8.069$ de 13 de

\footnotetext{
${ }^{213}$ ALMEIDA, Silmara J. A. Chinelato e. Tutela civil do nascituro. - São Paulo: Saraiva, 2000, p. 298.

214 “Art. $4^{\circ}$ - Direito à vida: 1. Toda pessoa tem direito a que se respeite sua vida. Esse direito deve ser protegido pela lei e, em geral, desde o momento da concepção. Ninguém pode ser privado da vida arbitrariamente”. ALMEIDA, Silmara J. A. Chinelato e. Tutela civil do nascituro. - São Paulo: Saraiva, 2000, p. 299.
} 
julho de 1990$)^{215}$, que assegura o pré-natal, e, principalmente, assegura uma proteção integral e, consequentemente, o direito a uma tutela jurisdicional diferenciada a este ente. ${ }^{216}$

O direito à vida é, senão, o ensejo do ser humano em ter uma vida digna, e dele decorrem outros direitos que estão conectados, como o direito à intimidade, à convivência familiar, à privacidade, à honra, ao corpo, à imagem e diversos direitos previstos na Constituição Federal. Portanto, o direito à vida também resguarda o ente que ainda não nasceu, mas que, futuramente, se não houver a intervenção humana, ou mesmo da natureza, poderá vir a nascer.

Portanto, o nascituro desde a concepção já existe, precisamente em virtude da potencialidade de vir a nascer com vida, sendo que a ele é assegurado o direito de nascer, se desenvolver e crescer.

Francesco D’Agostino, citado por Maria Cristina Zainaghi, ao tratar dos direitos reconhecidos ao nascituro, descreve que:

\begin{abstract}
Voltemos ao inicio do nosso discurso. Quais direitos são reconhecidos a um nascituro? Havia-se respondido: só um, o de nascer. Ao fim de todas essas considerações, esta resposta, ainda que simplicíssima, continua a apresentar-se ainda como a mais adequada à pergunta. $\mathrm{O}$ direito de nascer é mesmo o primeiro de todos os direitos, não só - como poderia parecer sobre as primeiras - em sentido cronológico, mas, sobretudo em sentido axiológico: o direito de nascer inclui o primeiro de todos os direitos da pessoa e estabelece todos os direitos constitutivos da pessoa, os direitos a serem respeitados a própria identidade, em não serem instrumentalizados por alguma razão, em serem considerados como portadores de uma dignidade especifica, irreduzível a qualquer outro ser humano, direito, em conclusão, em ser reconhecido como pessoa. ${ }^{217}$
\end{abstract}

Assim, detecta-se que o nascituro é titular do direito personalíssimo da vida. Ficando caracterizado, conforme já afirmado, que o nascituro não possui personalidade civil, tampouco é uma pessoa, mas é tratado como se pessoa fosse.

\footnotetext{
215 “Art. $8^{\circ}$ - É assegurado à gestante, através do Sistema Único de Saúde, o atendimento pré e perinatal.

$\S 1^{\circ}$ - A gestante será encaminhada aos diferentes níveis de atendimento, segundo critérios médicos específicos, obedecendo-se aos princípios de regionalização e hierarquização do sistema.

$\S 2^{\circ}$ - A parturiente será atendida preferencialmente pelo mesmo médico que a acompanhou na fase pré-natal.

$\S 3^{\circ}$ - Incumbe ao Poder Público propiciar apoio alimentar à gestante e à nutriz que dele necessitem. BRASIL. Lei $n^{o} 8.069$ de 13 de julho de 1990. Que dispõe sobre o Estatuto da Criança $e$ do Adolescente $e$ dá outras providências. Disponível em: http://www.planalto.gov.br/ccivil_03/leis/18069.htm. Acesso em: 17 de janeiro de 2014.

${ }^{216}$ ZAINAGHI, Maria Cristina. Os meios de defesa dos direitos do nascituro. - São Paulo: LTr, 2007, p. 26.

217 D“AGOSTINO Apud ZAINAGHI, Maria Cristina. Os meios de defesa dos direitos do nascituro. - São Paulo: LTr, 2007, p. 28.
} 


\section{2 \\ Direito à Integridade Física}

Silmara Chinelato reconhece que o nascituro é “pessoa, biológica e juridicamente, se sua integridade física e sua saúde não se confundem com as da mãe, ainda que com ela o concebido mantenha relação de dependência, não há como negar-lhe direito à integridade física e à saúde [...]”. 218

O direito à integridade física concerne à proteção jurídica do corpo humano, isto é, se protege à incolumidade do corpo vivo e morto da pessoa, alcançando tanto o nascituro, como o corpo sem vida (cadáver) ${ }^{219}$, além dos tecidos, órgãos e partes suscetíveis de separação e individualização. ${ }^{220}$

Neste sentido, identifica-se que a pessoa detém uma especial proteção referente a seu corpo, impondo sanção a qualquer ato que importe à violação à sua integridade física.

A proteção à integridade física, de acordo com Cristiano Chaves e Nelson Rosenvald, "tem início desde a concepção, estendida até a morte, representada pela paralisação da atividade cerebral, circulatória e respiratória”.221

A integridade física post mortem, é regulamentada na Lei ${ }^{\circ}$ 9.434/1997, bem como nos artigos 209 a 212 do Código Penal ${ }^{222}$, e não deve ser reconhecida

\footnotetext{
${ }^{218}$ ALMEIDA, Silmara J. A. Chinelato e. Tutela civil do nascituro. - São Paulo: Saraiva, 2000, p. 315.

${ }^{219}$ O Código Civil Brasileiro prescreve que a existência da pessoa natural termina com a morte (art. $6^{\circ}$ ), e sua prova deve constituir-se da certidão de óbito (art. $9^{\circ}$, I), sem a qual não se deve realizar o sepultamento do cadáver.

Neste sentido, pode-se afirmar que a morte é o fim dos direitos inerentes à personalidade? Ou seja, a morte cessa os direitos da pessoa?

A doutrina clássica civilista reconhece os direitos da personalidade à existência da pessoa. Sobre o início e fim da personalidade jurídica manifesta-se Caio Mário da Silva Pereira "a personalidade é um atributo do ser humano e o acompanha por toda a vida. Como a existência da pessoa natural termina com a morte, somente com esta cessa a sua personalidade”. PEREIRA, Cáio Mário da Silva. Instituições de direito civil. - 24 ed. - Rio de Janeiro: Forense, 2011, p. 186.

Assim, a morte representa o fim da pessoa natural e o corpo dessa pessoa denomina-se cadáver.

Maria de Fátima Freire de Sá e Bruno Torquato de Oliveira Naves afirmam que o "morto não tem personalidade, não é detentor de direitos, [...].”SÁ, NAVES, Maria de Fátima Freire de, Bruno Torquato de Oliveira. Manual de biodireito. $2^{\mathrm{a}}$ ed. - Belo Horizonte: Del Rey, 2011, 80.

${ }^{220}$ FARIAS, ROSENVALD, Cristiano Chaves de, Nelson. Direito Civil: teoria geral. $9^{\mathrm{a}}$ ed., Rio de Janeiro: Lumen Juris, 2011, 118.

${ }^{221}$ Ibid., p. 118.

${ }^{222}$ A Lei n ${ }^{\circ}$ 9.434/97 regulamenta o transplante de órgãos, tecidos e partes do corpo humano vivo ou morto. Já os artigos 209 a 212 do Código Penal tratam dos crimes contra o respeito aos mortos. Vale lembrar que para a ocorrência da doação após a morte é necessária a manifestação de vontade em vida do doador para que esta produza seus efeitos. Caso o falecido não tenha manifestado em vida sua vontade de doar órgão, no caso de morte, a decisão passa a ser de seus herdeiros. Tanto os crimes cometidos contra o respeito aos mortos, como a Lei de transplante não reconhecem direitos ao cadáver, mas o respeito a eles. Isso comprova mais uma vez o não reconhecimento de
} 
como direitos do cadáver, pois, “o morto não tem personalidade, não é detentor de direitos, não se insere em uma relação jurídica intersubjetiva, não obstante a imputação de responsabilidade àquele que infringiu uma esfera de não liberdade.”223 “"mas sobre ele consubstancia-se a situação de dever jurídico ${ }^{224}$.”

Quando se trata da integridade física e da saúde do nascituro, não se pode confundi-las com as da mãe, sendo ilícito a esta opor-se aos direitos do nascituro, pois eles são do ente já concebido em seu ventre.

Neste interim, Silmara Chinelato afirma que:

[...]. Assim sendo, não pode a mãe recusar-se a ingerir medicamento destinado a preservar a saúde do filho nem a submeter-se a intervenção médica que vise a dissolver medicamento no líquido amniótico, que o feto engole instintivamente.

Ainda que, na prática, tal recusa possa ensejar situações de fato de difícil solução, do ponto de vista jurídico ela se nos apresenta clara e inequívoca: não cabe à mãe dispor de direito à vida e à saúde que não é seu, mas sim do filho nascituro. Pela omissão poderá ser civilmente responsabilizada. ${ }^{225}$

Nesta esteira, com o reconhecimento do direito à integridade física do ente por nascer, formaram-se diversas opiniões, sendo que até mesmo os pais, que violam direitos à integridade física do nascituro, são obrigados a reparar o dano causado, conforme passagem a seguir:

Logo se formaram opiniões reconhecendo, por exemplo, ao filho, afetado de sífilis ou de Aids, o direito de ser ressarcido por seus pais, considerados responsáveis por lhe ter causado o dano, no momento em que o geraram, conscientes de que se corria o risco de transmitir essa enfermidade. Umas, entendendo que não se admite qualquer tipo de pedido de ressarcimento contra os

capacidade jurídica e muito menos de personalidade jurídica ao cadáver, uma vez que ele não é detentor de direitos. Assim, “à família não são transferidos 'direitos da personalidade', mas é-lhe atribuída uma esfera de liberdade processual na defesa da não-infração de deveres que se refiram à 'figura' do morto”. SÁ, NAVES, Maria de Fátima freire de, Bruno Torquato de Oliveira. Manual de biodireito. $2^{\mathrm{a}}$ ed. - Belo Horizonte: Del Rey, 2011, 80.

${ }^{223}$ SÁ, NAVES, Maria de Fátima freire de, Bruno Torquato de Oliveira. Manual de biodireito. $2^{\mathrm{a}}$ ed. - Belo Horizonte: Del Rey, 2011, 80.

224 "Este dever tem-no como objeto de proteção. Dessa forma, não faz sentido se avaliar a personalidade do morto, seja na sua integralidade, seja como mero reflexo. Para melhor entendimento, poderíamos fazer um paralelo entre o morto e a situação do nascituro ou dos entes despersonalizados. Naquele caso, cessaram-se quaisquer possibilidades de exercício de uma autonomia privada. Se o direito imputa situações jurídicas ao nascituro ou aos entes despersonalizados o faz, jurídica e principiologicamente, em razão do exercício futuro da autonomia de uma pessoa física (nascituro) ou da realização de uma atividade personificada. Portanto, se alguém lesiona a 'honra ou a imagem do morto', não ofende direitos - até porque esses não existem -, mas viola deveres”. SÁ, NAVES, Maria de Fátima freire de, Bruno Torquato de Oliveira. Manual de biodireito. $2^{\mathrm{a}}$ ed. - Belo Horizonte: Del Rey, 2011, 80.

${ }^{225}$ ALMEIDA, Silmara J. A. Chinelato e. Tutela civil do nascituro. - São Paulo: Saraiva, 2000, p. 315. 
pais, porque seria imoral, pois o Direito, em respeito à privacidade, protege e garante a liberdade sexual. Outras sustentam a viabilidade da pretensão indenizatória, porque os pais têm que ser conscientes de seus atos, responsáveis pelo que vai nascer, constituindo-se a responsabilidade civil por dano genético, na medida correta para a proteção jurídica do nascituro. ${ }^{226}$

O caso apresentado trata-se de um problema complexo para o direito, tendo de um lado o direito à integridade física do nascituro e de outro o direito à intimidade dos pais. Não se discute neste trabalho a ocorrência de hierarquia entre esses direitos e nem a solução para tal problema, mas apenas o reconhecimento de um direito ao concebido, mas ainda não nascido, o que o legitima a figurar como titular de direitos tornando-o sujeito de direitos.

Assim, a legislação e jurisprudência pátrias têm reconhecido a titularidade de direitos personalíssimos ao nascituro, como o direito à vida, à saúde e à integridade física, devendo inclusive, quando ocorrer uma violação desses direitos, o responsável pela violação de um dever ressarcir a vítima, que no caso em discussão trata-se do nascituro.

\section{3}

\section{Direito à filiação}

Para Flávio Tartuce “a filiação é a relação existente entre ascendentes e descendentes de primeiro grau, ou seja, entre pais e filhos”227, e tal relação deve ser regida pelo princípio da igualdade entre os filhos, conforme previsto no art. 227, § $6^{\circ}$ da Constituição Federal e o art. 1.596 do Código Civil.

Benedita Chavez observa que o status de filiação está intimamente ligado ao problema do nascituro, uma vez que as relações de parentesco iniciam no momento da concepção, formando a partir desse momento um elo jurídico que perdurará por toda a vida, unindo os pais ao filho. ${ }^{228}$

Portanto, é direito dos pais saber se o nascituro é seu filho desde o momento que este foi concebido.

A filiação, entre as várias relações de parentesco, é a mais importante de todas, exatamente por causa do vínculo criado entre pais e filhos. Cristiano Chaves de Farias e Nelson Rosenvald, sobre a filiação, assim ensinam:

${ }^{226}$ CHAVEZ, Benedita Inêz Lopes. A tutela jurídica do nascituro. - São Paulo: LTr, 2000, p. 5758.

${ }^{227}$ TARTUCE, Flávio. Manual de direito civil. - Rio de Janeiro: Forense, 2011, p. 1.113.

${ }^{228}$ CHAVEZ, Benedita Inêz Lopes. A tutela jurídica do nascituro. - São Paulo: LTr, 2000, p. 85. 
É certo e incontroverso que, dentre as múltiplas relações de parentesco, a mais relevante, dada a proximidade do vínculo estabelecido e a sólida afetividade decorrente, é a filiação, evidenciando o liame existente entre pais e filhos, designado de paternidade ou maternidade, sob a ótica dos pais. ${ }^{229}$

A Constituição Federal de 1988 e o Código Civil de 2002, ao proteger a categoria dos filhos, deixa de classificá-los como legítimos (filhos nascidos no seio do casamento) e ilegítimos (filhos nascidos fora da célula familiar), não importando que este filho adveio de um casamento ou de uma união livre, classificando todo ser humano que nasce, como simplesmente filho, sem a ocorrência de qualquer discriminação.

Assim prescreve o art. 227, § $6^{\circ}$ da Constituição:

Art. 227 - É dever da família, da sociedade e do Estado assegurar à criança e ao adolescente, com absoluta prioridade, o direito à vida, à saúde, à alimentação, à educação, ao lazer, à profissionalização, à cultura, à dignidade, ao respeito, à liberdade e à convivência familiar e comunitária, além de colocá-los a salvo de toda forma de negligência, discriminação, exploração, violência, crueldade e opressão.

$[\ldots]$

$\S 6^{\circ}$ Os filhos havidos ou não da relação do casamento, ou por adoção, terão os mesmos direitos e qualificações, proibidas quaisquer designações discriminatórias relativas à filiação. ${ }^{230}$

Demonstra o referido dispositivo um grande avanço da sociedade democrática, uma vez que o Constituinte se ateve para uma proteção maior dos filhos, estabelecendo que toda pessoa já concebida, independentemente de qual a natureza do relacionamento de seus pais, é simplesmente filho, atribuindo os mesmos direitos a todos. ${ }^{231}$

Para estabelecer o nexo de filiação, deve ser levado em consideração o concurso de quatro elementos, a saber: a cópula, a derivação biológica do casal, a gestação materna e o nascimento dentro do período legal da concepção. ${ }^{232}$

No entanto, Benedita Inêz afirma que a cópula deixou de ser indispensável, sendo apenas a derivação biológica necessária, porém insuficiente

\footnotetext{
${ }^{229}$ FARIAS, ROSENVALD, Cristiano Chaves de, Nelson. Direito das famílias. - Rio de Janeiro: Lumen Juris, 2009, p. 537.

${ }^{230}$ BRASIL. Código Civil e Constituição Federal. Obra coletiva de autoria da editora Saraiva com a colaboração de Antônio Luiz de Toledo Pinto, Márcia Cristina Vaz dos Santos Windt e Lívia Céspedes. - 16. ed. - São Paulo: Saraiva, 2010, p. 132-133.

${ }^{231}$ CHAVEZ, Benedita Inêz Lopes. A tutela jurídica do nascituro. - São Paulo: LTr, 2000, p. 85.

${ }^{232}$ Ibid., p. 86.
} 
na caracterização da filiação, devendo a paternidade hoje estar relacionada com a relação sexual. $^{233}$

O direito à filiação, em sua nova concepção, evidencia no instituto uma nova estrutura, passando, então, a ser compreendido como um instrumento de proteção ao desenvolvimento da personalidade da pessoa, reconhecendo a possibilidade dos filhos terem acesso a sua parentalidade sem sofrer nenhuma discriminação.

Dessa forma, o direito de reconhecimento da filiação, também é próprio do nascituro, conforme prescrito no parágrafo único do artigo 1.609 do Código Civil, onde há a possibilidade do reconhecimento da filiação mesmo antes do nascimento, in verbis:

Art. 1.609. O reconhecimento dos filhos havidos fora do casamento é irrevogável e será feito:

I - no registro do nascimento;

II - por escritura pública ou escrito particular, a ser arquivado em cartório;

III - por testamento, ainda que incidentalmente manifestado;

IV - por manifestação direta e expressa perante o juiz, ainda que o reconhecimento não haja sido o objeto único e principal do ato que o contém.

Parágrafo único. O reconhecimento pode preceder o nascimento do filho ou ser posterior ao seu falecimento, se ele deixar descendentes. ${ }^{234}$

Dessa forma, identifica-se que o reconhecimento de filiação pode ocorrer antes do nascimento, desde que o nascituro tenha sido concebido.

Neste sentido manifesta Silvio de Salvo Venosa:

A perfilhação pode anteceder ao nascimento se o filho já estiver concebido e também pode ser feita após sua morte, se o filho deixar descendentes (art. 1.609 parágrafo único; antigo, art. 357 parágrafo único; na. 26 da Lei 8.069/90). Quanto ao reconhecimento do já concebido, recordemos que a personalidade começa com o nascimento, mas a lei resguarda os direitos do nascituro (as. $2^{\circ}$; antigo, art. $4^{\circ}$ ). A perfilhação antes do nascimento pode representar uma cautela do pai que tenha receio de sua morte prematura, por exemplo, assegurando a certeza de paternidade ao futuro filho. ${ }^{235}$

O Estatuto da Criança e do Adolescente (Lei 8.069/90) em seu art. 26, assim como o Código Civil, reconhece o direito à filiação do nascituro.

\footnotetext{
${ }^{233}$ Ibid., p. 86.

${ }^{234}$ BRASIL. Código Civil e Constituição Federal. Obra coletiva de autoria da editora Saraiva com a colaboração de Antônio Luiz de Toledo Pinto, Márcia Cristina Vaz dos Santos Windt e Lívia Céspedes. - 16. ed. - São Paulo: Saraiva, 2010, p. 215-216.

${ }^{235}$ VENOSA, Silvio de Salvo. Direito civil: direito de família. São Paulo: Atlas, 2009, p. 307.
} 
Art. 26. Os filhos havidos fora do casamento poderão ser reconhecidos pelos pais, conjunta ou separadamente, no próprio termo de nascimento, por testamento, mediante escritura ou outro documento público, qualquer que seja a origem da filiação.

Parágrafo único. O reconhecimento pode preceder o nascimento do filho ou suceder-lhe ao falecimento, se deixar descendentes. ${ }^{236}$

Neste sentido, vem decidindo o Tribunal de Justiça de Minas Gerais, reconhecendo o direito do nascituro de figurar no pólo ativo de ação de investigação de paternidade, conforme ementa abaixo:

Ementa: FAMÍLIA. INVESTIGAÇÃO DE PATERNIDADE E ALIMENTOS. NATUREZA PERSONALÍSSIMA DA AÇÃO. LEGITIMIDADE ATIVA. DIREITO DO NASCITURO. São legitimados ativamente para a ação de investigação de paternidade e alimentos o investigante, o Ministério Público, e também o nascituro, representado pela mãe gestante. (TJMG - Apelação Cível $n^{0}$ 1.0024.04.377309-2/001 3773092-68.2004.8.13.0024 (1), Rel. Des. Duarte de Paula, julgado em 10/03/2005). ${ }^{237}$

No mesmo sentido, o Tribunal de Justiça de Santa Catarina vem reconhecendo o direito à investigação de paternidade ao nascituro.

Ementa: AGRAVO DE INSTRUMENTO. INVESTIGAÇÃO DE PATERNIDADE CUMULADA COM ALIMENTOS GRAVÍDICOS. ALIMENTOS À GESTANTE FIXADOS PROVISORIAMENTE EM 20\% DO SALÁRIO MÍNIMO. ALEGAÇÃO DE FALTA DE PROVA DE PATERNIDADE. MITIGAÇÃO DAS EXIGÊNCIAS PROBATÓRIAS EM PROL DOS INTERESSES DOS NASCITUROS, SOBRETUDO EM GARANTIA DO DIREITO FUNDAMENTAL À VIDA. ELEMENTOS QUE DENOTAM O ENVOLVIMENTO DO AGRAVANTE COM A FUTURA MÃE, A DESPEITO DE SER CASADO. GRAVIDEZ GEMELAR CONSIDERADA DE ALTO RISCO, A DEMANDAR MAIORES DESPESAS, ALÉM DE CUIDADOS EXCEPCIONAIS PARA ASSEGURAR A SAÚDE DA MULHER E DOS BEBÊS. POSTERIOR NASCIMENTO DAS CRIANÇAS (E REALIZAÇÃO DO DNA) TORNANDO INEQUÍVOCO O VÍNCULO GENÉTICO, ATÉ ENTÃO NEGADO PELO AGRAVANTE. ALIMENTOS GRAVÍDICOS DEVIDOS, NOS TERMOS DA DECISÃO RECORRIDA. RECURSO CONHECIDO E DESPROVIDO.

A mitigação do elemento probatório em ações dessa natureza justifica-se pela

\footnotetext{
${ }^{236}$ BRASIL. Código Civil e Constituição Federal. Obra coletiva de autoria da editora Saraiva com a colaboração de Antônio Luiz de Toledo Pinto, Márcia Cristina Vaz dos Santos Windt e Lívia Céspedes. - 16. ed. - São Paulo: Saraiva, 2010, p. 418.

${ }^{237}$ Disponível em:

http://www5.tjmg.jus.br/jurisprudencia/pesquisaPalavrasEspelhoAcordao.do?palavras=investiga\% E7\%E3o+de+paternidade+nascituro\&numeroRegistro=1\&totalLinhas=1\&pesquisarPor=ementa\& pesquisaTesauro=true\&orderByData=1\&pesquisaPalavras=Pesquisar. Acesso em 22 de janeiro de 2014.
} 
opção feita em prol do nascituro garantido-lhe, a despeito de maiores digressões, o direito fundamental à vida. Para tanto, pode o julgador embasar sua convicção de paternidade em meros indícios, ressalvando que, em casos de comprovada má-fé da gestante, também o princípio da irrepetibilidade dos alimentos pode sofrer ponderação. (TJSC Agravo de Instrumento $\mathrm{n}^{\circ}$ 2013.002438-5, Rel. Des. Ronei Danielli, julgado em $18 / 04 / 2013){ }^{238}$

Assim, conforme exposto, o reconhecimento da filiação pode preceder o nascimento. Mesmo o nascituro não sendo detentor de personalidade jurídica, o ordenamento jurídico lhe reconhece capacidade em termos de filiação, demonstrando mais uma vez que o nascituro é sujeito de direitos.

\section{4 \\ Direito à adoção}

O instituto da adoção, segundo Benedita Inêz, "tem por objetivo, por um lado, dar filhos àqueles a quem a natureza negou e, por outro, uma finalidade assistencial sendo este instituto jurídico, talvez, o mais belo porque envolve, intimamente, a figura da criança e dos pais que não tiveram a alegria de ter filhos”. 239

Ensina Maria Berenice Dias que “a adoção é um ato jurídico em sentido estrito, cuja eficácia está condicionada à chancela judicial. Cria um vínculo fictício de paternidade-maternidade-filiação entres pessoas estranhas, análogo ao que resulta da filiação biológica” ${ }^{240}$. Neste sentido, nota-se que o instituto da adoção apresenta duas funções: a de dar filhos a quem a natureza não os favoreceu e oferecer um lar e afetividade às crianças cujos pais biológicos não puderam lhes dar.

Quanto à adoção do nascituro, Benedita Inêz afirma tratar de questão controversa na doutrina brasileira. Segundo a autora, a maioria da doutrina entende que não deve ser reconhecida a adoção de um ser ainda não nascido e que não se sabe se vai nascer com vida. ${ }^{241}$

\footnotetext{
${ }^{238}$ Disponível em: http://app.tjsc.jus.br/jurisprudencia/busca.do. Acesso em: 22 de janeiro de 2014.

${ }^{239}$ CHAVEZ, Benedita Inêz Lopes. A tutela jurídica do nascituro. - São Paulo: LTr, 2000, p. 89.

${ }^{240}$ DIAS, Maria Berenice. Manual de direito das famílias. 5. ed. São Paulo: RT, 2009, p. 434.

${ }^{241}$ CHAVEZ, Benedita Inêz Lopes. A tutela jurídica do nascituro. - São Paulo: LTr, 2000, p. 90.
} 
Entretanto, há opiniões favoráveis à adoção do nascituro, como Sérgio Abdalla Semião que descreve o seguinte: “[...] não podemos chegar ao cúmulo de dizer que não há, implicitamente, o direito do nascituro de ser adotado [...]”242, acertadamente reconhecendo o direito à adoção do nascituro.

O Código Civil de 1916 previa a possibilidade de adotar o nascituro, em seu art. $372^{243}$, até que entrou em vigor a Lei ${ }^{\circ}$ 8.069/90 (Estatuto da Criança e do Adolescente) que revogou o previsto no Código de 1916, dedicando-se à matéria da adoção, mas silenciando-se quanto à adoção do nascituro.

Mesmo com a vigência do Código Civil de 2002, o silêncio em relação à adoção do nascituro foi mantido. Entretanto, em 03 de agosto de 2009, entrou em vigência a Lei 12.010, alterando alguns artigos do Código Civil e do Estatuto da Criança e do Adolescente que regulamentavam a matéria da adoção. Neste sentido, nos dias atuais prevalece o entendimento de que o Estatuto da Criança e do Adolescente é o dispositivo que rege a matéria da adoção referente ao nascituro.

Com isso, a nova lei de adoção (12.010/2009) deu outra disposição aos parágrafos $4^{\circ}$ e $5^{\circ}$, do art. $8^{\circ}$ e ao parágrafo único, do art. 13, do Estatuto da Criança e do Adolescente:

\footnotetext{
Art. $8^{\circ}$ - É assegurado à gestante, através do Sistema Único de Saúde, o atendimento pré e perinatal.

[...]

$\S 4^{\circ}$. Incumbe ao poder público proporcionar assistência psicológica à gestante e à mãe, no período pré e pós-natal, inclusive como forma de prevenir ou minorar as consequências do estado puerperal.

$\S 5^{\circ}$. A assistência referida no $\S 4^{\circ}$ deste artigo deverá também ser prestada a gestantes ou mães que manifestem interesse em entregar seus filhos para adoção.

[...]

Art. 13. [...]

Parágrafo único. As gestantes ou mães que manifestem interesse em entregar seus filhos para adoção serão obrigatoriamente encaminhadas à Justiça da Infância e da juventude. ${ }^{244}$
}

\footnotetext{
${ }^{242}$ SEMIÃO, Sérgio Abdalla. Os direitos do nascituro: aspectos cíveis, criminais e do biodireito. - 2. ed. ver. atual. e ampl. - Belo Horizonte: Del Rey, 2000, p. 81.

${ }^{243}$ O artigo 372 do Código Civil de 1916 prescrevia que: "Não se pode adotar sem o consentimento do adotado ou de seu representante legal se for incapaz ou nascituro”. Disponível em: http://www.dji.com.br/codigos/1916 lei_003071_cc/cc0368a0378.htm. Acessado em: 22 de janeiro de 2014.

${ }^{244}$ BRASIL. Código Civil e Constituição Federal. Obra coletiva de autoria da editora Saraiva com a colaboração de Antônio Luiz de Toledo Pinto, Márcia Cristina Vaz dos Santos Windt e Lívia Céspedes. - 16. ed. - São Paulo: Saraiva, 2010, p. 415-416.
} 
É exatamente o que ocorreu no julgado retirado do Tribunal de Justiça de Santa Catarina:

\begin{abstract}
Ementa: ADOÇÃO. INSURGÊNCIA CONTRA ATO JUDICIAL. ALEGAÇÃO DE VÍCIO DO CONSENTIMENTO DA MANIFESTAÇÃO DE ENTREGAR A CRIANÇA AO CONSELHO TUTELAR. IMPROCEDÊNCIA. GENITORA QUE, ANTES DE DAR À LUZ, JÁ DEMONSTRAVA VONTADE NESSE SENTIDO. POSTERIOR ARREPENDIMENTO. DESCABIMENTO, POR SER A ADOÇÃO MEDIDA EXCEPCIONAL E IRREVOGÁVEL. DENEGAÇÃO DA ORDEM QUE SE IMPÕE. Estando ciente a grávida acerca das consequências que o ato da entrega do nascituro ao Conselho Tutelar lhe acarretaria, devidamente orientada também por psicólogo judicial e por assistente social, e manifestando a sua intenção antes mesmo do nascimento, irretocável a sentença que decretou a adoção da criança a casal habilitado no competente cadastro. (TJSC - Mandado de Segurança ${ }^{\circ}$ 2012.061854-3, Rel. Des. Jaime Luiz Vicari, julgado em 07/02/2013). ${ }^{245}$
\end{abstract}

A genitora manifestou seu interesse em doar o nascituro para adoção, tendo passado por todos os requisitos junto ao Conselho Tutelar, inclusive acompanhamento psicológico. Após o nascimento da criança tentou revogar a adoção, não logrando êxito, conforme demonstrado no julgado acima.

Portanto, demonstra-se que o nascituro pode ser adotado, avivando outra vez a capacidade jurídica deste ente, reafirmando sua condição de sujeito de direito no ordenamento jurídico.

\title{
4.5 \\ Direito a alimentos
}

O ser humano não consegue sobreviver sem os alimentos, por isso é amparado pelo ordenamento jurídico pátrio não de uma forma restrita, mas em tudo aquilo que é necessário para a subsistência da pessoa, englobando saúde, educação, vestuário, lazer, etc.

No ordenamento jurídico brasileiro nota-se que a obrigação alimentar é fundada no parentesco, mas também decorre da lei, sendo recíproca entre ascendentes, descendentes e colaterais de $2^{\circ}$ grau, tendo por fundamento o princípio da solidariedade familiar. Entretanto, até a vigência da Lei no 11.804 de

\footnotetext{
${ }^{245}$ Disponível em: http://app.tjsc.jus.br/jurisprudencia/busca.do\#resultado_ancora. Acessado em: 22 de janeiro de 2014.
} 
05 de novembro de 2008, que regulamenta os alimentos gravídicos, existia uma lacuna referente aos alimentos do nascituro.

O dever de amparar os que não podem prover a própria subsistência é do Estado, este, por sua vez, transfere às pessoas que pertencem ao mesmo grupo familiar tal dever. A Constituição de 1988 deixa claro essa responsabilidade em seus arts.227 e 229, in verbis:

Art. 227. É dever da família, da sociedade e do Estado assegurar à criança, ao adolescente e ao jovem, com absoluta prioridade, o direito à vida, à saúde, à alimentação, à educação, ao lazer, à profissionalização, à cultura, à dignidade, ao respeito, à liberdade e à convivência familiar e comunitária, além de colocá-los a salvo de toda forma de negligência, discriminação, exploração e violência, crueldade e opressão.

[...]

Art. 229. Os pais têm o dever de assistir, criar e educar os filhos menores, e os filhos maiores têm o dever de ajudar e amparar os pais na velhice, carência ou enfermidade. ${ }^{246}$

Percebe-se nos artigos acima que o ordenamento jurídico brasileiro preocupa-se com a entidade familiar, garantindo a subsistência de parte da família.

Neste sentido, Caio Mario da Silva Pereira afirma que é imposto ”aos parentes do necessitado, ou pessoa a ele ligada por um elo civil, o dever de proporcionar-lhe as condições mínimas de sobrevivência, não como favor ou generosidade, mas como obrigação judicialmente exigível”. 247

E ainda salienta Carlos Roberto Gonçalves que "entre pais e filhos menores, cônjuges e companheiros não existe propriamente obrigação alimentar, mas um dever familiar, respectivamente de sustento e mútua assistência”. ${ }^{248}$

Diante disso, o referido dever foi imposto às pessoas mais próximas do necessitado, em virtude de vínculo afetivo, em uma relação de natureza familiar.

Portanto, a obrigação alimentar, além de um dever moral de cuidado com a pessoa, tornou-se uma obrigação jurídica de prestar assistência a quem necessita.

Os artigos 1.695 e 1.694, $\S 1^{\circ}$ do Código Civil dispõem que:

\footnotetext{
${ }^{246}$ BRASIL. Código Civil e Constituição Federal. Obra coletiva de autoria da editora Saraiva com a colaboração de Antônio Luiz de Toledo Pinto, Márcia Cristina Vaz dos Santos Windt e Lívia Céspedes. - 16. ed. - São Paulo: Saraiva, 2010, p. 132.

${ }^{247}$ PEREIRA, Caio Mario da Silva. Instituições de Direito Civil, vol. V. Direito de Família. Rio de Janeiro: Forense, 2006, p. 495.

${ }^{248}$ GONÇALVES, Carlos Roberto. Direito civil brasileiro, volume 6: direito de família. - $9^{\circ}$ ed. São Paulo: Saraiva, 2012, p. 507.
} 
Art. 1695. São devidos os alimentos quando quem os pretende não tem bens suficientes, nem pode prover, pelo seu trabalho, à própria mantença, e aquele, de quem se reclamam, pode fornecê-los, sem desfalque do necessário ao seu sustento.

Art. 1.694. Podem os parentes, os cônjuges ou companheiros pedir uns aos outros os alimentos de que necessitam para viver de modo compatível com a sua condição social, inclusive para atender às necessidades de sua educação.

$\S 1^{\circ}$ Os alimentos devem ser fixados na proporção das necessidades do reclamante e dos recursos da pessoa obrigada.

Assim sendo, os alimentos só poderão ser reclamados pelo parente que se encontre, por algum motivo, impossibilitado de provê-los. Mas nem todas as pessoas do grupo familiar são obrigadas a suprir alimentos, somente os ascendentes, descendentes maiores e capazes, irmãos e o ex-cônjuge, sendo que este, apesar de não ser parente, tem o dever legal de assistência em razão do vínculo matrimonial.

No que tange à necessidade do alimentado, sabe-se que os alimentos são devidos quando não se tem bens suficientes e nem se pode prover a própria mantença pelo seu trabalho.

Quanto à possibilidade do alimentante, a obrigação de alimentar só atinge quem tem possibilidade de prestar alimentos, não atingindo, portanto, quem possui somente o necessário à sua subsistência, pois não pode causar prejuízo ao seu próprio sustento, e não seria justo fazê-lo abrir mão de sua mantença. Daí a necessidade de analisar a possibilidade do alimentante em prover financeiramente o alimentado, pois aquele será obrigado a ajudar caso não venha a sacrificar-se para tanto.

Nessas condições deve o alimentante contribuir somente com aquilo que estiver dentro dos limites de sua condição.

Assim, os alimentos se destinam a mantença da pessoa que deles necessita e constitui um direito pessoal, só podendo ser exercido por seu titular, tendo, portanto, seu caráter personalíssimo.

A Lei 11.804 de 05 de Novembro de 2008, também chamada de Lei de Alimentos Gravídicos, regulamenta ao nascituro o direito de receber alimentos. Alimentos estes que são destinados a resguardar o devido desenvolvimento e nascimento do nascituro. Com caráter protecionista, a referida lei não visa somente resguardar os direitos do nascituro, como também da gestante. 
O assunto referente ao reconhecimento de alimentos ao nascituro suscita muita controvérsia mesmo após a vigência da lei 11.804/2008. Alguns doutrinadores, como Arnold Wald, defendem que não se deve conceder alimentos ao nascituro. ${ }^{249}$

Contudo, outros, como Pontes de Miranda, Silmara Juny de Abreu Chinelato e Almeida reconhecem o direito do nascituro à alimentação. 250

Silmara Chinelato afirma que:

Em nosso modo de ver, ao nascituro - inclusive ao adotado - são devidos, como direito próprio, alimentos em sentido lato - alimentos civis - para que possa nutrir-se e desenvolver-se com normalidade, objetivando o nascimento com vida. Incluem-se nos alimentos a adequada assistência médico-cirúrgica pré-natal, em sua inteireza, que abrange as técnicas especiais (transfusão de sangue, em caso de eritroblastose fetal, amniocentese, ultra-sonografia) e cirurgias realizadas em fetos, cada vez mais frequentes, alcançando, ainda, as despesas com o parto. ${ }^{251}$

Nota-se que a afirmativa de Chinelato acerca do direito a alimentos do nascituro é bem anterior ao início da vigência da lei 11.804/2008, já entendendo pelo reconhecimento dos alimentos àquele, o que torna inconcebível o entendimento após a vigência da referida lei de que não se deve conceber alimentos ao nascituro.

Neste sentido, Maria Berenice Dias discorre sobre a relevância da lei 11.804/2008 para o reconhecimento dos alimentos ao nascituro.

Ainda que inquestionável a responsabilidade parental desde a concepção, o silêncio do legislador sempre gerou dificuldade para a concessão de alimentos ao nascituro. Raras vezes a justiça teve a oportunidade de reconhecer a obrigação alimentar antes do nascimento, pois a lei de alimentos exige prova do parentesco ou da obrigação. O máximo que se chegou foi, nas ações investigatórias de paternidade, deferir alimentos provisórios quando há indícios de vinculo parental ou após o resultado positivo do teste de DNA. Graças à Súmula do STJ ${ }^{252}$, também a resistência em se submeter ao exame passou a servir de fundamento para antecipação da tutela alimentar.

\footnotetext{
${ }^{249}$ ZAINAGHI, Maria Cristina. Os meios de defesa dos direitos do nascituro. - São Paulo: LTr, 2007, p. 89-90.

${ }^{250}$ Ibid.

${ }^{251}$ ALMEIDA, Silmara J. A. Chinelato e. Tutela civil do nascituro. - São Paulo: Saraiva, 2000, p. 243.

${ }^{252}$ Súmula 301: "Em ação investigatória, a recusa do suposto pai a submeter-se ao exame de DNA induz a presunção juris tantum de paternidade. BRASIL. Código Civil e Constituição Federal. Obra coletiva de autoria da editora Saraiva com a colaboração de Antônio Luiz de Toledo Pinto, Márcia Cristina Vaz dos Santos Windt e Lívia Céspedes. - 16. ed. - São Paulo: Saraiva, 2010, p. 724.
} 
Assim, em muito boa hora é preenchida injustificável lacuna. ${ }^{253}$

Além de a doutrina reconhecer o direito do nascituro aos alimentos, a jurisprudência também vem concorrendo com essa posição.

EMENTA: AGRAVO DE INSTRUMENTO - ALIMENTOS GRAVÍDICOS INDÍCIOS DE PATERNIDADE - FIXAÇÃO COM OBSERVÂNCIA AO BINÔMIO NECESSIDADE/POSSIBILIDADE - AUSÊNCIA DE PROVA DA INCAPACIDADE FINANCEIRA - RECURSO NÃO PROVIDO. - Estando presentes os indícios de paternidade conforme o disposto no artigo $6^{\circ}$ da Lei ${ }^{\circ}$ 11.804/08, há a obrigação de prestar alimentos gravídicos ao nascituro, a fim de cobrir despesas adicionais do período de gravidez e que sejam dela decorrentes, da concepção ao parto. Para a fixação deve-se observar o binômio necessidade/possibilidade. Contudo, não tendo o agravante comprovado sua incapacidade financeira em arcar com os alimentos provisórios fixados, a decisão proferida em primeira instância deverá ser mantida. (TJMG - Agravo de instrumento $\mathrm{n}^{\mathrm{o}}$ 1.0024.11.059531-1/001 0348261-03.2011.8.13.000, Rel. Des. Hilda Teixeira da Costa, julgado em 05/06/2012). ${ }^{254}$

Assim, nota-se que a Lei 11.804/2008 veio a reconhecer direitos personalíssimos ao nascituro, como o direito à vida, à dignidade e ao desenvolvimento saudável, figurando este ente como detentor do direito à alimentação, o que o torna capaz de direitos e deveres na ordem civil.

\section{6 \\ Direito a Reparação por Dano Moral}

Conceituar responsabilidade civil não é tarefa fácil, tendo em vista as inúmeras e inusitadas relações sociais com que o direito tem se deparado nos dias atuais.

Dessa forma, Sérgio Cavalieri Filho, aduz ser a responsabilidade civil um “dever jurídico que surge para recompor o dano decorrente da violação de um direito", tendo como sujeito passivo, aquele que deu causa - direta ou

\footnotetext{
${ }^{253}$ Disponível em http://www.mariaberenice.com.br/uploads/27 - alimentos grav\%EDdicos.pdf. Acessado em: 23 de janeiro de 2014.

${ }^{254}$ Disponível em:

http://www5.tjmg.jus.br/jurisprudencia/pesquisaPalavrasEspelhoAcordao.do?\&numeroRegistro=3 \&totalLinhas=14\&paginaNumero=3\&linhasPorPagina=1\&palavras=alimentos\%20nascituro\&pes uisarPor=ementa\&pesquisaTesauro=true\&orderByData=1\&pesquisaPalavras=Pesquisar\&.

Acessado em: 23 de janeiro de 2014.
} 
indiretamente - ao dano e como sujeito ativo, aquele que efetivamente sofreu o dano, seja este moral ou patrimonial. ${ }^{255}$

Nota-se, na referida definição, que a responsabilidade civil tem como fator determinante a ocorrência do dano, ou seja, da conduta do agente deve gerar um prejuízo à pessoa ofendida, seja patrimonial ou extrapatrimonial.

Rui Stoco afirma que no âmbito civil, o dever de reparar assegura que o lesado tenha o seu patrimônio - material ou moral - reconstituído ao statu quo ante. ${ }^{256}$ Já os doutrinadores Pablo Stolze Gagliano e Rodolfo Pamplona Filho afirmam que a responsabilidade civil "pressupõe a atividade danosa de alguém que, atuando a priori ilicitamente, viola uma norma jurídica preexistente, subordinando-se, dessa forma, às conseqüências do seu ato (obrigação de reparar)". 257

Percebe-se que a responsabilidade civil, contribui consideravelmente para o equilíbrio das relações sociais, tendo por objetivo ressarcir a vítima da forma mais integral possível e evitar a propagação de condutas danosas, utilizando-se para isso das normas previstas em lei.

Neste norte, detecta-se que o instituto da responsabilidade civil tem por fim restabelecer a busca da harmonia e do equilíbrio violados pelo dano injusto.

Com a promulgação da Constituição Federal de 1988 o direito brasileiro enraizou e disseminou a aplicabilidade do instituto da responsabilidade civil de forma definitiva, nos dizeres de Rui Stoco, foi a partir dela que a responsabilidade civil alcançou espaços de aplicabilidade insuspeitáveis, contribuindo de forma notável nas relações humanas, acautelando e resguardando seus bens patrimoniais e morais de maneira acentuada e forte. ${ }^{258}$

Com o advento da Constituição Federal de 1988, a responsabilidade civil ganhou status constitucionais, uma vez que o artigo $5^{\circ}$, incisos $\mathrm{V}$ e $\mathrm{X}$, estabelece o dever de indenizar, assim dispondo:

\footnotetext{
${ }^{255}$ CAVALIERI FILHO, Sérgio. Programa de responsabilidade civil. $7^{\mathrm{a}}$ ed. rev. e atual. São Paulo: Atlas, 2007, p. 2.

${ }^{256}$ STOCO, Rui. Tratado de Responsabilidade Civil. Doutrina e Jurisprudência. $7^{\mathrm{a}}$ ed. São Paulo: Revista dos Tribunais, 2007, p. 114.

257 GAGLiANO, Pablo Stolze; FILHO Rodolfo Pamplona. Novo Curso de Direito Civil. Responsabilidade Civil. 9a ed. São Paulo, 2011. Vol III, p. 51.

${ }^{258}$ STOCO, Rui. Tratado de Responsabilidade Civil. Doutrina e Jurisprudência. $7^{\text {a }}$ ed. São Paulo: Revista dos Tribunais, 2007, p. 155.
} 
Art. $5^{\circ}$ Todos são iguais perante a lei, sem distinção de qualquer natureza, garantindo-se aos brasileiros e aos estrangeiros residentes no país a inviolabilidade do direito à vida, à liberdade, à igualdade, à segurança e à propriedade, nos termos seguintes:

$[\ldots]$

V - é assegurado o direito de resposta, proporcional ao agravo, além da indenização por dano material, moral ou à imagem;

$[\ldots]$

X - são invioláveis a intimidade, a vida privada, a honra e a imagem das pessoas, assegurado o direito a indenização pelo dano material ou moral decorrente de sua violação;

$[\ldots]^{259}$

A responsabilidade civil em sua essência é um instituto uno, indivisível, em que aquele que deu causa ao dano está juridicamente obrigado a repará-lo. Ocorre que em função de peculiaridades didáticas, faz-se necessário estabelecer uma classificação sistemática sobre esse instituto, tendo por base a questão da culpa. $^{260}$

Dessa forma, se faz necessário expor as teorias subjetiva e objetiva por serem as duas espécies que norteiam toda a aplicabilidade do instituto da responsabilidade civil no direito brasileiro.

A noção básica da responsabilidade civil subjetiva reside no fato de que cada qual responde pela própria culpa, "por se caracterizar em fato constitutivo do direito à pretensão reparatória, caberá ao autor, sempre, o ônus da prova de tal culpa do réu.” 261

Discorrendo sobre o tema, Carlos Roberto Gonçalves “diz ser subjetiva a responsabilidade quando se esteia na ideia de culpa”, ainda segundo ele "a prova da culpa do agente passa a ser pressuposto necessário do dano indenizável”. ${ }^{262}$ Assim, a responsabilidade do causador do dano somente se configura se agiu com dolo ou culpa ${ }^{263}$.

\footnotetext{
${ }^{259}$ BRASIL. Código Civil e Constituição Federal. Obra coletiva de autoria da editora Saraiva com a colaboração de Antônio Luiz de Toledo Pinto, Márcia Cristina Vaz dos Santos Windt e Lívia Céspedes. - 16. ed. - São Paulo: Saraiva, 2010, p. 18.

${ }^{260}$ GAgLiAnO, Pablo Stolze; FILHO Rodolfo Pamplona. Novo Curso de Direito Civil. Responsabilidade Civil. 9a ed. São Paulo, 2011. Vol III, p. 54.

${ }^{261}$ GAGLIANO, Pablo Stolze; FILHO Rodolfo Pamplona. Novo Curso de Direito Civil. Responsabilidade Civil. $9^{\text {a }}$ ed. São Paulo, 2011. Vol III, p. 54.

262 GONÇALVES, Carlos Roberto. Direito civil brasileiro. $3^{\mathrm{a}}$ ed. São Paulo: Saraiva, 2009. Vol. IV, p. 30.

${ }^{263}$ Culpa, em sentido amplo - culpa e dolo - compreende toda espécie de comportamento contrário ao Direito, seja intencional ou não. Tanto no dolo como na culpa há conduta voluntária do agente. Só que no dolo a conduta se manifesta ilícita desde a origem, pois é dotada de desvalor. Já na culpa a conduta nasce lícita, mas que pela falta de cuidado se torna ilícita. Em suma, no dolo o agente quer a ação e o resultado, ao passo que na culpa ele só quer a ação, vindo a atingir o
} 
A doutrina estabelece três pressupostos necessários para a configuração da responsabilidade civil subjetiva: a conduta, o nexo causal e o dano. A conduta pode ser definida como "o comportamento humano voluntário que se exterioriza através de uma ação ou omissão”. ${ }^{264} \mathrm{O}$ nexo causal, em suma, é um elemento referencial entre a conduta e o resultado. É através dele que se conclui quem foi o causador do dano. ${ }^{265}$ Por derradeiro, o dano é conceituado como sendo a subtração ou diminuição de um bem jurídico, quer trate-se de um bem patrimonial, quer trate-se de um bem extrapatrimonial. ${ }^{266}$

As inovações tecnológicas, as novas formas de a sociedade se relacionar, seja economicamente, religiosamente, politicamente etc, fizeram com que a responsabilidade civil passasse a abranger os mais diversos danos oriundos dessas relações, com fulcro no risco nelas existentes.

O entendimento de que não poderia haver responsabilidade sem culpa está hoje superado, uma vez que a multiplicação das oportunidades e das causas de danos evidenciou que a responsabilidade subjetiva mostrou-se insuficiente para cobrir todos os casos de reparação. ${ }^{267}$ Ademais, nem sempre o lesado consegue provar o nexo causal entre a conduta e o dano, seja por diferenças econômicas ou mesmo por peculiaridades do caso concreto.

Sergio Savi, ao discorrer sobre a responsabilidade civil objetiva, explicita que, a partir de meados do século XX, a vítima passou a desempenhar cada vez mais a função de protagonista da relação jurídica instaurada com o evento danoso, de modo que, ao contrário do que acontecia em grande número de situações, em que conseguia obter a indenização pelos danos sofridos, unicamente em virtude de conseguir comprovar o nexo causal entre o dano sofrido e a conduta do agente. ${ }^{268}$

Ainda segundo o autor, surgia um novo fundamento para a responsabilização. Da indispensável prova da culpa, passou-se a admitir a

resultado por desvio acidental de conduta de falta de cuidado. CAVALIERI FILHO, Sérgio. Programa de responsabilidade civil. $7^{\text {a }}$ ed. São Paulo: Atlas, 2007, p. 31.

${ }^{264}$ CAVALIERI FILHO, Sérgio. Programa de responsabilidade civil. $7^{\mathrm{a}}$ ed. rev. e atual. São Paulo: Atlas, 2007,CAVALIERI FILHO, 2007, p. 19.

${ }^{265}$ CAVALIERI FILHO, Sérgio. Programa de responsabilidade civil. $7^{\mathrm{a}}$ ed. rev. e atual. São Paulo: Atlas, 2007, p. 46.

${ }^{266}$ CAVALIERI FILHO, Sérgio. Programa de responsabilidade civil. $7^{\mathrm{a}}$ ed. rev. e atual. São Paulo: Atlas, 2007, p. 71.

${ }^{267}$ STOCO, Rui. Tratado de Responsabilidade Civil. Doutrina e Jurisprudência. $7^{\text {a }}$ ed. São Paulo: Revista dos Tribunais, 2007, p. 155.

${ }^{268}$ SAVI, Sérgio. Responsabilidade civil por perda de uma chance. $3^{\text {a }}$ ed. São Paulo: Atlas, 2012, p. 114-115. 
responsabilidade daqueles que causassem danos simplesmente em razão do exercício de suas atividades. Ou seja, a teoria da responsabilidade objetiva passou a fundamentar no risco, a responsabilização dos causadores de danos, sem a necessidade de se aferir o elemento psicológico (culpa) destes. ${ }^{269}$

Como observa Carlos Roberto Gonçalves, essa teoria tem como “postulado que todo dano é indenizável, e deve ser reparado por quem a ele se liga por um nexo de causalidade, independentemente de culpa”. ${ }^{270}$

A responsabilidade civil objetiva adquiriu espaço considerável de aplicabilidade, no direito brasileiro, por meio do artigo 927, parágrafo único, do Código Civil de 2002, que assim dispõe, in verbis:

Art. 927. [...]

Parágrafo único. Haverá obrigação de reparar o dano, independentemente de culpa, nos casos especificados em lei, ou quando a atividade normalmente desenvolvida pelo autor do dano implicar, por sua natureza, risco para os direitos de outrem.

Nesse sentido, Rui Stoco observa:

O Código Civil de 2002, embora tenha adotado e mantido a culpa como pressuposto da responsabilidade civil, ou seja, exigindo que a conduta tenha um qualificativo ligado ao elemento subjetivo ou interno da pessoa, de modo que há de projetar-se em direção a um resultado querido ou assumido, excepcionou esse principio para, como exceção, admitir a responsabilidade independentemente de culpa (objetiva) quando a atividade desenvolvida pelo autor do dano implicar risco para os direitos de outrem.

Deu-se notável importância às atividades de risco, seja ele criado ou inerente à própria atividade, ou esteja ligado a coisas inanimadas ou a animais. ${ }^{271}$

É importante ressaltar que a responsabilidade civil objetiva encontra rejeição ainda nos dias de hoje, mas as criticas não procedem, pois conforme assevera Sérgio Cavalieri Filho, não basta risco para gerar a obrigação de indenizar, a responsabilidade surge quando a atividade gera dano, há violação de um dever jurídico, qual seja, o dever de segurança. ${ }^{272}$

O direito brasileiro, por intermédio do artigo 186, combinado com o artigo 927 do Código Civil, dispõe que o dever de reparar está vinculado à ocorrência de

\footnotetext{
${ }^{269}$ Ibid.

${ }^{270}$ GONÇALVES, Carlos Roberto. Direito civil brasileiro. $3^{\mathrm{a}}$ ed. São Paulo: Saraiva, 2009. Vol. IV, p. 30.

${ }^{271}$ STOCO, Rui. Tratado de Responsabilidade Civil. Doutrina e Jurisprudência. $7^{\text {a }}$ ed. São Paulo: Revista dos Tribunais, 2007, p. 129.

${ }^{272}$ CAVALIERI FILHO, Sérgio. Programa de responsabilidade civil. $7^{\mathrm{a}}$ ed. rev. e atual. São Paulo: Atlas, 2007, p. 131.
} 
dano, não havendo dano, não há possibilidade de se imputar a responsabilidade civil.

Depreende-se que a doutrina é unânime em admitir o dano como pressuposto maior para a caracterização do dever de reparar. Mesmo com a atual flexibilização jurisprudencial em admitir novas possibilidades indenizatórias, como o reconhecimento do dano moral ao nascituro, constata-se que o dano prevalece como requisito basilar para a imputação da responsabilidade civil.

Nesse sentido, Anderson Schreiber, afirma:

[...] esta flexibilização indica uma alteração gradativa e eminentemente jurisprudencial na estrutura da responsabilidade civil, a refletir a valorização de sua função compensatória e a crescente necessidade de assistir a vítima em uma realidade social marcada pela insuficiência das políticas públicas na administração e reparação dos danos. Neste contexto, os pressupostos da responsabilidade civil relacionados à imputação do dever de indenizar (culpa e nexo causal), perdem relevância em face de uma certa ascensão daquele elemento que consiste, a um só tempo, no objeto e ratio da reparação: o dano. ${ }^{273}$

Visto que a imputação da responsabilidade civil está inteiramente vinculada à ocorrência do dano, deve-se analisá-lo de forma distinta, assim como observa Carlos Roberto Gonçalves, “é possível distinguir, no campo dos danos, a categoria dos danos patrimoniais (ou materiais), de um lado, dos chamados danos extrapatrimoniais (ou morais) de outro”. ${ }^{274}$ Contudo, por conveniência do que se pretende analisar na presente pesquisa, será analisado apenas o dano extrapatrimonial ou moral.

O que é dano moral? A conceituação envolve tamanha discussão que em muitos casos dá ensejo ao dever de indenizar e em outros casos a negativa no dever de indenizar.

Dentre as correntes adotadas, segue-se o entendimento de Maria Celina Bodin de Moraes, que adota a metodologia civil- constitucional para definir dano moral, entendendo que o legislador estabeleceu constitucionalmente a proteção à

\footnotetext{
273 SCHREIBER, Anderson. Novos paradigmas da responsabilidade civil: da erosão dos filtros da reparação à diluição dos danos. - 5. ed. - São Paulo: Atlas, 2013, p. 83.

${ }^{274}$ GONÇALVES, Carlos Roberto. Direito civil brasileiro. $3^{\mathrm{a}}$ ed. São Paulo: Saraiva, 2009. Vol. IV, p. 339.
} 
pessoa, a tutela da pessoa humana, que tem por fim proteger, acima de tudo, a dignidade da pessoa humana. ${ }^{275}$

Maria Celina afirma que:

[...] o "dano moral, à luz da Constituição vigente, nada mais é do que violação do direito à dignidade” ${ }^{, 276}$. Se não se está de acordo, todavia, com a criação de um “direito subjetivo à dignidade", como foi sugerido, é efetivamente o princípio da dignidade humana, princípio fundante de nosso Estado democrático de Direito, que institui e encima, como foi visto, a cláusula geral de tutela da personalidade humana, segundo a qual as situações jurídicas subjetivas não - patrimoniais merecem proteção especial no ordenamento nacional, seja através de prevenção, seja mediante reparação, a mais ampla possível, dos danos a elas causados. ${ }^{277}$

\section{A autora acrescenta ainda que:}

Ao optar por fazer decorrer o dano moral dos sentimentos de dor e humilhação, das sensações de constrangimento ou vexame, teve a jurisprudência acertada intuição acerca de sua real natureza jurídica. Normalmente, o que nos humilha, ofende, constrange, o que nos magoa profundamente, é justamente o que fere a nossa dignidade. $\mathrm{O}$ dano moral tem como causa a injusta violação a uma situação jurídica subjetiva extrapatrimonial, protegida pelo ordenamento jurídico através da cláusula geral de tutela da personalidade que foi instituída e tem sua fonte na Constituição Federal, em particular e diretamente decorrente do princípio (fundante) da dignidade da pessoa humana (também identificado com o princípio geral de respeito à dignidade). ${ }^{278}$

A possibilidade do reconhecimento de dano moral à figura do nascituro é assunto muito discutido nos dias atuais, pois para que exista tal possibilidade é necessário reconhecer direitos personalíssimos a este ente.

No entanto, conforme já afirmado, o ordenamento jurídico pátrio e a jurisprudência mais atualizada vêm reconhecendo direitos existenciais ao nascituro, o que o torna um sujeito de direitos sem personalidade, mas detentor de uma expectativa de adquiri-la.

Portanto, mesmo o nascituro não detendo personalidade jurídica, ele titulariza direitos e obrigações na órbita jurídica, pois o ordenamento e jurisprudência o reconhecem como se pessoa fosse, devendo ser reconhecido

\footnotetext{
${ }^{275}$ MORAES, Maria Celina Bodin de. Danos à pessoa humana: uma leitura civil-constitucional dos danos morais. - Rio de Janeiro: Renovar, 2009.

${ }^{276}$ Neste sentido, segundo a autora manifestou o doutrinador Sérgio Cavalieri Filho e o Desembargador A. de Assis.

${ }^{277}$ MORAES, Maria Celina Bodin de. Danos à pessoa humana: uma leitura civil-constitucional dos danos morais. - Rio de Janeiro: Renovar, 2009, p. 131-132.

${ }^{278}$ Ibid., p. 132-133.
} 
como ente despersonalizado, não necessitando a ocorrência do nascimento com vida para adquirir direitos.

Assim, é possível a caracterização do dano moral ao nascituro, uma vez que desde a concepção ele é detentor do direito da personalidade e, consequentemente, de capacidade jurídica, sendo esta o principal pressuposto para a causalidade de dano moral a um ente.

Neste sentido, vale conferir decisão do Superior Tribunal de Justiça, que reconhece dano moral à figura do nascituro.

EMENTA: DIREITO CIVIL. DANOS MORAIS. MORTE. ATROPELAMENTO. COMPOSIÇÃO FÉRREA. AÇÃO AJUIZADA 23 ANOS APÓS EVENTO. PRESCRIÇÃ̃O INEXISTENTE. INFLUÊNCIA NA QUANTIFICAÇÃO DO QUANTUM. PRECEDENTES DA TURMA. NASCITURO. DIREITO AOS DANOS MORAIS. DOUTRINA. ATENUAÇÃO. FIXAÇÃO NESTA INSTÂNCIA. POSSIBILIDADE. RECURSO PARCIALMENTE PROVIDO.

I - Nos termos da orientação da Turma, o direito à indenização por dano moral não desaparece com o decurso de tempo (desde que não transcorrido o lapso prescricional), mas é fato a ser considerado na fixação do quantum.

II - O nascituro também tem direito aos danos morais pela morte do pai, mas a circunstância de não tê-lo conhecido em vida tem influência na fixação do quantum.

III - Recomenda-se que o valor do dano moral seja fixado desde logo, inclusive nesta instância, buscando dar solução definitiva ao caso e evitando inconvenientes e retardamento da solução jurisdicional. (STJ - Resp 399028/SP Recurso Especial 2001/0147319-0. Rel. Ministro Sálvio de Figueiredo Teixeira. Julgado 26/02/2002). ${ }^{279}$ (grifo nosso)

O Tribunal de Justiça de Minas Gerais também vem reconhecendo o direito a dano moral ao nascituro, conforme decisão a seguir:

EMENTA: RESPONSABILIDADE CIVIL - ACIDENTE DE TRÂNSITO MORTE DA VÍTIMA - SEGURADORA - RESPONSABILIDADE PELO VALOR CONTIDO NA APÓLICE. ILEGITIMIDADE DA PRIMEIRA AUTORA - INOCORRÊNCIA - DANO MORAL - NASCITURO - MORTE DO PAI - INDENIZAÇÃO DEVIDA - PENSÃO MENSAL - CONSIDERAÇÃO DOS MESMOS CRITÉRIOS FIXADOS PARA OS FILHOS LEGÍTIMOS DA VÍTIMA - DPVAT - COMPENSAÇÃO - IMPOSSIBILIDADE. 1- A seguradora responde perante o segurado pela indenização prevista na apólice. Assim, ainda que celebrado acordo em outro processo, envolvendo a mesma segurada e outras pessoas, relativo ao mesmo acidente, deve ela ser responsabilizada pelo valor remanescente, até o limite previsto no contrato. 2- O fato de a primeira autora não ser companheira ou esposa da vítima, não leva à ilegitimidade ativa quanto ao pleito de danos materiais e morais em razão do

${ }^{279}$ Disponível em: http://www.sti.jus.br/SCON/jurisprudencia/doc.jsp?livre=nascituro\&\&b=ACOR\&p=true\&t=\&l=1 0\&i=25. Acessado em: 28 de janeiro de 2014. 
acidente sofrido pelo pai de sua filha, mas, sim, à improcedência do pedido, mormente pela ausência de prova da dependência econômica desta em relação à vítima.

3- O dano moral constitui o prejuízo resultante da dor imputada à pessoa em razão de atos que, indevidamente, maculam seus sentimentos, provocando tristeza, mágoa ou atribulações na esfera interna pertinente à sensibilidade moral. 4- Embora o nascituro não tenha, por óbvio, conhecido ou convivido com o pai, antes do falecimento deste, não se pode negar que ele, assim como o filho de tenra idade, cujo pai teve sua vida ceifada precocemente, em razão de ato ilícito perpetrado por terceiro, é sujeito passivo de dano moral, na medida em que terá de conviver e de se conformar com a ausência do ente querido durante toda a sua vida. Afinal, o fato de a criança não ter conhecido o pai não minimiza ou elimina a dor e o abalo moral que sofrerá, por não tê-lo presente, notadamente nos primeiros anos de vida, acompanhando o seu crescimento, levando-o à escola e aos passeios e orientando-o, enfim, sendo privado do direito natural de ter o genitor presente em sua vida. 5- Em se tratando de indenização por danos materiais, em virtude de acidente de trânsito com vítima fatal, afigura-se justa a utilização dos mesmos critérios para a indenização concedida a todos os filhos, resultantes ou não da união conjugal. 6- Não se confundem a natureza da verba relativa à indenização de direito decorrente de sinistro e a oriunda do seguro obrigatório, DPVAT, por possuírem fundamentos e natureza distintos. Daí a impossibilidade de compensação. (TJMG - Apelação Cível $n^{0}$ 2.0000.00.457684-7/000. Rel. Desembargador Maurício Barros. Julgado em 08/06/2005). ${ }^{280}$ (grifo nosso)

Rodolfo Pamplona Filho e Ana Thereza Meirelles Araújo ao discorrerem sobre o dano moral ao nascituro reconhecem a possibilidade de reparação a dano sofrido por este ente, com fulcro no próprio ordenamento jurídico.

A polêmica em torno do início da personalidade humana ganha maiores contornos, quando se verifica que conferir possibilidade de reparação ao dano moral causado ao nascituro é direito corolário ao sistema de proteção já consubstanciado pelo ordenamento jurídico, independente da existência de sua personalidade. Ou seja, assegurar o direito à reparação de dano ao não nascido é corroborar a proteção dos direitos da personalidade que já lhes são assegurados de uma maneira geral, como por exemplo, o respeito à sua vida e à sua integridade física. ${ }^{281}$

Assim, conforme já afirmado, é possível a caracterização do dano moral causado ao nascituro, pois de acordo com a teoria dos entes despersonificados o

\footnotetext{
${ }^{280}$ Disponível em:

http://www5.tjmg.jus.br/jurisprudencia/pesquisaPalavrasEspelhoAcordao.do?palavras=danos+mor ais+nascituro\&numeroRegistro=1\&totalLinhas=1\&pesquisarPor=ementa\&pesquisaTesauro=true \&orderByData=1\&pesquisaPalavras=Pesquisar. Acessado em: 28 de janeiro de 2014.

${ }^{281}$ PAMPLONA FILHO, Rodolfo; ARAÚJO, Ana Thereza Meirelles. Tutela jurídica do nascituro à luz da Constituição Federal. Disponível em:

http://www.lex.com.br/doutrina_23883291_NASCITURO_TUTELA_JURIDICA_A_LUZ_DA_C ONSTITUICAO_FEDERAL.aspx. Acessado em: 28 de janeiro de 2014.
} 
mesmo possui, desde a concepção titularidade para figurar em relações jurídicas existenciais, atribuindo a ele direitos como se pessoa fosse.

\title{
4.7
}

\section{Outros direitos do nascituro}

É importante trazer à discussão, sobre os direitos tutelados ao nascituro, o fato de que não se pretende esgotar as situações em que este ente figura como sujeito de direitos, mas apenas apresentar algumas situações jurídicas existenciais em que o nascituro é titular.

Uma vez que não se pode esgotar as situações jurídicas existenciais aplicáveis ao nascituro, cabe neste tópico apenas apresentar algumas situações em que, mesmo não estando expressamente previstas em lei, deve-se reconhecê-los ao nascituro.

Silmara Chinelato ao discorrer sobre os direitos inerentes ao nascituro, além daqueles previstos em legislação, apresenta outros que devem ser atribuídos a este ente.

\begin{abstract}
Entre esses direitos salientamos, de modo não taxativo: direito de ser beneficiário de estipulação em favor de terceiro (art. 1.098 do CC) ${ }^{282}$, de ser beneficiário de seguro de vida (art. 1.474, c/c o art. 1.169, ambos do CC), direito a alimentos (arts. 396 a 405), direito à vida (art. 1.539) e direito à integridade física e à saúde (art. 1.538). ${ }^{283}$
\end{abstract}

Além dos direitos citados por Chinelato, existem diversos outros que são inerentes ao nascituro, mas que não foram abordados no trabalho, como o direito a ter nome, direito à imagem, recebimento de doações, direito à sucessão, dentre outros.

Portanto, ao deparar com casos que envolvem o nascituro, mesmo não havendo disposição legal que regulamente o assunto, não deve o julgador aplicar arbitrariamente sua decisão, mas analisar os casos utilizando a metodologia civilconstitucional. Ou seja, procurar aplicar os princípios e as regras constitucionais às relações em que é parte o nascituro, procurando superar a dicotomia públicoprivado e tentando indicar, à luz desses pressupostos metodológicos o

\footnotetext{
${ }^{282}$ Todos os artigos citados pela autora são do Código Civil de 1916.

${ }^{283}$ ALMEIDA, Silmara J. A. Chinelato e. Tutela civil do nascituro. - São Paulo: Saraiva, 2000, p. 239.
} 
reconhecimento do nascituro como sujeito de direitos despersonificado, detentor de dignidade.

A partir de uma interpretação civil-constitucionalizada da situação do nascituro, deve-se classificá-lo como sujeito despersonificado, porém ele deve ser tratado como se pessoa fosse, com dignidade e detentor de direitos da personalidade.

Portanto, interpretando o art. $2^{\circ}$ do Código Civil através da metodologia civil-constitucional, se reconhece não apenas uma característica patrimonial ao dispositivo, mas também um enfoque existencial que deve ser considerado, levando o nascituro a ser reconhecido como ente despersonificado. 


\section{5 \\ Conclusão}

A partir das ideias apresentadas no presente trabalho dissertativo, tendo como norte o princípio da dignidade da pessoa humana e a aplicação da hermenêutica civil-constitucional, foi possível identificar as seguintes conclusões:

1. Existem diversas situações jurídicas existenciais em que o nascituro é reconhecido como sujeito de direitos, o que gera enorme reflexão na doutrina e na jurisprudência brasileira acerca do momento em que se deve reconhecer personalidade à pessoa.

2. Para identificar qual a melhor teoria a ser aplicada à situação do nascituro, em um Direito Civil moderno, procurou-se inicialmente discutir sobre alguns conceitos de suma importância para o reconhecimento da natureza daquele ente, como o da dignidade da pessoa humana, dos direitos da personalidade, da personalidade jurídica e da capacidade.

3. A partir de uma melhor compreensão do princípio da dignidade da pessoa humana e dos direitos da personalidade, foram apresentadas algumas teorias clássicas e contemporâneas que procuram solucionar a discussão referente à natureza jurídica do nascituro.

4. Foram apresentadas diversas situações jurídicas em que o ordenamento jurídico reconhece o nascituro como sujeito de direitos, e que combinadas com uma interpretação civil-constitucional dada ao art. $2^{\circ}$ do Código Civil, identificase qual a melhor teoria a solucionar o problema deste ente.

5. O princípio da dignidade da pessoa humana identificado como cláusula geral dos direitos da personalidade é a base para o reconhecimento do nascituro como sujeito de direito de relações jurídicas existenciais, pois este princípio não deve ser reconhecido apenas no momento em que é violado, mas trata-se de um princípio inerente a qualquer pessoa, sem discriminação.

6. A partir do momento que é reconhecido ao nascituro direitos personalíssimos, como o direito à vida, à saúde, à integridade física, dentre outros, o ordenamento jurídico garante a proteção destes direitos, sempre com fundamento na salvaguarda do princípio da dignidade da pessoa humana. 
7. Os direitos da personalidade, que são considerados essenciais a todos os seres humanos e que resguardam a sua dignidade, são inerentes ao nascituro, uma vez que o próprio ordenamento jurídico brasileiro reconhece a ele esses direitos.

8. Neste sentido, entende-se que o nascituro é detentor de tutela a direitos da personalidade, mas não é detentor de personalidade jurídica que apenas é adquirida após o nascimento com vida. Assim, o nascituro não é pessoa, mas o ordenamento jurídico o reconhece como se pessoa fosse.

9. A doutrina clássica afirma que toda pessoa é detentora de personalidade jurídica e por isso é sujeito de direitos, e para estes autores somente são pessoas as pessoas naturais (seres humanos já nascidos), e as pessoas jurídicas (grupos de pessoas ou de bens a quem o direito atribui titularidade jurídica), atrelando a ideia de pessoa à personalidade. Portanto, a personalidade jurídica é a aptidão para que as pessoas sejam titulares de direitos e deveres na ordem jurídica.

10. A ideia de personalidade para alguns está atrelada à ideia de capacidade, ou seja, existe ainda o entendimento de que a capacidade nada mais é do que um atributo da personalidade. Nos dias atuais, não há mais que identificar a personalidade com a capacidade, uma vez que pode haver a capacidade sem que haja personalidade, como é para nós o caso do nascituro e de outros entes como a massa falida, o condomínio, a herança jacente e vacante, a sociedade de fato ou irregular, o espólio e os animais; ainda que não tenham personalidade, como prevê o ordenamento, são capazes de direitos e deveres, o que os classifica como entes despersonificados.

11. Nesta esteira, entende-se que a ideia de sujeito de direito não está mais necessariamente atrelada à personalidade jurídica, pois o ordenamento jurídico reconhece os entes despersonificados como sujeitos de direito, lhes conferindo o status de pessoa. Assim, o art. $2^{\circ}$ do Código Civil deve receber uma interpretação com fundamento na metodologia civil-constitucional em um caráter existencial. Ou seja, a norma, que até então era interpretada apenas com uma carga patrimonial, deve receber uma interpretação de cunho existencial.

12. Portanto, numa perspectiva civil-constitucional detecta-se que a personalidade jurídica não deve, necessariamente, estar ligada à ideia de aptidão para ser sujeito de direitos, e sim estar ligada à ideia de dignidade da pessoa humana reconhecendo uma vida digna a todas as pessoas. 
13. Contudo, mesmo o nascituro já tendo sido identificado como detentor de capacidade pelo ordenamento, existem algumas teorias que classificam este ente e trazem suas peculiaridades, quais sejam: a teoria natalista, a teoria da concepção e a teoria da concepção condicionada. São as três teorias tidas como as mais importantes acerca da natureza jurídica do nascituro, mas entendemos não serem as mais acertadas para a solução do problema proposto. Abordamos as teorias análogas, que por meio da análise de algumas circunstâncias que não são consideradas pelas teorias clássicas, procuramos solucionar o problema de uma maneira melhor, aplicando ao nascituro a teoria dos entes despersonificados.

14. Os adeptos da teoria natalista defendem que o nascituro não é considerado pessoa, uma vez que para adquirir personalidade jurídica é necessário o nascimento com vida. Isto é, o nascituro não é pessoa sendo apenas um ente que detém expectativa de direitos. Mas os defensores desta teoria acabam esbarrando em várias questões que a torna distante da realidade vivida atualmente, como, por exemplo, as novas técnicas de reprodução assistida e a proteção dos direitos do embrião, negando em alguns momentos os próprios direitos fundamentais inerentes ao nascituro, como o direito à vida, ao nome, aos alimentos dentre outros.

15. Os defensores da teoria da concepção ou concepcionista sustentam que o nascituro é pessoa, estando desde o momento de sua concepção com todos os seus direitos resguardados pelo ordenamento jurídico, e isto gera a aquisição da personalidade jurídica. Entretanto, assim como a teoria natalista, esta também tem suas fragilidades, como o descrito no próprio art. $2^{\circ}$ do Código Civil, ou seja, o ordenamento, diferentemente do que quer fazer crer os defensores desta teoria, de uma forma expressa declara o não reconhecimento da personalidade ao nascituro, o que acaba por fragilizar a tentativa de solucionar o problema do nascituro.

16. Já os adeptos da teoria condicionalista ou da personalidade condicional defendem que existe uma condição suspensiva para que o nascituro se torne pessoa, tratando este como uma pessoa condicional, que está submetida ao eventual nascimento com vida. Os condicionalistas defendem que a condição para que o nascituro seja sujeito de direito, isto é, tenha seus direitos legalmente protegidos, é a de que venha nascer com vida, o que caracteriza um forte apego patrimonial à teoria, não preocupando seus adeptos com o nascituro e sim com o 
patrimônio que ele poderá vir a adquirir, não sendo também a melhor solução para problema.

17. A teoria dos entes despersonificados, em consonância com a teoria natalista, reconhece não ser o nascituro detentor de personalidade jurídica, mas o classifica como sujeito de direitos, ou seja, mesmo não tendo personalidade ele é tratado pelo ordenamento jurídico como se fosse pessoa.

18. Assim, o que se identifica é que o ordenamento jurídico, em consonância com a doutrina e a jurisprudência pátrias, vem imputando aos chamados entes despersonificados - espólio, massa falida, condomínio, herança jacente e vacante, sociedade de fato ou irregular, animais e o nascituro - a qualidade de sujeito de direitos, reconhecendo a eles a capacidade jurídica, ainda que sejam desprovidos de personalidade jurídica.

19. Portanto, a teoria dos entes despersonificados reconhece o nascituro como um ente não personificado, partindo de uma interpretação civilconstitucional do art. $2^{\circ}$ do Código Civil, que prescreve ser o início da personalidade após o nascimento com vida, mas põe a salvo, desde a concepção, os direitos do nascituro.

20. A partir dessa interpretação civil-constitucional elencada no art. $2^{\circ}$ do Código Civil, o nascituro é reconhecido como titular de direitos personalíssimos como o direito à vida, direito a alimentos, direito ao dano moral, direito à filiação, direito à curatela, direito à adoção dentre outros, mas não o torna detentor de personalidade jurídica, resguardando a lei desde a concepção seus direitos.

21. Portanto, considerando que o nascituro tem seus direitos resguardados por lei, desde o momento da concepção, pode-se assumir que ele é um sujeito de direito na ordem jurídica, porém desprovido de personalidade civil. Em uma leitura clássica a personalidade civil seria um requisito imprescindível para figurar na relação jurídica e ser detentor de direitos ou obrigações. Daí, conclui-se que o nascituro é sujeito de direito despersonificado. Neste viés dialético, identifica-se que a existência de personalidade jurídica deixa de ser requisito para que o sujeito seja detentor de direitos e deveres, sendo necessário reconstruir ou ressignificar a ideia de personalidade jurídica e seus limites de extensão. 


\section{6 \\ Referências Bibliográficas}

ACKEL FILHO, Diomar. Direito dos Animais. São Paulo: Themis, 2001.

ALMEIDA, Silmara Juny de Abreu Chinelato e. Tutela Civil do Nascituro. São Paulo, 2000.

AMARAL, Francisco. Direito Civil: Introdução. $7^{\text {a }}$ ed. rev., atual. e aum., Rio de Janeiro: Renovar, 2008.

AZEVEDO, Antônio Junqueira de. Caracterização jurídica da dignidade da pessoa humana. Revista USP, São Paulo, ${ }^{0}$ 53, março/maio 2002, p. 90-101. www.usp.br/revistausp/53/09-junqueira.pdf. Acesso em: 11/07/2013.

AZEVEDO, Eder Marques. Da Desconstrução do Homo Sapiens à Consolidação dos Animais Não-humanos como Sujeitos de Direito: Uma questão de personalidade?. No prelo da Revista de Direito da Universidade do Estado do Rio de Janeiro - UERJ.

BARROSO, Luís Roberto. A dignidade da pessoa humana no direito constitucional contemporâneo: a construção de um conceito jurídico à luz da jurisprudência mundial; tradução Humberto Laport de Mello. - $1^{\mathrm{a}}$ reimpressão. - Belo Horizonte: Fórum, 2013.

BEVILÁQUA, Clóvis. Teoria geral do direito civil. Revista e Atualizada por Caio Mário da Silva Pereira. 2a edição. Rio de Janeiro: Editora Rio, 1980.

BITTAR, Carlos Alberto. Os direitos da personalidade. $7^{\text {a }}$ ed. Rio de Janeiro: Forense, 2008.

BORGES, Janice Silveira. Direito Civil: Atualidades III - princípios jurídicos no direito privado. Coordenadores: César Fiuza, Maria de Fátima Freire de Sá, Bruno Torquato de Oliveira Naves. Belo Horizonte: Del Rey, 2009.

BRASIL., Código Civil Brasileiro. São Paulo: Saraiva, 2011.

BRASIL, Constituição da República Federativa do Brasil. São Paulo: Saraiva, 2011.

BRASIL. Código Civil e Constituição Federal. Obra coletiva de autoria da editora Saraiva com a colaboração de Antônio Luiz de Toledo Pinto, Márcia Cristina Vaz dos Santos Windt e Lívia Céspedes. - 16. ed. - São Paulo: Saraiva, 2010. 
BRASIL. Lei $n^{0} \underline{9.605}$, de 12 de fevereiro de 1998. Dispõe sobre as sanções penais e administrativas derivadas de condutas e atividades lesivas ao meio ambiente, e dá outras providências. Disponível em: http://www.planalto.gov.br/ccivil_03/leis/L9605.htm. Acesso em: 06 de janeiro de 2014.

BRASIL. Lei $\mathbf{n}^{\circ} \mathbf{8 . 0 6 9}$ de 13 de julho de 1990. Que dispõe sobre o Estatuto da Criança e do Adolescente e dá outras providências. Disponível em: http://www.planalto.gov.br/ccivil_03/leis/18069.htm. Acesso em: 17 de janeiro de 2014.

CANTALI, Fernanda Borghetti. Direitos da personalidade: disponibilidade relativa, autonomia privada e dignidade humana. Porto Alegre: Livraria do Advogado, 2009.

CAVALIERI FILHO, Sérgio. Programa de responsabilidade civil. $7^{\mathrm{a}}$ ed. rev. e atual. São Paulo: Atlas, 2007, p. 2.

CHAVES, Benedita Inês Lopes. A tutela jurídica do nascituro. São Paulo: LTr, 2000.

COELHO, Fábio Ulhoa. Curso de Direito Civil: parte geral, volume 1. - 5a ed. - São Paulo: Saraiva, 2012.

CORTIANO JUNIOR, Erouths. Alguns apontamentos sobre os chamados direitos da personalidade. In: FACHIN, Luiz (org.), Repensando fundamentos do direito civil contemporâneo. Rio de Janeiro: Renovar, 1999.

CUNHA, Alexandre dos Santos. Dignidade de pessoa humana: o conceito fundamental do direito civil, in A reconstrução do direito privado. Org. Judith Martins-Costa, São Paulo: Revista dos Tribunais, 2002.

DANTAS, San Tiago. Clássicos da literatura jurídica. Programa de direito civil: parte geral. $4^{\mathrm{a}}$ tiragem. Editora Rio: Rio de Janeiro, 1979.

DE CUPIS, Adriano. Os direitos da personalidade. Campinas: Romana Jurídica, 2004.

DIAS, Maria Berenice. Manual de direito das famílias. 5. ed. São Paulo: RT, 2009.

DONEDA, Danilo. Os direitos da personalidade no novo código civil. In: TEPEDINO, Gustavo (org.). A parte geral do novo código civil: estudos na perspectiva civil-constitucional. 2 ed. Rio de Janeiro: Renovar, 2003.

FARIAS, ROSENVALD, Cristiano Chaves de, Nelson. Direito Civil: teoria geral. 9a ed., Rio de Janeiro: Lumen Juris, 2011. 
FERREIRA, Aurélio Buarque de Holanda. Novo dicionário Aurélio da língua portuguesa. - 3. ed. - Curitiba: Positivo, 2004.

FIÚZA, César. Direito civil: curso completo. 8. ed., rev., atual. e ampl. - Belo Horizonte: Del Rey, 2004.

FIUZA, Ricardo (Coordenador). Novo Código Civil comentado. 6. ed., $4^{\mathrm{a}}$ tiragem. São Paulo: Saraiva, 2008.

FRANÇA, Rubens Limongi. Instituições de direito civil. $3^{\text {a }}$ ed. atual. - São Paulo: Saraiva, 1994.

GAGLIANO, Pablo Stolze; FILHO Rodolfo Pamplona. Novo Curso de Direito Civil. Responsabilidade Civil. 9a ed. São Paulo, 2011.

GOMES, Orlando. Introdução ao direito civil. 13 ed. Rio de Janeiro: Forense, 1998.

GONÇALVES, Carlos Roberto. Direito civil brasileiro, volume 6: direito de família. $-9^{\circ}$ ed. - São Paulo: Saraiva, 2012.

2009. Vol. IV.

Carlos Roberto. Direito civil brasileiro. $3^{\mathrm{a}}$ ed. São Paulo: Saraiva,

HABERMAS, Jurgen. O conceito de dignidade humana e a utopia realista dos direitos humanos. Trad. Eduardo Mendonça e Letícia de Campos Velho Martel. Do original, enviado pelo autor a convite do Conselho Editorial da RDE: Das Konzept der Menschenwürde und die realistische Utopie der Menschenrechte (2010, korrigierte Fassung).

Jurgen. O futuro da natureza humana. Trad. Karina Jannini. São Paulo: Martins Fontes, 2004.

LOPES, Miguel Maria de Serpa. Curso de direito civil: introdução, parte geral e teoria dos negócios jurídicos, volume I. $-9^{\text {a }}$ ed. ver. e atual. pelo Prof. José Serpa de Santa Maria - Rio de Janeiro: Freitas Bastos, 2000.

LOURENÇO, Daniel Braga. Direito dos Animais: fundamentação e novas perspectivas. Porto Alegre: Sérgio Antônio Fabris, 2008.

MIRANDA, Pontes de. Tratado de direito privado. $4^{\text {a }}$ ed. - São Paulo: Revista dos Tribunais, 1974.

MOLINARO, Carlos Alberto; MEDEIROS, Fernanda Luiza Fontoura de; SARLET, Ingo Wolfgang; FENSTERSEIFER, Tiago [org.] A dignidade da vida e os direitos fundamentais para além dos humanos: uma discussão necessária. Belo Horizonte: Fórum, 2008.

MONTEIRO, Washington de Barros. Curso de Direito Civil. $37^{\mathrm{a}}$ ed., São Paulo: Saraiva, 2000. 
MORAES, Alexandre de. Direito constitucional. 20. ed. - São Paulo: Atlas, 2006.

MORAES, Maria Celina Bodin de. Ampliando os direitos de personalidade. In: Vieira, José Ribas (Org.). 20 anos da Constituição Cidadã de 1988: efetivação ou impasse constitucional? Rio de Janeiro: Forense, 2008.

, Maria Celina Bodin de. Na medida da pessoa humana: estudos de direito civil. - Rio de Janeiro: Renovar, 2010.

Maria Celina Bodin de. O jovem direito civil constitucional. In: revista eletrônica de direito civil. Ano $1 n^{0}$ 1/2012. Disponível em http://civilistica.com/o-jovem-direito-civil-constitucional. Acessado em 12 de janeiro de 2014 às 23:00.

, Maria Celina Bodin de. Danos à pessoa humana: uma leitura civilconstitucional dos danos morais. - Rio de Janeiro: Renovar, 2009.

PAMPLONA FILHO, Rodolfo; ARAÚJO, Ana Thereza Meirelles. Tutela jurídica do nascituro à luz da Constituição Federal. Disponível em: http://www.lex.com.br/doutrina_23883291_NASCITURO_TUTELA_JURIDICA A_LUZ_DA_CONSTITUICAO_FEDERAL.aspx. Acessado em: 28 de janeiro de 2014.

PENNA, Iana Soares de Oliveira. Dignidade da pessoa humana e direito à identidade na redesignação sexual. Orientadora: Caitlin Sampaio Mulholland. Rio de Janeiro - PUC RIO - Departamento de Direito, 2010.

PEREIRA, Caio Mário da Silva. Instituições de Direito Civil: Introdução ao Direito Civil/Teoria Geral de Direito Civil. Vol. I. 25. ed., rev. e atual. por Maria Celina Bodin de Moraes. Rio de Janeiro: Forense, 2012.

PERLINGIERI, Pietro. Perfis do direito civil. Tradução de: Maria Cristina de Cicco. $2^{\mathrm{a}}$ ed. - Rio de Janeiro: Renovar, 2002.

RODRIGUES, Danielle Tetü. O Direito \& os Animais: Uma abordagem Ética, Filosófica e Normativa. 2. ed. Curitiba: Juruá, 2003.

SÁ, NAVES, Maria de Fátima Freire de, Bruno Torquato de Oliveira. Manual de biodireito. $2^{\text {a }}$ ed. - Belo Horizonte: Del Rey, 2011.

SARLET, Ingo Wolfgang. Dignidade da Pessoa Humana e Direitos Fundamentais na Constituição Federal de 1988, $2^{\mathrm{a}}$ ed., Porto Alegre: Livraria do Advogado, 2002.

SAVI, Sérgio. Responsabilidade civil por perda de uma chance. $3^{a}$ ed. São Paulo: Atlas, 2012.

SEMIÃO, Sérgio Abdalla. Os direitos do nascituro: aspectos cíveis, criminais e do biodireito. - $2^{\text {a }}$ ed., ver., atual., e ampl. - Belo Horizonte: Del Rey, 2000. 
SILVA, Gabriela Cristina da. A análise da tutela jurídica do nascituro no ordenamento jurídico brasileiro. 2010. Universidade do Vale do Itajaí. Itajaí, 09 de junho de 2010. Disponível em http://siaibib01.univali.br/pdf/Gabriela\%20Cristina\%20da\%20Silva.pdf.

.Monografia, p. 25. Acessado em: 25 de janeiro de 2013.

SILVA, Romeu Faria Thomé da. Manual de Direito Ambiental. Salvador, Bahia: JusPODIVM, 2011.

SIRVINSKAS, Luís Paulo. Manual de Direito Ambiental. 5. ed., rev. e atual. São Paulo: Saraiva, 2007.

SCHREIBER, Anderson. Novos paradigmas da responsabilidade civil: da erosão dos filtros da reparação à diluição dos danos. - 5. ed. - São Paulo: Atlas, 2013.

STOCO, Rui. Tratado de Responsabilidade Civil. Doutrina e Jurisprudência. $7^{\mathrm{a}}$ ed. São Paulo: Revista dos Tribunais, 2007.

TARTUCE, Flávio. A situação jurídica do nascituro: uma página a ser virada no Direito Brasileiro. In: Questões controvertidas do código civil. Parte Geral. Mário Luiz Delgado e Jones Figueiredo Alves (Coords.). São Paulo: Método, 2007.

TEPEDINO, Gustavo. A tutela da personalidade no ordenamento civilconstitucional. In: Temas de Direito Civil. $3^{a}$ edição atualizada. - Rio de Janeiro: Renovar, 2004.

Gustavo. A parte geral do novo código civil: estudos na perspectiva civil-constitucional, Rio de Janeiro: Renovar, 2002, p. XXV.

TOLEDO; WINDT e CÉSPEDES. Vade Mecum. Obra coletiva de autoria da Editora Saraiva com colaboração de Antônio Luiz de Toledo Pinto, Márcia Cristina Vaz dos Santos Windt e Livia Céspedes. 7. ed. atual. e ampl. São Paulo: Saraiva, 2009.

VELOSO, Maria Cristina Brugnara. A condição animal: uma aporia moderna. Dissertação (Mestrado). Pontifícia Universidade Católica de Minas Gerais. Programa de Pós-Graduação em Direito. Belo Horizonte, 2011.

VENOSA, Silvio de Salvo. Direito Civil. 8 ed. São Paulo: Atlas, 2008.

Silvio de Salvo. Direito civil: direito de família. São Paulo: Atlas, 2009.

ZAINAGHI, Maria Cristina. Os meios de defesa dos direitos do nascituro. São Paulo: LTr, 2007. 